\title{
Classical and Jazz Influences in the Music of Nikolai Kapustin: Piano Sonata No. 3, Op. 55
}

Yana Tyulkova

Follow this and additional works at: https://researchrepository.wvu.edu/etd

\section{Recommended Citation}

Tyulkova, Yana, "Classical and Jazz Influences in the Music of Nikolai Kapustin: Piano Sonata No. 3, Op. 55" (2015). Graduate Theses, Dissertations, and Problem Reports. 6845.

https://researchrepository.wvu.edu/etd/6845

This Dissertation is protected by copyright and/or related rights. It has been brought to you by the The Research Repository @ WVU with permission from the rights-holder(s). You are free to use this Dissertation in any way that is permitted by the copyright and related rights legislation that applies to your use. For other uses you must obtain permission from the rights-holder(s) directly, unless additional rights are indicated by a Creative Commons license in the record and/ or on the work itself. This Dissertation has been accepted for inclusion in WVU Graduate Theses, Dissertations, and Problem Reports collection by an authorized administrator of The Research Repository @ WVU.

For more information, please contact researchrepository@mail.wvu.edu. 
Classical and Jazz Influences in the Music of Nikolai Kapustin: Piano Sonata No. 3, Op. 55

$$
\text { Yana Tyulkova }
$$

\section{A Doctoral Research Project submitted to the College of Creative Arts at West Virginia University}

in partial fulfillment of the requirements for the degree of

Doctor of Musical Arts in

Piano Performance

Peter Amstutz, D.M.A.

William Haller, D.M.A.

Keith Jackson, D.M.A.

James Miltenberger, D.M.A., Committee Chair, Research Advisor

Bernie Schultz, Ph.D.

School of Music

Morgantown, West Virginia 2015

Keywords: Nikolai Kapustin, Piano Sonata, jazz piano, twentieth century piano works Copyright 2015 Yana Tyulkova 


\begin{abstract}
Classical and Jazz Influences in the Music of Nikolai Kapustin: Piano Sonata No. 3, Op. 55 Yana Tyulkova
\end{abstract}

The subject of this dissertation is the contemporary Russian composer and pianist Nikolai Kapustin. Being himself a virtuoso pianist, Kapustin has written a large repertoire for solo piano. During the last fifteen years, the popularity of Kapustin in the United States has grown enormously through performances, publications, presentations, and recordings. Kapustin's output has over 150 opus numbers in all major forms of Baroque, Classical and Romantic music, such as suite, invention, preludes and fugues, variations, sonata, concerto, and more.

Kapustin's style fuses the classical approach to form and the jazz approach to harmony and rhythm in a very unique way. His compositional style is strongly influenced by American jazz, particularly the style of Oscar Peterson, Art Tatum, Herbie Hancock, and Bill Evans. From the other side, his music is strongly influenced by composers of Classical music such as Alexander Scriabin, Sergei Rachmaninov, Frederick Chopin, Maurice Ravel, and Bela Bartok.

Kapustin composed twenty Piano Sonatas during the period of 1984-2011. There has been little research to this point regarding the music of Kapustin and no formal research has been completed concerning Piano Sonata No. 3. This sonata is the particular scope of this dissertation, as nearly every aspect of Kapustin's compositional style can be found in this work.

Sonata No. 3 was composed in 1990 and was published in August 2014. The Sonata is a one-movement work and it contains a quote of the "Dies Irae" theme, which sets this work apart from his other sonatas.

This dissertation will provide biographical information on Nikolai Kapustin, historical and musical background, and will include an analysis of Piano Sonata No. 3.

Fortunately, the author speaks the Russian language and had opportunities to meet with Nikolai Kapustin. The information obtained in personal interviews with the composer will also be presented.

Hopefully, this dissertation will promote further research, performance, and understanding of the music of one of the most outstanding modern day composers, Nikolai Grigorievich Kapustin. 


\section{Acknowledgement}

First, I would like to thank Nikolai Kapustin and Alla Kapustina. I would never imagine that meeting with these two people would ever be possible. Thank you for sharing the information about your life and your music with me! Thank you for the performance and interpretation suggestions. Thank you for your friendship which I hope will last forever.

I would like to sincerely thank Dr. James Miltenberger, my piano teacher (my "Guru"), dissertation advisor, and the chair of my committee for priceless suggestions and advice, for perfect organization of the process of writing the dissertation, and a tremendous amount of help and inspiration. Thank you for developing me as a classical and jazz pianist. This opens new horizons of my musical understanding.

This research would not be possible without my husband Curtis Johnson and my brother Kirill Tyulkov. Thank you for endless corrections of my writing and being patient with me. Thank you for your love and care.

I also would like to thank the members of my Doctoral committee: Dr. Amstutz, Dr. Jackson, Dr. Haller, and Dr. Schultz. Thank you for your support and belief in my ability.

Finally, I would like to thank my parents, Nataly Tyulkova and Anatoly Tyulkov, for their love and deep belief in me! 
Acknowledgement..................................................... i

List of Musical Examples....................................................... iii

List of Charts................................................................

Chapter I - Introduction.................................................... 1

Chapter II - Review of Related Literature....................................... 3

Chapter III - Biography.................................................. 10

Chapter IV - Overview of Musical Style / Influences............................... 22

Chapter V - Overview of Twenty Piano Sonatas................................. 31

Chapter VI - Analysis of Piano Sonata No. 3, Op. 55................................... 39

Chapter VII - Summary and Conclusion..................................... 70

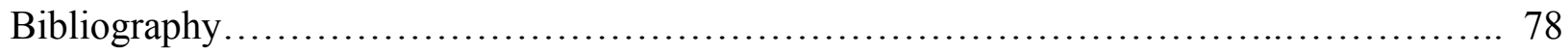

Appendix A: Charts......................................................... 81

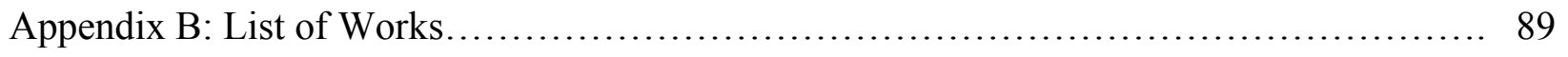




\section{List of Musical Examples}

Example 1: Part I Exposition, Theme A1, m. 1.................................... 43

Example 2: Part I Exposition, Theme A2, mm. 21-22............................ 44

Example 3: Part I Exposition, Theme A3, mm. 31-32 ........................... 45

Example 4: Part I Exposition, Theme A3, Eb blues idea, mm. 34-37.................... 46

Example 5: Part I Exposition, Theme B, mm. 43-44...................................... 46

Example 6: Part I Exposition, "Dies Irae" theme, mm. 60-61..................... 47

Example 7.1: Part I Development, mm. 89-91.................................. 48

Example 7.2: Part I Development, inverted texture, mm. 108-110................... 49

Example 8: Part I Recapitulation, Theme C, mm. 139-141 ....................... 50

Example 9.1: Part II, Theme C, inversion, mm. 161-164............................ 53

Example 9.2: Part II, Theme C, inversion and stretto, mm. 165-168................... 54

Example 10: Part III Exposition, Theme C, mm. 201-202........................ 56

Example 11.1: Part III Exposition, Theme D, mm. 216.2-220...................... 57

Example 11.2: Part III Exposition, Theme D, Count Basie style, mm. 228.3-232.......... 58

Example 12.1: Part III Development, Theme C, canon, mm. 251.2-253................ 59

Example 12.2: Part III Development, Theme A1, pedal point, mm. 255.2-259............. 60

Example 13: Part III Development, Theme C, 12-tone row, mm. 296-298................. 61

Example 14: Part III Development, Theme C, inversion and stretto, mm. 307.3-309........ 62

Example 15.1: Part III Development, Theme C, mm. 314.4-316.2 .................... 63

Example 15.2: Part III Development, Theme C, mm. 314.4-316.2 .................... 63

Example 16.1: Part III, Coda, mm. $385.4-387 \ldots \ldots \ldots \ldots \ldots \ldots \ldots \ldots \ldots \ldots \ldots \ldots \ldots \ldots \ldots . . \ldots 6$

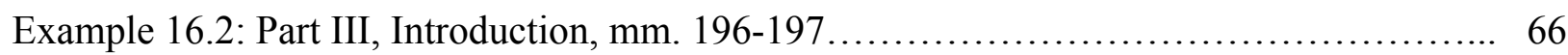


Example 17.1: Part III Exposition, Theme C, fingering, mm. 210-211................. 68

Example 17.2: Part III Exposition, Theme C, fingering, mm. 214-215.................. 69 


\section{List of Charts}

Chart 1: Twenty Piano Sonatas - General Information......................... 32, 81

Chart 2: Twenty Piano Sonatas - Detailed Information......................... 38, 82

Chart 3: Three Parts of Piano Sonata No. 3 ...................................... 40, 83

Chart 4: Piano Sonata No. 3 Part I - Form................................... 41, 83

Chart 5: Piano Sonata No. 3 Part II - Form ................................... 52, 84

Chart 6: Piano Sonata No. 3 Part III - Form.................................... 55, 85

Chart 7: Piano Sonata No. 3 Part I - Texture, Rhythm, Tonality, and Tempo Changes....... 86

Chart 8: Piano Sonata No. 3 Part II - Texture, Rhythm, Tonality, and Tempo Changes..... 87

Chart 9: Piano Sonata No. 3 Part III - Texture, Rhythm, Tonality, and Tempo Changes..... 88 


\section{Chapter I}

\section{Introduction}

The topic of this research is the contemporary Russian composer and pianist Nikolai Kapustin. This paper will focus on the influences from both Classical and Jazz music on his piano style. The particular scope of this research is Piano Sonata No. 3, as nearly every aspect of Kapustin's compositional style can be found in this work. The purpose of this study is to develop interest in Kapustin's piano music through the study of a specific piano work. Hopefully, the study will promote further research, performance, and understanding of the music of one of the most outstanding composers of the $21^{\text {st }}$ century.

This research paper consists of seven chapters. In chapter two a review of the related literature written up to the present time on the music of Nikolai Kapustin will be discussed. It is divided into the Encyclopedias, Dissertations and Theses, Periodicals, and Websites categories. This chapter also consists of the section of Additional Sources with the information gained through interviews with the composer taken during the years of 2013-2015. In chapter three the biography of the composer will be covered. It points out some specific dates and events that influenced and directed Kapustin's career as a composer. In chapter four the overview of Kapustin's musical style will be presented as well as important influences from classical music, American jazz music, and Russian classical music. In chapter five the twenty piano sonatas will be discussed. This chapter contains the general information on the sonatas and gives an overview of the musical style of the sonatas. In chapter six the Piano Sonata No. 3 Op. 55 will be examined. It consists of form and style analysis and general performance suggestions for the interpretation. In chapter seven the summary and conclusion will be covered. This chapter contains the summary of the most important ideas of the paper and draws conclusions. 
Russian contemporary composer and pianist Nikolai Kapustin has written a large number of compositions for solo piano, piano and orchestra, and chamber music. Kapustin's output has over 150 opus numbers. He has written in many genres and uses forms from the Baroque, Classical and Romantic periods: "There are almost 100 Kapustin compositions, in the major forms of the Western musical tradition: concertos, sonatas, chamber and instrumental music."

Being himself a virtuoso pianist, Kapustin's music is concentrated mostly on compositions written for the piano. He has written twenty piano sonatas, six concertos for piano and orchestra, four sets of variations, two suites, and numerous inventions, etudes, preludes, bagatelles, impromptus, nocturnes, and more. ${ }^{2}$ During the last fifteen years, the popularity of Kapustin's music in the United States has grown enormously through performances, publications, presentations, and recordings.

It is interesting to note that starting from the 1990's the composer's productivity increased dramatically. In comparison to the 1980 's, where 25 compositions were written, the 1990's saw an output of 43 compositions, and the 2000's have 58 works composed to the present time. ${ }^{3}$ However, pieces composed specifically for solo piano represent only half of Kapustin's output. The other half consists of pieces for piano and orchestra and piano in chamber music. Hopefully, that part of his music, which remains unknown, will be seriously investigated in the near future. In any case, these numbers are very impressive. Even after fifty-five years' experience in composing very fascinating music, he is still productive to this day.

\footnotetext{
${ }^{1}$ Martin Anderson, “Nikolai Kapustin, Russian Composer of Classical Jazz,” Fanfare 24, no. 11 (September/October 2000): 93.

${ }^{2}$ Wim de Haan, "Nikolai Kapustin: Pianist and Composer," accessed June 20, 2014, http://www.nikolaikapustin.info.

${ }^{3}$ De Haan, "Nikolai Kapustin,” accessed June 21, 2014.
} 


\section{Chapter Two \\ Review of Related Literature}

Very little literature exists regarding the music of Nikolai Kapustin: "The bibliography in English on Kapustin is scant, and to some extent interdependent, since much that is known of him has been derived from a small number of translator-assisted interviews." 4

There are two reasons for the lack of literature. First, the interest in Kapustin's music started to appear only ten to fifteen years ago, and second, Kapustin is not the kind of composer who is seeking popularity. He said: “To be famous isn't important. I don't want to become famous." Kapustin does not like to give interviews as they take the time away from his composition. He wishes to focus his energy only on composition. ${ }^{6}$

At this time, no sources have been found concerning Kapustin's Piano Sonata No. 3 Op. 55. For that reason, the bibliography presented will consist of sources which are related to the investigated topic since many of Kapustin’s piano compositions share similar stylistic features and compositional procedures.

The related literature can be divided into four major categories: Encyclopedias, Dissertations and Theses, Periodicals, and Websites.

The first category, Encyclopedias, mainly contains general information on Nikolai Kapustin. Alla Grigor’yeva’s article “Kapustin, Nikolai Girshevich” in the Oxford Music Online contains brief biographical information and a description of Kapustin's compositional style. However, this article contains a slight error. At Kapustin's debut performance at the $6^{\text {th }}$ World

\footnotetext{
${ }^{4}$ Leslie De'Ath, “Nikolai Kapustin - A Performer's Perspective,” MusicWeb International (June 2002), http://www.musicweb-international.com/classRev/2002/Jun02/Kapustin.htm (accessed June 20, 2014).

${ }^{5}$ Anderson, "Nikolai Kapustin," 97.

${ }^{6}$ Nikolai Kapustin, interview by author, Moscow, December 27, 2013.
} 
Festival of Youth and Students in Moscow in 1957, Kapustin performed his Concertino for Piano and Orchestra Op. 1, not the Concerto for Piano and Orchestra, which is Op. 2.

Famous Russian musicologist and theorist Vladimir Feiertag (whom I personally met in February 2007), wrote an encyclopedic guide Jazz of 20th Century. The second edition of this work appeared in 2008. Among the legendary musicians of the jazz world presented in that book was the composer / pianist Nikolai Kapustin. Interestingly enough, both editions of the encyclopedic guide mention a "Teaching Aid (manual) for Jazz Piano" written by Nikolai Kapustin. This source is cited in both editions of the encyclopedic guide. According to the composer, this "Teaching Aid for Jazz Piano" does not exist. ${ }^{7}$

There are a number of dissertations which directly relate to the music of Nikolai Kapustin. Jonathan Edward Mann, the grandson of famous American musicologist Dr. Alfred Mann, was one of the first scholars who drew special attention to the music of Kapustin in the United States. His dissertation "Red, White, and Blue Notes: The Symbiotic Music of Nikolai Kapustin," written in 2007, was one of the first serious theses concerning the Russian composer. Mann's dissertation investigates Kapustin's musical background and his placement in Russian Soviet jazz. The main body of the work is dedicated to the analyses of three piano works: Sonatina Op. 100, Prelude No. 9 in E Major Op. 53, and Fugue No. 1 in C Major Op. 82.

The dissertation by Randall J. Creighton "A Man of Two Worlds: Classical and Jazz Influences in Nikolai Kapustin's Twenty-Four Preludes, Op. 53" was written in 2009. The work provides an investigation into the traditional jazz techniques as well as more modern jazz stylistic techniques in the Twenty-Four Preludes Op. 53. It also talks about notation of jazz style and includes some suggestions for performers.

\footnotetext{
${ }^{7}$ Nikolai Kapustin, e-mail message to author, August 22, 2014.
} 
Another interesting source of material can be found in the dissertation by Susannah Steele “Nikolai Kapustin's Ten Bagatelles, Op. 59," which was written in 2013. The set of Ten Bagatelles was composed in 1991, just a year after Piano Sonata No. 3, Op. 55. It also remains unknown to the general audience of Kapustin's works. Steele's dissertation observes in detail structural and stylistic features of the Ten Bagatelles. It also has a discussion of technical and musical issues regarding performance. This alone sets this dissertation apart from others that are dedicated only to theoretical analysis.

Jonathan Eugene Roberts' dissertation “Classical Jazz: The Life and Musical Innovations in the Music of Nikolai Kapustin" was also written in 2013. It includes an overview of the history of classical-jazz fusion trends and explains how Kapustin stands apart from the "Third Stream" composers. It also has an overview of Kapustin's compositional technique and the analysis of two pieces: the well-known Piano Sonata No. 2, Op. 54 and Prelude and Fugue, Op. 82 , No. 10. Roberts gives very detailed historical background information about the development of jazz in Russia beginning with the October Revolution in 1917.

Jonathan Roberts stated in this dissertation that "Oleg Lundstrem Big Band is one of the oldest jazz orchestras in the world" because this band existed since $1934 .{ }^{8}$ This is a highly questionable statement. The fact is, there were orchestras in the US as early as 1920's, for example, Paul Whiteman or Fletcher Henderson's Orchestras. Even in Russia there was Alexander Tsfasman's Jazz Orchestra in the late 1920's. Roberts gathered this information from the Oleg Lundstrem official website. However, the original statement sounds different: "The

\footnotetext{
8 Jonathan Roberts, "Classical Jazz: The Life and Musical Innovations of Nikolai Kapustin,” (D.M.A. diss., The University of Alabama, 2013), 21, http://search.proquest.com/docview/1448872255?accountid=2837.
} 
State Jazz Music Chamber Orchestra of Oleg Lundstrem has a unique history. It is the most 'Long Playing' Big Band in the world."'

The latest dissertation on Nikolai Kapustin was written in 2014 from the University of South Carolina by Ruby Wang. This is a discussion of Kapustin's "Eight Concert Etudes," Op. 40 and "Five Etudes in Different Intervals," Op. 68. Ruby Wang investigates the fusion of classical virtuosity and formal structure with the jazz idioms within the Russian pianistic tradition in the etudes of Nikolai Kapustin. Wang discusses the contribution of Kapustin's piano etudes to the existing piano etude repertoire and encourages further study and performance of Kapustin's piano music.

This category, Dissertations and Theses, also includes research material which indirectly includes Nikolai Kapustin. Tetyana Ursova’s dissertation "Interpreting Cycles of Preludes and Fugues by Soviet Composers: Problems of Performance and Perception" was written in 2009 in London. ${ }^{10}$ Ursova's dissertation focuses on the performance aspects of the cycles of Preludes and Fugues written by composers from the former Soviet Union in the post 1950's period. Special attention is drawn to the analytical process and the development of interpretation through the various stages of the learning process. Eight cycles by Russian and Ukranian composers are presented. Among them are Dmitry Shostakovich, Rodion Shedrin, Sergei Slonimsky, and Nikolai Kapustin.

Annalee Schultz Whitehead’s dissertation “A Global Sampling of Piano Music from 1978 to 2005: A Recording Project" was written in 2011. It centered on the major genres in the piano repertoire of the second half of the $20^{\text {th }}$ century. Among represented composers are Lowell Liebermann, Frederic Rzewski, Richard Danielpour, and Nikolai Kapustin.

\footnotetext{
9 “Oleg Lundstrem Jazz Orchestra,” accessed October 14, 2014, http://www.lundstrem-jazz.ru/eng/history.php.

${ }^{10}$ This dissertation is available through the British Library Electronic Theses Online Service EThOS.
} 
Eun-Joung Kim’s dissertation “A Style and Performance Guide to Selected Piano Toccatas, 1957-2000" was written in 2013. In this dissertation Nikolai Kapustin's “Toccatina" Op. 40, No. 3 is presented along with contemporary composers of the second half of the twentieth century, such as Robert Muczynski, Sofia Gubaidulina, York Bowen, and Emma Lou Diemer.

The category Journals includes articles in periodicals that were written in the United States, England, and Russia. Two American journals, Fanfare and Piano Quarterly, have published interviews with Kapustin.

Martin Anderson's interview with Kapustin in the journal Fanfare, "Nikolai Kapustin, Russian Composer of Classical Jazz," was one of the first examples of international interest in Kapustin's music. The interview took place in London during Kapustin's trip to England in May 2000. Kapustin talks about his educational background in music, about the jazz tradition in the Soviet Union, and about the coexistence of classical and jazz styles in his music.

During the same year, another interview with the composer appears in the journal Piano: International Piano Quarterly by Harriet Smith called "Bridging the Divide: The Russian Composer Nikolai Kapustin.” Harriet Smith discusses Kapustin's education and influences from both classical and jazz music. Smith also compares Kapustin's music with the music of Chopin, Bach, Shostakovich, and Stravinsky. ${ }^{11}$

Leslie De'Ath's article "Nikolai Kapustin - A Performer's Perspective" appeared in the MusicWeb International in 2002. This website is one of the largest non-commercial musical resources in England. De'Ath presented Kapustin's music as a part of the "Third Stream," the

\footnotetext{
${ }^{11}$ Harriet Smith, "Bridging the Divide: The Russian Composer Nikolai Kapustin," International Piano Quarterly 4 , no. 13 (Autumn 2000): 54-55.
} 
trend of the latter $20^{\text {th }}$ century music. ${ }^{12}$ De'Ath discussed classical and jazz pianists' approach to performance. He compared Kapustin's music to the etude genre since both demand virtuosic technique. De'Ath also interviewed the composer and in this article included a discussion about the set of "Twenty-Four Preludes and Fugues," Op. 82, as one of Kapustin's most ambitious works. At the end of the article De'Ath made an interesting statement about Kapustin's musical style: "he resists easy classification, he 'belongs' nowhere."13

Two Russian journals, Muzikalnaya jizn [Musical life] and Molodoi uchionii [Young scholar] also published interviews with the composer beginning in 2008.

The Moscow journal Muzikalnaya jizn is a part of the leading Russian music publisher, Publishing House Kompozitor [Composer]. ${ }^{14}$ Established in 1957, this company has been publishing musical scores, books on music, and musical periodicals. Maga Antonina's article "Vse moi proizvedenia - s dzazovym akcentom: Beseda" [All of my work is marked with a jazz emphasis': A conversation] was published in the journal Muzikalnaya jizn in October 2008. Antonina talks with Kapustin about the dualism of Kapustin's music. Antonina compared Kapustin's influences from the Russian classical school, the piano music of Tchaikovsky, Rachmaninov, and Skriabin, as well as the influences from the jazz world, the influence of Oscar Peterson and Friedrich Gulda. Nikolai Kapustin talks about his connections to the music of Gulda, Gershwin, Milhaud, and Ravel. The conversation goes through significant moments of Kapustin's biography. At the end, Kapustin talks about the classical pianists who promote his music, performing his compositions all over the world.

Iskander Gafarov’s article "Nikolai Kapustin. Shtrihi k portretu” [Nikolai Kapustin. Touches to the Portrait] is published in the journal Molodoi uchionii in 2013. This journal was

\footnotetext{
${ }^{12}$ De’Ath, "Nikolai Kapustin."

${ }^{13}$ Ibid.

14 “Kompozitor," accessed September 21, 2014, https://ikompozitor.ru/EN.
} 
established in 2008 and exists in Russian, English, German, and French languages. ${ }^{15}$ Gafarov gives some biographical information on Kapustin as well as an overview of the Soviet jazz music of the 1920's through the 1950's. He stresses the importance of the performance of Kapustin's Concertino for Piano and Orchestra, Op. 1 at the $6^{\text {th }}$ Festival of Youth and Students in Moscow. Later in the article, Gafarov gives an overview of Kapustin's compositional output by decades beginning with the early 1960 's.

Kapustin's official website "Nikolai Kapustin: Pianist and Composer" is maintained by Wim de Haan. This site can be seen as one of the major sources of information on Nikolai Kapustin. It includes a biography, discography, and provides audio and video sources for released and unreleased material of Nikolai Kapustin. It has a general overview of works written by Kapustin. In addition, a forum and guestbook section gives an opportunity to exchange ideas and opinions on the music of Nikolai Kapustin.

The Internet Edition "Nikolai Kapustin," compiled by Onno van Rijen, consists mainly of general information on the composer, articles, and a detailed list of works. It also has reviews of the CD recorded by Steven Osborne on the British label Hyperion Records in 2000. All compositions from that $\mathrm{CD}$ are written by Nikolai Kapustin: Piano Sonata No. 1 "SonataFantasia” Op. 39, Piano Sonata No. 2 Op. 54, and Preludes in Jazz Style Op. 53.

This concludes the review of related literature on the music of Nikolai Kapustin.

\footnotetext{
${ }^{15}$ Journal Molodoi uchionii, ISSN: 2072-0297.
} 


\section{Chapter Three}

\section{Biography}

Nikolai Grigorievich Kapustin was born on November 22, 1937 in the small city of Horlivka, which is situated in the Donetsk province of Eastern Ukraine.

His parents, Grigory Efimovich Kapustin and Klavdia Nikolaevna Kapustina, were not musicians but they loved music and dreamed of seeing their children, Nikolai and older sister Fira, become musicians. ${ }^{16}$ That is why music was always a part of their lives. Only their son Nikolai made these dreams come true, as his sister became a chemist.

At the beginning of the 1940's Ukraine was one of the countries that were occupied by German forces. At the age of four Nikolai with his mother, sister, and grand-mother were evacuated to the Kyrgyz Republic region to stay away from the hostilities. Kyrgyz Republic borders with Kazakhstan, Uzbekistan, Tajikistan and China. During the following two years, 1941-1943, they lived in the small city of Tokmak. At the same time Nikolai's father served as part of the troops at the front. He came back home at the end of World War II, in the summer of $1945 .^{17}$

Nikolai made his first steps in music not in the traditional Russian way. At age seven he began his journey through the world of piano music having private lessons with Piotr Ivanovich Vinnichenko, who was a violinist but also taught piano. Since Fira was taking violin lessons with Piotr Vinnichenko, Nikolai started to take piano lessons with the same teacher. ${ }^{18}$

Traditionally, Russian and Ukrainian musical education is based on three major components that each student must complete during their musical study. These components are: Music School (seven years of study), Music College (four years of study), and Conservatory

\footnotetext{
${ }^{16}$ Roberts, "Classical Jazz,” 15.

${ }^{17}$ Nikolai Kapustin, interview by author, July 9, 2014.

18 Roberts, 15.
} 
(five years of study). This system remains standard for Russian and Ukrainian musical education to this day. In a non-traditional way, Kapustin jumped through the first step of his musical education as he did not attend music school.

Listening to a seven-year-old Nikolai playing Clementi Sonatinas, Op. 36, Piotr Vinnichenko realized that Nikolai needed serious training on the piano since the child had huge potential as a pianist. The lessons with Vinnichenko lasted until 1949. At that time Nikolai Kapustin began piano lessons with, as Vinnichenko stated, a "real" piano teacher. Lubov' Frantsuzova had graduated from the Saint-Petersburg Conservatory and studied with Samuel Maykapar, one of the major figures in Russian musical education. ${ }^{19}$ During the next three years, Lubov' Frantsuzova worked to prepare Nikolai Kapustin for the entrance exam to the Academic Moscow College under the Moscow State Tchaikovsky Conservatory.

Kapustin remembers very clearly the moment he came to Moscow with his first teacher Piotr Vinnichenko: "The fact is that we came to Moscow with only one goal - to play the entrance exam to Moscow Music College. That's what I did. ${ }^{20}$ Without knowing anyone Kapustin was immediately accepted into the class of Avrelian Grigoryevich Rubakh. Rubakh came to play a major role in the life of Nikolai Kapustin.

Avrelian Rubakh was a student of Felix Blumenfeld, who was the teacher of Vladimir Horovitz and Simon Barere. ${ }^{21}$ In addition, Alexander Tsfasman, one of the first famous jazz pianists in Russia during the 1940's, was also a student of Blumenfeld. All four of these pianists, Blumenfeld, Tsfasman, Horovitz, and Kapustin, were born in the Ukraine.

\footnotetext{
${ }^{19}$ Jonathan Mann, "Red, White and Blue Notes: The Symbiotic Music of Nikolai Kapustin," (D.M.A. diss., University of Cincinnati, 2007), 28, http://search.proquest.com/docview/304883419?accountid=2837.

${ }^{20}$ Nikolai Kapustin, e-mail message to author, August 27, 2014.

${ }^{21}$ Mann, "Red, White and Blue Notes," 28.
} 
In the 1950's Avrelian Grigoryevich Rubakh was teaching at the Special Music School for Talented Children under the Moscow Conservatory and at the same time at the Academic Music College under the Moscow Conservatory. ${ }^{22}$ That is probably why, listening to a 14 -year old Nikolai Kapustin, he noticed big talent in the young performer.

Kapustin says that at that time he was not a strong pianist, but what Rubakh saw in him was the ability to compose music. ${ }^{23}$ Indeed, at a very early age Kapustin became interested in improvisation and composition. At the age of 13 years he composed his first piano sonata. This piece is written in the traditional classical style. During all these years the score of the piano sonata remains in the possession of Nikolai Kapustin in his home. ${ }^{24}$

Avrelian Rubakh was a teacher with a variety of different interests and activities which were all connected to the teaching process. He was the editor of the Muzgiz Publisher (Soviet Music Publishing House) in Moscow. He was also the editor of Anthologies of Pedagogic Repertoire for Music Schools, which were published with pedagogical suggestions for teachers. Finally, he was writing arrangements of orchestral works. For example, Tchaikovsky's Orchestral Suite No. 1, Op. 43 was arranged by Rubakh for two pianos and published in 1956.

As a teacher Avrelian Rubakh showed a wide range of interests in different musical styles. One of his students, Evgeniya Pupkova, born in 1938, became one of the famous performers of J. S. Bach's works. Pupkova remembered Rubakh's critical notes about her performance of J. S. Bach's fugue: "How do you want me to hear four voices, when out of four you hear only two?"25

\footnotetext{
${ }^{22}$ Evgeniya Pupkova, "Pereigravshaya vsego Baha," accessed August 30, 2014, http://pupkova.ru/biography.html.

${ }^{23}$ Nikolai Kapustin, e-mail message to author, August 22, 2014.

${ }^{24}$ Nikolai Kapustin, skype conversation with the author, March 22, 2015.

${ }^{25}$ Pupkova, "Pereigravshaya vsego Baha."
} 
On the other hand, Avrelian Rubakh was one of the people who supported Nikolai Kapustin's interest in jazz. Kapustin mentioned that the four years he spent around Rubakh (1952-1956) were the most interesting and productive years of his student life. Rubakh was a key figure in Kapustin's life. Kapustin said: "He (Rubakh) taught me how to play the piano.,26

In the year of 1953, an important historical event happened in Russia that changed the direction of Russian history. On March 5, 1953 Iosif ( Joseph) Vissarionovich Stalin died. Stalin was the leader of the Soviet Union from the mid -1920's until his death in 1953. In the postStalin "thaw," more freedom appeared in all aspects of Russian life. Even though jazz was still prohibited, the interest in jazz was growing enormously as a symbol of freedom.

In the interview with Anderson, Kapustin stated about jazz: “ ... in the early 50's it was completely prohibited, and there were articles in our magazines that said it was typical capitalistic culture, so we have to throw it away and forget about it."27

During the years of study in Moscow College Kapustin got acquainted with Andrei Mikhalkov-Konchalovsky. Andrei would become later a well-known Russian-American film director and film producer. ${ }^{28}$ Nikolai and Andrei studied together in Music College and became close friends. Andrei’s father, Sergei Mikhalkov, was a famous Russian author, poet, and dramatist. Since the conditions of Kapustin's life at the dormitory were very poor, Sergei Mikhalkov invited young student Nikolai Kapustin to live in their house. That is how during the years of 1954 and 1955 Kapustin was living in the house of Mikhalkov's family. ${ }^{29}$ It is obvious that the atmosphere of Mikhalkov's house, together with the experience that Kapustin had communicating with the highest level of Russian artistic society, was priceless. This was the time

\footnotetext{
${ }^{26}$ Nikolai Kapustin, interview by author, December 27, 2013.

${ }^{27}$ Anderson, 96.

${ }^{28}$ Andrei Konchalovsky is a film director for "Tango and Cash" (1989) and "The Odyssey" (1997).

${ }^{29}$ Nikolai Kapustin, interview by author, December 27, 2013.
} 
when Kapustin first got acquainted with jazz and discovered a new world of jazz improvisation. He remembers: "I was living in their house for a few years like an adopted son. That's how we first started to become interested in jazz music, listening at night to the radio station "Voice of America. ${ }^{, 30}$ This is where he first heard Louis Armstrong, Glenn Miller, Benny Goodman, and Nat "King" Cole. According to Roberts, Kapustin met Oleg Lundstrem for the first time in this house in $1956{ }^{31}$

During the early 1950's Kapustin began to perform as a jazz pianist. He organized a Jazz Quintet and started to perform monthly in one of the most exclusive Moscow restaurants called "National." Americans visited this restaurant and on one occasion recorded the performance of Kapustin's Jazz Quintet. Eventually, the performance of this band was broadcast on the radio station "Voice of America." That is how the name of Nikolai Kapustin first appeared in the United States. ${ }^{32}$

In the summer of 1956 Nikolai Kapustin graduated from Music College and entered the Moscow Conservatory. Kapustin was accepted to the class of legendary pianist, teacher, composer, and author Alexander Goldenweiser.

Alexander Goldenweiser was a student of Ziloti, Pabst, Arensky, and Ippolitov-Ivanov. ${ }^{33}$ He also studied with Sergei Taneyev (a significant Russian composer, pianist and music theorist), and Vasily Safonov (a famous Russian music educator and conductor, and the teacher of Alexander Scriabin and Nikolai Medtner). In addition to that, Goldenweiser was a classmate of some of the best-known Russian composers. Goldenweiser told his students about the years of

\footnotetext{
${ }^{30}$ Nikolai Kapustin, interview by author, December 27, 2013.

${ }^{31}$ Roberts, 21.

${ }^{32}$ Anderson, 94.

${ }^{33}$ Smith, 54.
} 
study at the Moscow Conservatory: "I was sitting in the lectures together with Alexander Scriabin, Sergei Rachmaninov, and Nikolai Medtner."34

Another interesting fact from Goldenweiser's life was that he was a close friend of Lev (Leo) Nikolaevich Tolstoy, Russian writer, philosopher, and political thinker, who wrote several bestsellers of Russian literature War and Peace (1896) and Anna Karenina (1877). ${ }^{35}$

Goldenweiser was the editor of the Beethoven and Mozart Piano Sonatas, Schumann and Liszt's piano works. ${ }^{36}$ In addition, the fact that Rachmaninov's Suite No. 2, Op. 17 as well as Medtner's Lyric Fragments, Op. 23 were both dedicated to Alexander Goldenweiser supports the importance of Goldenweiser in the development of Russian musical history.

Among the celebrated students of Alexander Goldenweizer were Dmitry Kabalevsky, Tatiyana Nikolaeva, Dmitry Bashkirov, and Nikolai Kapustin.

Kapustin remembered his audition for Alexander Goldenweiser in 1956. Upon hearing Kapustin's performance of Liszt's Reminiscences de Don Juan (one of the most technically difficult works by Liszt) Goldenweiser asked Rubakh: "Where did you find such a pianist?" ${ }^{37}$ Of course, this question was rhetorical, but anyone could see that Goldenweiser was impressed by the level of Rubakh's students' performance.

While Avrelian Rubahk had appreciated jazz in Kapustin's musical environment, Alexander Goldenweiser was associated exclusively with classical music. Kapustin mentioned in our interview that he is not sure if Goldenweiser ever heard the word "jazz."38

It is understandable that Kapustin felt the years he spent in the Music College were more productive and interesting. Although, Kapustin mentioned in the interview with Martin Anderson

\footnotetext{
${ }^{34}$ Pupkova, "Pereigravshaya vsego Baha."

${ }^{35}$ Ivan Fedorov, "Belcanto.ru," accessed September 23, 2014, http://www.belcanto.ru/goldenveiser.html.

${ }^{36}$ Ibid.

${ }^{37}$ Anderson, 94.

${ }^{38}$ Nikolai Kapustin, interview by author, December 27, 2013.
} 
that it was very interesting to speak with Goldenweiser, because Goldenweiser used to tell him about all these famous composers from the past. Kapustin then continued: "But as a teacher he gave nothing, because he was very old - he was already $81 .{ }^{39}$ Nikolai Kapustin was one of Goldenweiser's last students, since Goldenweiser passed away in November of 1961, the year of Kapustin's graduation from the Moscow Conservatory.

While a student of Moscow College and the Moscow Conservatory, Kapustin was trained to be a virtuoso pianist. That was his original goal - to become a virtuoso performer. Undoubtedly Kapustin achieved great results in this direction. He graduated from Moscow College with Prokofiev's Piano Concerto No. 2, Op. 16, one of Prokofiev's most challenging pieces. Kapustin graduated from the Moscow Conservatory with Bartok's Piano Concerto No. 2, an extremely complicated piece of music, difficult technically, and percussive in sound. These performances showed Kapustin's ability as a serious classical pianist who could potentially perform on the big stage. Even now, listening to Kapustin's compositions, it is obvious that his music demands highly technical skills. Unfortunately, through the years, Kapustin began to struggle performing in front of an audience. Later, this feeling would direct him to the complete dedication to composition and rejection of a career as a virtuoso pianist.

During the years of study in the Conservatory in the late 1950's, Kapustin worked as a jazz pianist, arranger, and composer. One of the important landmarks in his career as a composer was his performance in July 1957 of his own piece, Concertino for Piano and Orchestra, Op. 1, in the $6^{\text {th }}$ World Festival of Youth and Students in Moscow. The festival itself was an important event in the history of Russia. It was the time of the "Khrushchev thaw," a period of positive changes towards the direction of "peaceful cooperation" with the Western world. ${ }^{40}$ The festival

\footnotetext{
${ }^{39}$ Anderson, 94.

40 “Territory of Terror," accessed October 15, 2014, http://territoryterror.org.ua/en/history/1953-1964.
} 
opened the doors to other countries and other cultures. It attracted 34,000 young people from 131 countries and became an international event. ${ }^{41}$ Undoubtedly, this festival made an important impact on the young Kapustin. The Concertino for Piano and Orchestra, Op. 1 was composed by Kapustin specifically for the festival and was performed by Kapustin with the Yuri Saulsky Big Band. Kapustin remembers: "That was my first experience playing in a big band and I understood that this is not a bad thing. I started to write for that orchestra." ${ }^{42}$ Concertino for Piano and Orchestra, Op. 1 was the first of Kapustin's piece to be performed in public.

A new period of Kapustin's life started in 1961 when he started to collaborate with the Oleg Lundstrem Big Band. The history of this orchestra goes back to the 1934 when it was organized by a group of friends. ${ }^{43}$ Starting from the late 1950's the band toured extensively inside and outside of the Soviet Union. ${ }^{44}$ Kapustin joined the band at the time of its rise and high success. During the years of 1961 to 1972 Kapustin was writing music for this big band and performing as a pianist. Kapustin mentioned in the interview with Maga Antonina: "Eleven years of work with Lundstrem became my "Second Conservatory": a large amount of arranging, performances, and ear-training experience. We wrote down all the big-band parts from the tape. We were big enthusiasts. It was a school more serious than Conservatory." ${ }^{, 45}$ Then Kapustin continues: "Mostly it was classical jazz - Count Basie, Duke Ellington. Even if we were performing Soviet songs, orchestral accompaniment still was in the style of Count Basie."46

\footnotetext{
41 “Russkii Portal,” accessed January 15, 2015, http://www.opoccuu.com/280711.htm.

${ }^{42}$ Nikolai Kapustin, interview by author, December 27, 2013.

${ }^{43}$ Osip Ivanov, “Oleg Lundstrem Jazz Orchestra,” accessed September 20, 2014, http://www.lundstremjazz.ru/eng/history.php.

${ }^{44}$ Osip Ivanov, "Oleg Lundstrem Jazz Orchestra,” accessed September 21, 2014, http://www.lundstremjazz.ru/eng/history.php.

${ }^{45}$ Maga Antonina, "Vse moi proizvedenia - s dzazovim akcentom: Beseda" [All of my work is marked with a jazz emphasis': A conversation], Muzikalnaya jizn, no. 10 (October 2008): 40.

${ }^{46}$ Ibid.
} 
One of the first works composed specifically for the Oleg Lundstrem Big Band was Kapustin's Piano Concerto No. 1, Op. 2. Unfortunately, this piece was played only five times, probably because the musicians were not prepared for such a serious piece. Being a big band, the group was accustomed to shorter and lighter material. ${ }^{47}$

One of the most impressive pieces of that time was Kapustin's "Toccata," Op. 8.

Recorded by Russian television in 1964, this piece demonstrated the technical ability of Kapustin as well as his talent as a composer. ${ }^{48}$

At the end of 1960's, touring with the Oleg Lundstrem Big Band, Kapustin met his future wife Alla Baranovskaya in the north city of Novokuznetsk, which is situated in Siberia. They were seated at the same table in the café and Kapustin invited Alla to their concert. That's how their friendship began. ${ }^{49}$ In January 1969 Nikolai Kapustin and Alla got married. They have two sons: Anton (born in 1971) and Pavel (born in 1978). The older son, Anton Kapustin, is famous for his pioneering work in non-commutative geometry. For many years Anton has lived in the United States dedicating his life to the world of theoretical physics. Pavel Kapustin lives in Moscow and works as an economist. ${ }^{50}$

Having a family, Kapustin could not allow himself to tour extensively with the Lundstrem Big Band. Therefore, beginning from 1972 Kapustin stated to work with the Boris Karamishev "Blue Screen" Orchestra in Moscow. The function of this orchestra was to broadcast live over television and radio. However, this orchestra also toured in USSR and did recording

\footnotetext{
${ }^{47}$ Nikolai Kapustin, interview by author, December 27, 2013.

${ }^{48}$ Video recording of the "Toccata" Op. 8, accessed September 21, 2014, https://www.youtube.com/watch?v=uemOuoNbUz0.

${ }^{49}$ Roberts, 22.

${ }^{50}$ Nikolai Kapustin, interview by author, December 27, 2013.
} 
sessions. For example, they recorded many works of Soviet composers as well as Kapustin's compositions. $^{51}$

In 1977 Kapustin joined the State Symphonic Orchestra of Cinematography. The function of this orchestra was the recording of music for the cinema. He worked there until $1984 .^{52}$

In 1980 Kapustin performed his Concerto for Piano and Orchestra No. 2, Op. 14 in the Tchaikovsky Concert Hall. After this performance he decided to stop performing in public. However, Kapustin would appear on stage through the late 1990's with his friend cellist Alexander Zagorinsky in Russia and Germany. ${ }^{53}$

Starting from the 1980's Kapustin decided to dedicate himself exclusively to composition. In 1983 the Music Publishing House in Moscow accepted for publication “Toccatina," Op. 36. This was the first piece by Kapustin to be published. ${ }^{54}$

In the interview with Martin Anderson Kapustin stated: "I don't like to play on stage, but I do like to record." ${ }^{55}$ During the period of 1984 to 2007 Kapustin recorded solo albums on a regular basis. Many of these recordings are called "Kapustin plays Kapustin,” produced by Japanese label Triton, and remain unavailable outside of Japan. ${ }^{56}$ At the present time Kapustin performs mostly for his close friends and for family members. His performances are usually highly anticipated. ${ }^{57}$

The major focus of the 1980's shifted from music for piano and orchestra to music written exclusively for the piano. Beginning in 1984, Kapustin began to compose his piano sonatas. Ten of them were completed by the end of 1999.

\footnotetext{
${ }^{51}$ Roberts, 22.

${ }_{53}^{52}$ Roberts, 23.

${ }^{53}$ Ibid.

${ }^{54}$ Ibid.

${ }^{55}$ Anderson, 97.

${ }^{56}$ De'Ath, "Nikolai Kapustin."

${ }^{57}$ Nikolai Kapustin, interview by author, July 9, 2014.
} 
In 2000 Kapustin made his first and only trip to England. Nikolai Kapustin and his wife Alla spent a week in London in May of 2000. It took them three days to get to England by train. Kapustin made this trip to attend the formation of "Kapustin's Piano Society," a group of people who appreciate the music of Nikolai Kapustin, organized by Jan Hoare. He also heard the Western premiere of his Piano Sonata No. 2, Op. 54 by Marc-Andre Hamelin, one of the most respected modern day pianists. Martin Anderson described it this way: "Earlier this year, in May, Hamelin gave the Western premier of the Second Piano Sonata at a "Hamelin weekend" at Blackheath Concert Halls in southeast London, and Kapustin made the journey from Moscow for this occasion. ${ }^{, 58}$

During this visit Kapustin gave a few interviews to the English newspapers. For example, the well-known interviews with Martin Andersons and Leslie De'Ath were recorded at that time. In appreciation for his reception in London, Kapustin composed his Piano Sonata No. 11, Op. 101 dedicated to London. The sonata has the nickname "Twickenham," which is the borough of the southwest area of London.

Russian audiences also appreciate the music of Nikolai Kapustin. The concert dedicated to Kapustin's $70^{\text {th }}$ birthday took place in Gnesina College (Moscow) on December 11, 2007. Chamber music of Nikolai Kapustin was performed in the first part of the concert: Elegy for Cello and Piano, Op. 96, Burlesque for Cello and Piano, Op. 97, Nearly Waltz for Cello and Piano, Op. 98, Sonata for Cello and Piano No. 2, Op. 84, and Trio for Flute, Cello and Piano, Op. 86. In the second part of the concert was orchestral music of Nikolai Kapustin: Concerto No. 2 for Cello and String Orchestra, Op. 103 and Concerto for Violin, Piano and String Orchestra, Op.

\footnotetext{
${ }^{58}$ Anderson, 93.
} 
105. Alexander Zagorinsky performed all the pieces written for cello. Nikolai Kapustin was in the audience. ${ }^{59}$

Two years later, on March 8, 2009, the second concert dedicated to the music of Nikolai Kapustin took place in the Chamber Hall of Moscow Philharmonic Society. Later, on December 18, 2011, the third concert took place in the Arkhipov's Musical Salon in Moscow.

During the last 15 years Kapustin has lived in his Moscow flat with his wife Alla Semionovna Kapustina. He never leaves the flat except to travel every summer to their summer house. By choice he has separated himself from the outside world. Kapustin lives in the world of his music, his own world. I asked Alla Semionovna how often Nikolai Kapustin composes music, she said: "Kolia (a term of endearment for Nikolai) is composing all the time." Alla is his best friend, a person who is taking good care of one of the most talented composers of our time. ${ }^{60}$ Most of the summers they spend in their summer house, which is situated 100 kilometers to the south of Moscow. Even there, Kapustin does not stop the composition process. He keeps saying that perhaps it's time to quit, that the music is not coming as easily as it did before. At the same time he feels joyful about the new material that he has recently composed. Despite the fact that the music does not come as easily as it once did, the author believes that he will never stop composing! This is his destiny.

\footnotetext{
${ }^{59}$ Ivan Fedorov, "ClassicalForum.ru,” accessed September 23, 2014, http://www.classicalforum.ru/index.php?topic=395.0.

${ }^{60}$ Nikolai Kapustin, interview by author, December 27, 2013.
} 


\section{Chapter Four}

\section{Overview of Musical Style / Influences}

Nikolai Kapustin has had no official training in composition or in jazz piano. He is a selftaught composer and a self-taught jazz pianist. In March 2009 in Moscow, during the concert dedicated to the works of Nikolai Kapustin, the composer answered a series of questions from the audience. One of the questions was how it is possible to compose a set of Twenty-Four Preludes and Fugues without formal training in composition. Kapustin's answer surprised the audience: "Nothing special, Bach [J. S. Bach] was also a self-taught composer. This didn’t stop him from composing his preludes and fugues." ${ }^{\prime 61}$

The fact that Kapustin did not have formal training as a composer did not stop him from developing an interest in composition. Iskander Gafarov stated in his article "Nikolai Kapustin. Touches to the Portrait" that Kapustin's strong education in the Moscow College and Conservatory served as the foundation for his further development as a composer. ${ }^{62}$ Indeed, the classes that Kapustin was taking in the years of his study included many different subjects such as orchestration, form and analysis, polyphony, theory, music history, folk art, and others.

In addition, it is worth mentioning Kapustin's thoughts about his education in the interview with Maga Antonina: "I didn't want to study with the composition faculty of Moscow Conservatory because I didn't want any foreign influence to affect my musical style. Who would appreciate my jazz experiments at that time? I would have been expelled." ${ }^{.63}$

While Kapustin didn't study as a jazz pianist he was listening to and transcribing the compositions that he heard on the radio station "Voice of America." Having an excellent ear-

\footnotetext{
${ }^{61}$ Fedorov, "ClassicalForum.ru,” accessed September 23, 2014.

${ }^{62}$ Iskander Gafarov, "Nikolai Kapustin. Shtrihi k portretu," Molodoi uchionii, no. 2 (2013): 445-446, http://www.moluch.ru/archive/49/6252 (accessed September 1, 2014).

63 Antonina, 39.
} 
training and theory background, he was able to study the recordings of Count Basie, Duke Ellington, Nat “King” Cole, Bill Evans, Ella Fitzgerald, and many other performers. In 1961 Kapustin was selected to work as a jazz pianist and composer in the Oleg Lundstrem Orchestra, one of the best jazz orchestras in Russia even to the present day. This is strong evidence of his rapid development as a jazz pianist.

Kapustin's musical style represents the idiomatic fusion of the classical and jazz traditions. The question arises, how to define the music of Nikolai Kapustin? Randall J. Creighton divided composers such as Kapustin into three major categories: classical composers with jazz influence, jazz composers with classical influence, and crossover composers. According to Creighton, Kapustin belongs to the last category. ${ }^{64}$ The next question is which side is more important: classical or jazz? Maybe both styles are represented equally? In the interview with Harriet Smith, Kapustin stated: "For me the classical part is more important. The jazz style is there to give color - I don't like jazz 'forms' - if you describe them as that - which is why I've adopted those from classical music." 65

The idea of fusion, the synthesis of classical and jazz styles, is nothing new. At the beginning of the twentieth century, composers such as Maurice Ravel, Eric Satie, Darius Milhaud, and George Gershwin were already experimenting with the jazz language. Later, some composers from the second part of the Twentieth century such as Claude Bolling and Friedrich Gulda, incorporated the style of jazz pianists in their music. The music of these composers came even closer to what Kapustin is doing at the present time.

\footnotetext{
${ }^{64}$ Randall J. Creighton, "A Man of Two Worlds: Classical and Jazz Influences in Nikolai Kapustin's Twenty-Four Preludes, Op. 53." (D.M.A. diss., The University of Arizona, 2009), 263, http://search.proquest.com/docview/304846309?accountid=2837.

${ }^{65}$ Smith, 54-55.
} 
According to Randall J. Creighton, Kapustin's music is unique and different from other composers because he is not only trying to fuse these two styles together, but also create something new on the foundation of these concepts. Instead of trying to recreate the style of a particular jazz pianist as a whole, Kapustin takes just one aspect of this style and uses it to create something original. The result reminds us of a style of a specific jazz pianist without Kapustin doing an imitation, which is what some other composers do. ${ }^{66}$

In order to trace the Classical influences in the music of Kapustin it is necessary to observe Kapustin's favorite composers beginning from his youth. Kapustin said: "We all grew up on the music of Bach, Mozart, and Beethoven. Later, when I came to Moscow, I became interested in the music of Sergei Prokofiev. Since Rubakh highly respected the music of Prokofiev, I started to play it, beginning with small pieces, then two Piano Concertos. ${ }^{967}$ During the years of study in the Conservatory Kapustin also developed an interest in the music of Ravel and later Bartok. ${ }^{68}$ Kapustin made an interesting comparison between his music and the music of Chopin: "It is pleasant to play my music until the point when you have to increase the tempo. The same thing is true with Chopin's music. For example with etudes, it is pleasant if you do not play too fast. ${ }^{~} 69$

There are three major factors which indicate the influence of Classical music on the music of Kapustin. They are the use of the genres and forms of classical music, the compositional process, and compositional techniques.

\footnotetext{
${ }^{66}$ Creighton, 272.

${ }^{67}$ Nikolai Kapustin, interview by author, December 27, 2013.

${ }^{68}$ Ibid.

${ }^{69}$ Ibid.
} 
Kapustin uses classical genres such as sonata, concerto, symphony, string quartet, piano trio, suite, rhapsody, prelude and fugue, toccata, etude, nocturne, etc. Kapustin also uses classical forms such as variations, sonata-allegro, rondo, binary, ternary, and more.

Kapustin's compositional process is very similar to that of many Classical composers. Kapustin's approach to composition is not to write something spontaneous, but to work with the musical material to improve it, to make it perfect. Kapustin noted: "Beethoven was a great improviser. He could easily write down all his improvisations. Did he do it even once? No, he worked very hard. The notebooks full of sketches prove this statement. At the beginning it was not possible to recognize that this material could become one of his best sonatas. Classical composers understood that after many rewrites the result will be completely different."70

Classical compositional techniques are utilized in his approach to composition. These techniques include thematic transformation, motivic development, and contrapuntal devices such as stretto and inversion.

In addition, the way Kapustin notates his music, much of which exists in manuscripts, shows a more Classical approach. Susannah Steele pointed out that “Kapustin's music has a tendency to over-intellectualize notation, writing jazz chords in a classically academic way that no jazzer would ever do." ${ }^{, 71}$ Most jazz pianists would not notate the chords note by note; the jazz pianists would usually use chord symbols. That is why Kapustin's detailed approach in notating every small detail, precisely checking every note in his published scores, shows his connection more to the classical approach rather than to jazz.

Jazz influences in the music of Kapustin may be traced from many different sources. First of all, his music is much influenced by the playing of some of the greatest and most

\footnotetext{
${ }^{70}$ Nikolai Kapustin, interview by author, December 27, 2013.

${ }^{71}$ Susannah Steele, "Nikolai Kapustin's 'Ten Bagatelles,' Op. 59." (D.M.A. diss., The University of North Carolina at Greensboro, 2013), 44, http://search.proquest.com/docview/1426396425?accountid=2837.
} 
innovative jazz pianists in history such as Oscar Peterson, Art Tatum, McCoy Tyner, Herbie Hancock, Bill Evans, and Lennie Tristano. ${ }^{72}$ An interesting parallel can be made between Bill Evans, and Nikolai Kapustin. Both jazz pianists started their career as classical pianists, and both were much influenced by the music of Maurice Ravel. As a result of this, the influence of Evans can be seen in the music of Kapustin in his treatment of the piano, voicing, and quartal harmonies. Oscar Peterson was also strongly influenced by the music of impressionist composers. Generally speaking, Kapustin's influences did not change much through the years. Even now he continues to explore the style that he heard in his youth, the pianistic style of Oscar Peterson, Art Tatum, and McCoy Tyner.

Second, Kapustin utilizes the styles of swing, rag-time, blues, be-bop, stride, and boogiewoogie in his compositions. At this time, there is no standardized notation of swing. Often questions arise concerning different interpretations of the swing style. In the case of Kapustin's music it is even more complicated. Susannah Steele pointed out that "the composer uses both straight eights and jazz-rock styles, and it can be difficult to identify places in which swing rhythm would be appropriate. ${ }^{, 73}$ It is true that sometimes Kapustin does not indicate in the score whether he wants to have swing or straight eighth-notes. The composer's intention is to leave this choice to the performer. ${ }^{74}$ Kapustin wants us to make the final decision based on our personal feeling of the specific section of the piece. This is an example of the dual nature of Kapustin as a composer. On one hand, he doesn't want us to improvise and make his creation different every time. On the other hand, he does allow us some freedom regarding an approach to the rhythm.

\footnotetext{
${ }^{72}$ Nikolai Kapustin, interview by author, December 27, 2013.

${ }^{73}$ Steele, 47.

${ }^{74}$ Nikolai Kapustin, e-mail to author, October 28, 2014.
} 
Third, the harmonic, rhythmic, and textural complexity of Kapustin's music reflects his influence from jazz music.

Kapustin's music seems to be improvisation in a jazz style. However, all his music is written out. Kapustin doesn't want anyone to improvise even a section in his pieces, since the improvisation itself may consist of some "wrong notes" or not clearly articulated musical ideas. ${ }^{75}$ He said: "There is no need to improvise with my music, although it is jazz.... I am not interested in improvisation - and what is a jazz musician without improvisation? But I am not interested, because it's not perfect." ${ }^{, 76}$

In the interview with Martin Anderson Kapustin said: "You can take anything, but you take it into your own tradition." ${ }^{, 77}$ This statement connects Kapustin's music with Russian tradition, the music of Scriabin, Rachmaninov, and Medtner. The composer stated that his music has "Russian intonations, with something of the nature of Russia in it, a deeper quality." 78 Indeed, Kapustin uses Russian motives in his music. He was surprised when he read in an article that his set of "Variations," Op. 41 is based on Stravinsky's famous motive from the opening of “The Rite of Spring." According to the composer, he simply used a Russian motive without recalling Stravinsky's theme. ${ }^{79}$

Another substantial characteristic of Kapustin's musical language is the frequent change of tonal centers. Sometimes he modulates so often that it is hard to comprehend what key we are in. Also, Kapustin occasionally uses the idea of the twelve-tone row, which shows his awareness of serial technique ${ }^{80}$ However, Susannah Steele points out that on a large scale "the chromatic,

\footnotetext{
${ }^{75}$ Nikolai Kapustin, interview by author, December 27, 2013.

${ }^{76}$ Anderson, 96.

${ }^{77}$ Ibid.

${ }^{78}$ Ibid.

${ }^{79}$ Nikolai Kapustin, e-mail to author, April 19, 2014.

${ }^{80}$ Steele, 33.
} 
'faux dodecaphonic' passages make appearances in the music but they are only moments coloring an otherwise tonal whole. ${ }^{.81}$

Looking at the entire output of compositions by Kapustin, the genres emphasized vary from one decade to the next. For the most part, Kapustin's creative output reflects the general focus of his life or official work during each decade. For example, in the 1960's he was writing music for the big band. At this time Kapustin was working as a jazz pianist and composer in the Oleg Lundstrem Big Band. Music of that period included Concerto for Piano and Orchestra No. 1, Op. 2, Toccata for Piano and Orchestra, Op. 8, and Aquarium-Blues for the Big Band, Op. 12, specifically composed for the Lundstrem Big Band.

The music of the 1970's was inspired by the Hollywood movies of the 1940's. During that time Kapustin was working with the Boris Karamishev "Blue Screen" Television and Radio Orchestra and State Symphonic Orchestra of Cinematography. It is clear that the State Symphonic Orchestra was recording the music for movies, many of which were much influenced by the American cinema. During that period, Kapustin composed Concerto for Piano and Orchestra No. 2, Op. 14, The Forest Story for Orchestra, Op. 15, and Enigma for Big Band, Op. 23.

Beginning in the 1980 's, Kapustin began writing primarily piano music. This was a result of his resignation in 1984 from his position as a pianist for the State Symphonic Orchestra of Cinematography. Piano compositions from this period include Piano Sonata No. 1 SonataFantasy, Op. 39 and Piano Sonata No. 2, Op. 54, one of his most well-known works. Eight Concert Etudes, Op. 40 and Twenty-Four Preludes for Piano, Op. 53 were also composed during this time.

\footnotetext{
${ }^{81}$ Steele, 37.
} 
Kapustin himself considers the beginning of the 1990's as his short modern period. ${ }^{82}$ What is the modern style? For the contemporary composer this style is signified by the diversity of different musical influences, their interaction, experimentation, reinterpretation, and, as a result, innovation of musical style. Kapustin's modern style is influenced by the Piano Sonatas of Scriabin and serial techniques of composers such as Schoenberg, Webern, and Berg. According to the composer, this period was from around 1991 to 1993 . Works from this modern period include the Piano Sonata No. 3, Op. 55, Piano Sonata No. 4, Op. 60, Piano Sonata No. 5, Op. 61, and Ten Inventions for Piano, Op. $73 .^{83}$

During this decade the composer's output almost doubled from 25 pieces in the previous decade to 45 pieces for the decade of the 1990's. In addition, some of the pieces were not just short character pieces but larger-scale compositions. For example, his famous cycle of TwentyFour Preludes and Fugues for Piano, Op. 82 and the Third through Tenth Piano Sonatas were composed. Also during this period Kapustin started to compose more chamber music. The Sonata for Viola and Piano, Op. 69, String Quartet, Op. 88, Piano Quintet, Op. 89, and Piece for Sextet, Op. 79 were composed in the 1990's. Orchestral music was represented by the Concerto for Double-Bass and Symphony Orchestra, Op. 76, Concerto for Eleven Instruments, Op. 90, and Fourth and Fifth Piano Concertos, Op. 72 and 74. In addition, Kapustin experimented with the genre of orchestral-chamber music. His Chamber Symphony for Chamber Orchestra, Op. 57 was composed in 1990 .

In the 2000's Kapustin continued to write solo piano music as well as chamber works. His output continues to be impressive, 42 compositions over the decade from 2000 to 2010 . He finished his Eleventh through Twentieth Piano Sonatas, and wrote a significant number of

\footnotetext{
${ }^{82}$ Nikolai Kapustin, interview by author, December 27, 2013.

${ }^{83}$ Nikolai Kapustin, interview by author, July 9, 2014.
} 
character pieces for piano. During the 2000's he started to write arrangements of famous jazz tunes. For example, Paraphrase on “Aqua de Brazil” by Ary Barroso for Piano, Op. 118, Paraphrase on "Blue Bossa" by Kenny Dorham for Piano, Op. 123, Paraphrase on Dizzy Gillespie's "Manteca" for Two Pianos, Four Hands, Op. 129, and the Variations on "Sweet Georgia Brown" for Viola, Alto-Saxophone, Piano and Bass, Op. 107. He continued to compose chamber music during this period. Chamber pieces include Suite for Viola, Alto-Saxophone, Piano and Bass, Op. 106, Sonata for Flute and Piano, Op. 125, String Quartet No. 2, Op. 132, and the Piano Trio No. 1 for Violin, Cello and Piano, Op. 136.

This output shows a wide variety of influences and genres. We now turn to a discussion of the twenty piano sonatas. 


\section{Chapter Five}

\section{Overview of Twenty Piano Sonatas}

In the middle 1980’s Nikolai Kapustin began writing virtuoso compositions for solo piano. His twenty piano sonatas were composed during the years 1984 to 2012 .

The year 1984 has significant meaning for Kapustin as a composer because during that year he resigned from his position as a pianist for the State Symphonic Orchestra of Cinematography. Thus, being absolutely free from any obligation, he was able to fully pursue the composition of piano music.

Kapustin began to compose piano sonatas surprisingly late in his career. The Piano Sonata No. 1, Op. 39 was composed in 1984, which is almost thirty years after his first opus number in 1957. ${ }^{84}$ This can be explained by the fact that in the 1960's and 1970's Kapustin was more interested in composing pieces for piano and jazz orchestra since his life at that time centered around his work with the Oleg Lundstrem Big Band and Boris Karamishev "Blue Screen" Orchestra.

The composer does not plan to write any more piano sonatas. He feels that twenty sonatas are enough. He does not want to overcome such famous numbers as 22 (Schubert), 32 (Beethoven), or 550 (Scarlatti). In my interview with Kapustin he stated: "My musical language is more difficult than the musical language of the composers from the Classical or Romantic periods. In other words, it takes me a longer time to write a sonata in comparison to Scarlatti, Schubert, or Beethoven."

\footnotetext{
${ }^{84}$ De Haan, "Nikolai Kapustin," accessed July 2, 2014.

${ }^{85}$ Nikolai Kapustin, interview by author, Moscow, December 27, 2013.
} 
It is interesting to note the symmetry in numbers of the sonatas composed during each decade:

\begin{tabular}{|c|c|c|}
\hline Decades & Numbers of Sonatas & Total Sonatas \\
\hline 1980's & No. 1, No. 2 & 2 \\
1990's & No. 3- No. 10 & 8 \\
2000's & No. 11- No. 18 & 8 \\
2010's & No. 19, No. 20 & 2 \\
\hline
\end{tabular}

Chart 1

As one can see, Kapustin composed ten sonatas before 2000 and the other ten sonatas after 2000. There were two sonatas in the decade of the 1980's, eight sonatas in the 1990's, another eight sonatas in the 2000's, and the last two sonatas were composed at the beginning of present decade. According to the composer, he did not plan to compose this specific number of sonatas in each decade. However, this fact implies that Kapustin intuitively has a unique sense of symmetry.

Piano Sonata No. 1, Op. 39 was composed in 1984. It has the nickname "Sonata-Fantasia," and is a four-movement work. Five years later, in 1989, he composed Piano Sonata No. 2, Op. 54. The Sonata No. 2 is one of the most well-known sonatas of all twenty. The initial popularity of this sonata comes from the recordings by Nikolai Petrov and Steven Osborne. In 2000 the popularity increased with the performance of Marc-Andre Hamelin on his tour around the world. ${ }^{86}$ This is one of the longest sonatas as it is 22 minutes in length. The sonata consists of

\footnotetext{
${ }^{86}$ Anderson, 93.
} 
four movements: "Allegro molto" (mvt 1), Scherzo "Allegro assai" (mvt 2), "Largo" (mvt 3), and Perpetuum mobile "Allegro vivace" (mvt 4).

During the 1990's Kapustin composed eight piano sonatas, beginning with Piano Sonata No. 3, Op. 55 and ending with Piano Sonata No. 10, Op. 81. During the year 1991 Kapustin composed four piano sonatas in succession: Piano Sonata No. 4, Op. 60, Piano Sonata No. 5, Op. 61, Piano Sonata No. 6, Op. 62, and Piano Sonata No. 7, Op. 64.

In our interview, Kapustin commented about the works from the early 1990's: "Sonata No. 3 indicates the beginning of my short period of the modern style. Sonatas No. 4 and No. 5 also belong to that period. ${ }^{, 87}$ During this time Kapustin stopped indicating the key signature, used extended tonalities, and even experimented with the idea of the twelve-tone row. His music became more complex tonally, harmonically, and rhythmically.

It is important to note one of the major characteristics of Kapustin's compositional process in the sonatas. The composer works with similar musical material not only in the scope of one particular sonata but also within a series of different sonatas. For example, the idea of the short motive from Sonata No. 3, Op. 55 would be later developed within Sonatas No. 4, and No. 5. The opening movement of Sonata No. 3, Op. 55 is based on the short 5-note motive (A F\# G D\# C\#). In the same way, Kapustin uses a 6-note melodic motive (F G D C F Eb) in Sonata No. 5, Op. 61. Beginning with Sonata No. 3 the composer presents the opening section as a kaleidoscope of contrasting moods, different musical ideas. The Sonatas No. 4, No. 5, and No. 6 follow this pattern also.

Sonata No. 7, Op. 64 is a four-movement work. This is one of Kapustin's longest sonatas, since it is more than 20 minutes in length. Piano Sonata No. 8, Op. 77 was composed in 1995

\footnotetext{
${ }^{87}$ Nikolai Kapustin, interview by author, Moscow, December 27, 2013.
} 
and is one of three sonatas which consist of only one movement. The other two sonatas are Sonata No. 3, Op. 55 and Sonata No. 15, Op. 127.

Piano Sonata No. 9, Op. 78 was also composed in 1995. It has three movements. This is the only sonata out of all twenty which has an Interludio section between the second and third movements. Sonata No. 10, Op. 81 was composed in 1996 and it is a three-movement work. An interesting fact is that after this sonata Kapustin composed his famous set of Twenty-Four Preludes and Fugues, Op. 82.

From 2000 to 2010 Kapustin composed another eight sonatas. These include Piano Sonata No. 11, Op. 101 through Piano Sonata No. 18, Op. 135. The Piano Sonata No. 11, Op. 101 was composed in 2000 and it is a three movement work. The sonata has the nickname “Twickenham.” It was written after Kapustin's trip to England in the spring of 2000 and was dedicated to Twickenham, a borough of the southwest area of London.

Piano Sonata No. 12, Op. 102 was composed in 2001, and it is one of his shortest sonatas, only 12 minutes in length. This is one of Kapustin's works that most pleases the composer. Usually, Kapustin is very critical of his works from the past. ${ }^{88}$ Another important characteristic of this sonata is that it is the only two-movement sonata out of all twenty sonatas. The first movement "Allegretto" sounds like a jazz fantasy, totally improvised music. The second movement "Allegro assai" is a jazz-rock virtuoso finale with almost no breaks in its intensity. It is a technically demanding piece, almost exceeding the limits of the keyboard. The texture of the sonata is very dense with multiple lines presented simultaneously. The only recording of this sonata that exists at the present time is played by Nikolai Kapustin. It gives the listener a perfect understanding of the composer's concept of his music. It would be extremely difficult to learn this sonata just from the score without listening to the recording.

\footnotetext{
${ }^{88}$ Nikolai Kapustin, interview by author, Moscow, December 27, 2013.
} 
The Piano Sonata No. 13, Op. 110 was composed in 2003 and it is a four-movement work. The Piano Sonata No. 14, Op. 120 was written in 2004 and it is a three-movement work. Piano Sonata No. 15, Op. 127 "Fantasia quasi Sonata" was composed in 2005. It is one of the three sonatas which consist of only one movement. However, it is possible to subdivide this sonata into four parts. Kapustin insisted on calling it a one-movement work. He feels the sonata should be seen as a whole, one continuous motion, and should not be separated by rests at the end of each part. The rest has a significant meaning for the composer. ${ }^{89}$

The following three sonatas, Sonata No. 16, Op. 131, Sonata No. 17, Op. 134, and Sonata No. 18 , Op. 135, are all three-movement works. Sonata No. 17 was dedicated to the Italian pianist Vito Reibaldi. ${ }^{90}$

Since 2010 only two sonatas have been composed. These are Piano Sonata No. 19, Op. 143 and the Sonata No. 20, Op. 144. Both sonatas were composed in 2011. Sonata No. 19 consists of four movements and it is dedicated to the Russian pianist Alexei Volodin. Sonata No. 20 is a three-movement work. ${ }^{91}$ Unfortunately, the last four piano sonatas have not yet been recorded or published.

To summarize:

First, the majority of the sonatas are 14-17 minutes in length with the exception of three sonatas (Sonata No. 2, Op. 54, Sonata No. 7, Op. 64, and Sonata No. 15, Op. 127) which last more than 20 minutes.

Second, the number of movements varies from one to four with the predominance of three to four movement works. There are only three one-movement sonatas: Piano Sonata No. 3, Op. 55, Piano Sonata No. 8, Op. 77, and Piano Sonata No. 15, Op. 127. In two of these one-

\footnotetext{
${ }^{89}$ Nikolai Kapustin, interview by author, Ruza, July 9, 2014.

${ }^{90}$ Ibid.

${ }^{91}$ Ibid.
} 
movement sonatas it is possible to identify the features of three to four parts. For example, the one-movement Piano Sonata No. 3, Op. 55 consists of three parts inside. At the same time, Piano Sonata No. 15, Op. 127 holds four parts inside a large one-movement form. However, Piano Sonata No. 8, Op. 77 has different characteristics. It seems to be a large sonata-allegro form since the opening material, a section strongly reminiscent of Scriabin, comes back near the end of the sonata. The clear Recapitulation helps establish a strong sense of sonata-allegro form in this one-movement work.

Third, most of Kapustin's sonatas are based on a dramatic contrast between the movements. In the three-movement works, for example in the Sonatas No. 4, No. 5, and No. 6, the first movement may represent the sketch of different musical ideas. It could be sectional or written in the sonata-allegro form, as in the Sonata No. 2. The middle movements are always slow, chorale-like, dreamy in mood, such as in the Sonatas No. 6, No. 11, No. 13, No. 14, and No. 15. Kapustin's finales are always virtuoso and perpetual-motion in character, full of energy and drive. In the four-movement sonatas, the second and fourth movements are fast and the third movement is in a slow, meditative character. ${ }^{92}$

Fourth, according to the composer, there are only two quotes from earlier music to be found in the set of twenty piano sonatas. One is a quote of the "Dies Irae" theme in the Piano Sonata No. 3, Op. 55 and the second is a quote of Beethoven's Piano Sonata "Pathetique," Op. 13 in the Piano Sonata No. 9, Op. $78 .^{93}$

Fifth, there are only three sonatas which have nicknames. These are: Piano Sonata No. 1 “Sonata-Fantasia," Op. 39, Piano Sonata No. 11 "Twickenham,” Op. 101, and Piano Sonata No. 15 “Fantasia quasi Sonata,” Op. 127.

\footnotetext{
92 Roberts, 33.

${ }^{93}$ Nikolai Kapustin, interview by author, Moscow, December 27, 2013.
} 
Sixth, there are only two sonatas which are dedicated to famous pianists. The Piano Sonata No. 17, Op. 134 is dedicated to the Italian pianist Vito Reibaldi, and Piano Sonata No. 19, Op. 143 is dedicated to the Russian pianist Alexei Volodin. ${ }^{94}$

In conclusion, starting from the late 1980's, Nikolai Kapustin himself recorded nine of the piano sonatas. These are Sonatas No. 1 through No. 7 , No. 12 , and No. $16{ }^{95}$ These recordings make an essential impact on performers who are in the process of learning and understanding his music. Hopefully, within a few years, we will have an opportunity to hear more music composed and performed by Nikolai Kapustin.

Now we turn to a detailed discussion of the Piano Sonata No. 3, Op. 55.

${ }^{94}$ Nikolai Kapustin, interview by author, Ruza, July 9, 2014.

${ }^{95}$ Nikolai Kapustin, e-mail to author, October 28, 2014. 


\begin{tabular}{|c|c|c|c|c|c|c|}
\hline Sonata & Opus & Year & Movements & Length & Nickname & Dedication \\
\hline Sonata No. 1 & Op. 39 & 1984 & 4 & $18: 17$ & $\begin{array}{l}\text { Sonata - } \\
\text { Fantasia }\end{array}$ & \\
\hline Sonata No. 2 & Op. 54 & 1989 & 4 & $22: 23$ & & \\
\hline Sonata No. 3 & Op. 55 & 1990 & 1 & $15: 19$ & & \\
\hline Sonata No. 4 & Op. 60 & 1991 & 3 & $12: 27$ & & \\
\hline Sonata No. 5 & Op. 61 & 1991 & 3 & $11: 57$ & & \\
\hline Sonata No. 6 & Op. 62 & 1991 & 3 & $13: 15$ & & \\
\hline Sonata No. 7 & Op. 64 & 1991 & 4 & $20: 46$ & & \\
\hline Sonata No. 8 & Op. 77 & 1995 & 1 & $13: 26$ & & \\
\hline Sonata No. 9 & Op. 78 & 1995 & 3 & $16: 34$ & & \\
\hline Sonata No. 10 & Op. 81 & 1996 & 3 & $12: 33$ & & \\
\hline Sonata No. 11 & Op. 101 & 2000 & 3 & $17: 26$ & Twickenham & \\
\hline Sonata No. 12 & Op. 102 & 2001 & 2 & $12: 22$ & & \\
\hline Sonata No. 13 & Op. 110 & 2003 & 4 & $16: 22$ & & \\
\hline Sonata No. 14 & Op. 120 & 2004 & 3 & $14: 50$ & & \\
\hline Sonata No. 15 & Op. 127 & 2005 & 1 & $23: 15$ & $\begin{array}{l}\text { Fantasia quasi } \\
\text { Sonata }\end{array}$ & \\
\hline Sonata No. 16 & Op. 131 & 2006 & 3 & $14: 23$ & & \\
\hline Sonata No. 17 & Op. 134 & 2008 & 3 & $16: 00$ & & $\begin{array}{l}\text { Vito } \\
\text { Reibaldi }\end{array}$ \\
\hline Sonata No. 18 & Op. 135 & 2008 & 3 & $15: 08$ & & \\
\hline Sonata No. 19 & Op. 143 & 2011 & 4 & $17: 44$ & & $\begin{array}{l}\text { Alexei } \\
\text { Volodin }\end{array}$ \\
\hline Sonata No. 20 & Op. 144 & 2011 & 3 & $14: 48$ & & \\
\hline
\end{tabular}

Chart 2: Timing for the sonatas are taken from the flowing recordings: Sonatas No. 1-7, 12, 16 - Nikolai Kapustin, Sonata No. 9 - Vadim Rudenko, Sonatas No. 8, 10 - Carlo Levi Minzi, Sonatas No. 11, 13 - Masahiro Kawakami, Sonata No. 14 - Ludmil Angelov, Sonata No. 15 John Salmon. Since there are no recordings yet available, timing for the Sonatas No. $17-20$ are estimated after consulting the scores. 


\section{Chapter Six}

\section{Analysis of Piano Sonata No. 3, Op. 55}

The Piano Sonata No. 3, Op. 55 was composed in 1990. It was published in August 2014 by Schott Music, twenty four years after it was composed. Sonata No. 3 is unknown to a large audience. Even though it was composed within the same period as some of Kapustin's most famous works, such as Piano Sonata No. 2, Op. 54 (1989) and Concerto for Piano and Orchestra No. 4 Op. 56, (1990), it still remains relatively unknown.

According to the composer, Piano Sonata No. 3 represents the beginning of his short modern period. Starting with this work Kapustin stopped indicating the key signature, started to use more complex harmonic and rhythmic language, and even experimented with serial technique. At the same time, this sonata is unusual for Kapustin because it contains a quote of the "Dies Irae" (mm. 60-61). Again, according to the composer, out of all twenty sonatas only two quotes were utilized. The second quote is from the first movement of Beethoven's "Pathetique" Sonata, Op. 13, and occurs in the first movement of Piano Sonata No. 9, Op. $78 .{ }^{96}$

Sonata No. 3 is a large one-movement work and it is fifteen minutes (or more) in length. ${ }^{97}$ It is possible to subdivide this work into three separate parts. The double bar lines and the indication of the new character, tempo, and the key area suggests the beginning of each new section. Therefore, this sonata is written in three-part form where each part may be interpreted as a complete movement. However, the composer strongly feels this sonata should be seen as a onemovement work since the musical material is presented without any stop between the parts. ${ }^{98}$ In addition, all the musical ideas in this sonata are closely related.

\footnotetext{
${ }^{96}$ Nikolai Kapustin, interview by author, Moscow, December 27, 2013.

97 Timing of the Sonata No. 3 based on the recording by Nikolai Kapustin.

${ }^{98}$ Nikolai Kapustin, interview by author, Moscow, December 27, 2013.
} 
The three parts of Sonata No. 3 present a unique scheme.

\begin{tabular}{|c|c|c|c|c|}
\hline Part & Measures & $\begin{array}{c}\text { Number of } \\
\text { measures }\end{array}$ & Timing & Length \\
\hline Part I & $1-158$ & 158 & $0: 00-7: 11$ & $7: 11$ \\
Part II & $159-196$ & 38 & $7: 12-10: 26$ & $3: 14$ \\
Part III & $197-387$ & 191 & $10: 27-15: 12$ & $4: 45$ \\
\hline
\end{tabular}

Chart 3

Part I represents the main body of the sonata, since it is almost half of the work by length. Part II is much shorter than Part I and Part III. Obviously, Part III is the most extensive section by number of measures, but because of the fast tempo it is only 4 minutes and 45 seconds in length.

All three parts are very different in character. Part I is a kaleidoscope of different moods: improvisatory Theme A1, technical and very chromatic Theme A2, swing style Theme A3, lyrical and retrospective Theme B, and later on, the motoric nature of Theme C. Part II is an equivalent of the slow movement in the traditional sonata-allegro form. It has a retrospective quality within and is characterized by the use of contrapuntal texture. Part III sounds like one of Kapustin's virtuoso finales. It is dedicated to the swing style, although it has a section in jazzrock style as well as a section where Kapustin experiments with serial techniques. The last of four major themes of the sonata, Theme D, is introduced in Part III providing contrast to the predominant Theme C. 
Part I (mm. 1-158)

Part I is written in modified sonata-allegro form. It has Exposition, Development, Recapitulation, and Coda sections.

\begin{tabular}{|l|c|c|c|c|}
\hline \multicolumn{1}{|c|}{ Part I: Sections } & Measures & $\begin{array}{c}\text { Number of } \\
\text { measures }\end{array}$ & Timing & Length \\
\hline Exposition & $1-70$ & 70 & $0: 00-4: 28$ & $4: 28$ \\
Theme A1 & $1-20$ & 20 & \\
Theme A2 & $21-30$ & 10 & \\
Theme A3 & $31-42$ & 12 & \\
Theme B & $43-70$ & 28 & $3: 50-3: 55$ & 05 \\
Quote "Dies Irae" & $60-61$ & 2 & $4: 29-5: 48$ & \\
Development & $71-117$ & 47 & & \\
Theme A1, Theme A2 & & & & \\
material & $118-150$ & 33 & $5: 49-6: 44$ & \\
"Mirror" Recapitulation & $118-131$ & 14 & & \\
Theme B & $132-134$ & 3 & $6: 55$ \\
Theme A1 & $135-150$ & 16 & $6: 45-7: 11$ & $0: 26$ \\
Theme A2 & $139-144$ & 6 & & \\
Theme C & & 8 & & \\
Coda & $151-158$ & & & \\
Theme A1 material & & & & \\
& & & & \\
\hline
\end{tabular}

Chart 4

Part $\mathrm{I}$ is the most extensive section of the sonata; it lasts 7 minutes and 11 seconds. Thematically, it presents three major themes (A, B, and C) out of the four existing in the sonata. Theme $\mathrm{A}$ is a group of themes as it consists of Theme A1, A2, and A3. In addition, Part I contains a quote of "Dies Irae" theme inserted in the Theme B (mm. 60-61). All these factors give additional weight to Part I in the sonata as a whole. Formally, Part I is written in the sonata- 
allegro form with a "mirror" Recapitulation, where the material of Theme A and Theme B is presented in reverse order.

Part I: Exposition (mm. 1-70)

The Exposition is a large section and it is nearly equal in length to the Development and Recapitulation sections combined. It opens with the Theme A (the group of themes) which consists of three basic mood characteristics: Theme A1 - improvisatory, Theme A2 - technical, and Theme A3 - swing style. These three themes may be seen as the presentation of the major content of the sonata during the first four pages of the work. Some may argue that Theme A2 or Theme A3 may be seen as the Theme B. However, as Kapustin pointed out in our interview, he feels that Theme B begins in $\mathrm{m} .43 .^{99}$

The extensive Lento narrante of Theme A1 (mm. 1-20) may be seen as the introduction to the sonata. It is improvisatory in character and tonally unstable. Generally speaking, the tonality is not clearly established in the sonata in a traditional sense. We may talk about the tonal centers that present some tonal connections by using the motives, ii-V-I progression, and the independently standing Dominant $7^{\text {th }}$ chords.

Following this concept, the sonata begins with the Db major tonal area (m. 1), and then moves to the B major tonal area (m. 7). It is fascinating that this harmonic change is going from the key of five flats ( $\mathrm{Db}$ major) to the distant key of five sharps (B major) within the first seven measures. Then it moves through different tonal areas and finally reaching the key area of $\mathrm{F}$ major (m. 18), which can be seen as a $3^{\text {rd }}$ relationship key to the tonal area of Db major. Theme A1 ends on the enharmonically spelled C7 chord (m. 20), which serves as a tritone substitution of the Dominant $7^{\text {th }}$ chord for the beginning of Theme A2 in a B7 tonal area.

\footnotetext{
${ }^{99}$ Nikolai Kapustin, interview by author, Moscow, December 27, 2013.
} 
The Theme A1 motive (m. 1) is a short five-note figure which is based on the intervals of maj $2^{\text {nd }}$ and maj $3^{\text {rd }}$.

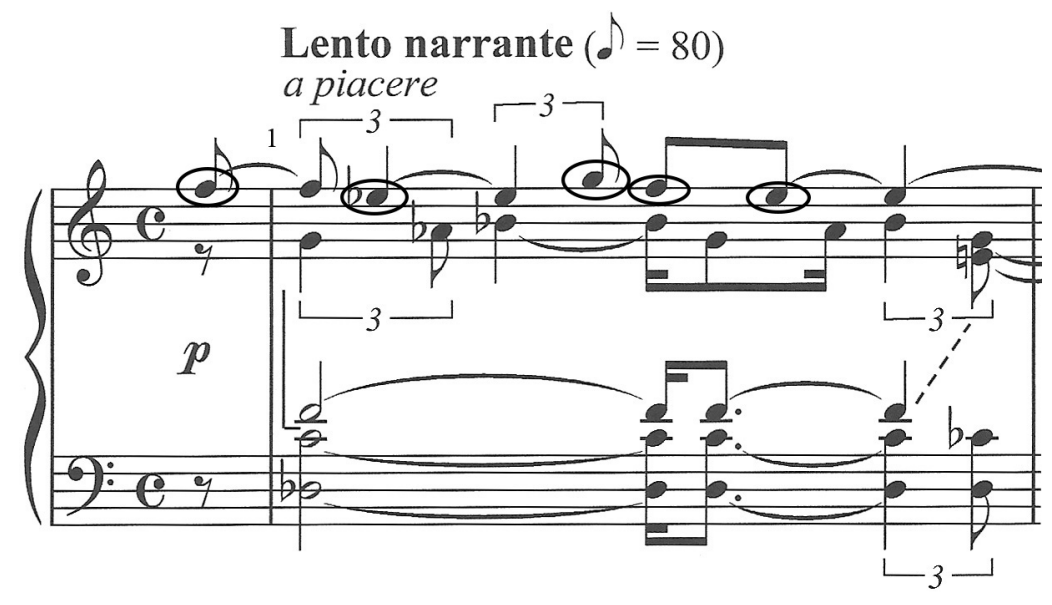

Example 1: Part I Exposition, Theme A1, m. $1^{100}$

This idea of the short motive and intervallic interrelationship within this motive will serve later as a major source for future themes in the sonata. In addition, all of these themes seem motivically connected to the "Dies Irae" Theme. This may bring us to a conclusion that the majority of the themes from the sonata are motivically derived from the quote of "Dies Irae."

This can be seen as an influence from Scriabin's piano sonatas. Jim Samson stated in his book Music in Transition: A Study of Tonal Expansion and Atonality, 1900-1920 about Scriabin's Piano Sonata No. 4: "Skryabin does show concern to interrelate the basic themes of the work by means of motivic derivations and transformations, establishing close thematic links between the movements."101

For both composers, Scriabin and Kapustin, this process resulted in the development of a highly personal harmonic language. Although in contrast to Scriabin, whose language according

\footnotetext{
${ }^{100}$ Score Examples from Piano Sonata No. 3 Op. 55 Schott Edition are used with permission from Nikolai Kapustin. ${ }^{101} \mathrm{Jim}$ Samson, Music in Transition: A Study of Tonal Expansion and Atonality, 1900-1920 (New York: W.W. Norton, 1977), 82.
} 
to Samson, had a "serious lack of harmonic variety and contrast resulting from Skryabin's tendency to dispose his sets in dominant-quality areas," complex. Sometimes it is even hard to follow all the changes of tonal areas as they are changing so quickly.

It is an interesting fact that both composers graduated from the Moscow Conservatory as classical pianists, neither had official training in composition (Scriabin studied but didn't graduate as a composer), and at a certain point in their career both rejected official work.

Stylistically, Theme A1 also has the features of the Impressionistic style. Kapustin's interest in sustained sound (mm. 2, 3, 7, and 8), harmonic motion of parallel chords (m. 5), coloristic use of pedal, and the use of $7^{\text {th }}, 9^{\text {th }}$, and $13^{\text {th }}$ chords shows the influence of the music of Ravel and Debussy.

In addition, this section has a hint of the future predominance of the swing style in the sonata, specifically in Part III (m. 12).

Theme A2 (mm. 21-30) is a contrasting energetic and highly technical theme.

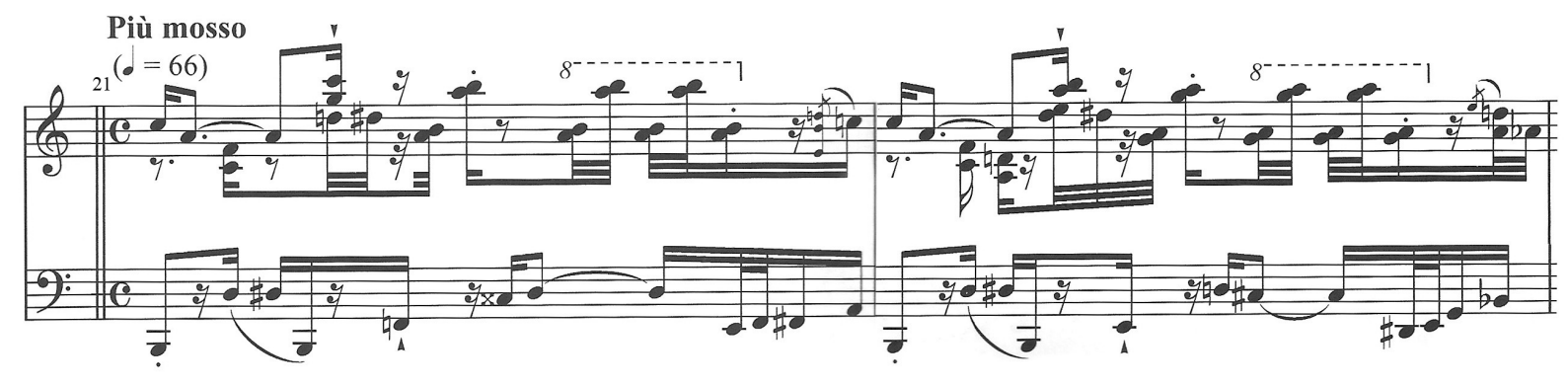

Example 2: Part I Exposition, Theme A2, mm. 21-22

The predominant note value in this section is the $16^{\text {th }}$ and $32^{\text {nd }}$. Harmonically, this is very chromatic material. It begins on the tonal area based on the B7 chord, which may be analyzed as

${ }^{102}$ Samson, 210. 
a flat VII chord in the key area of $\mathrm{Db}$, the enharmonic spelling of the $\mathrm{Cb} 7$ chord. This $\mathrm{B} 7$ tonal center comes back closer to the end of this section (m. 28). Thematically, the passages of Theme A2 are based on the succession of different intervals in the right hand $\left(2^{\text {nd }}, 3^{\text {rd }}, 4^{\text {th }}\right.$, and $\left.5^{\text {th }}\right)$ with persistently repeated interval of the $5^{\text {th }}$ in the left hand.

Theme A3 (mm. 31-42) represents a swing style. The tonal area of the Eb7 (mm. 31-38) sounds quite stable. It will be contrasted later with the tonal area of C7 (mm. 39-40).

There is a hint of Theme $\mathrm{C}$ in the alto voice (mm. 31.4-32.2 $2^{103}$ and mm. 39.4-40.2) which was inserted in the Theme A3 material.

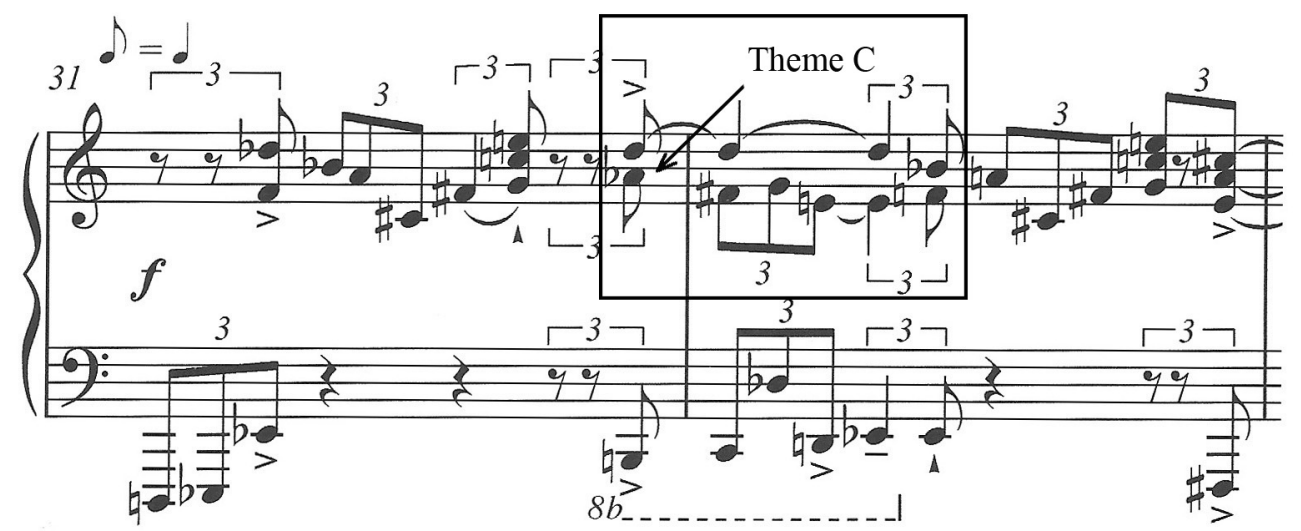

Example 3: Part I Exposition, Theme A3, mm. 31-32

The thematic idea of Eb blues also initially appears in this section (mm. 34-38). The walking bass figures, together with the Count Basie short, accented chords in the high register, exemplify the main features of this section. The Eb blues idea will be fully presented in Part III (Theme D, mm. 228.3-236).

\footnotetext{
${ }^{103}$ This measure numbering indicates the number of the measure and the number of the beat.
} 

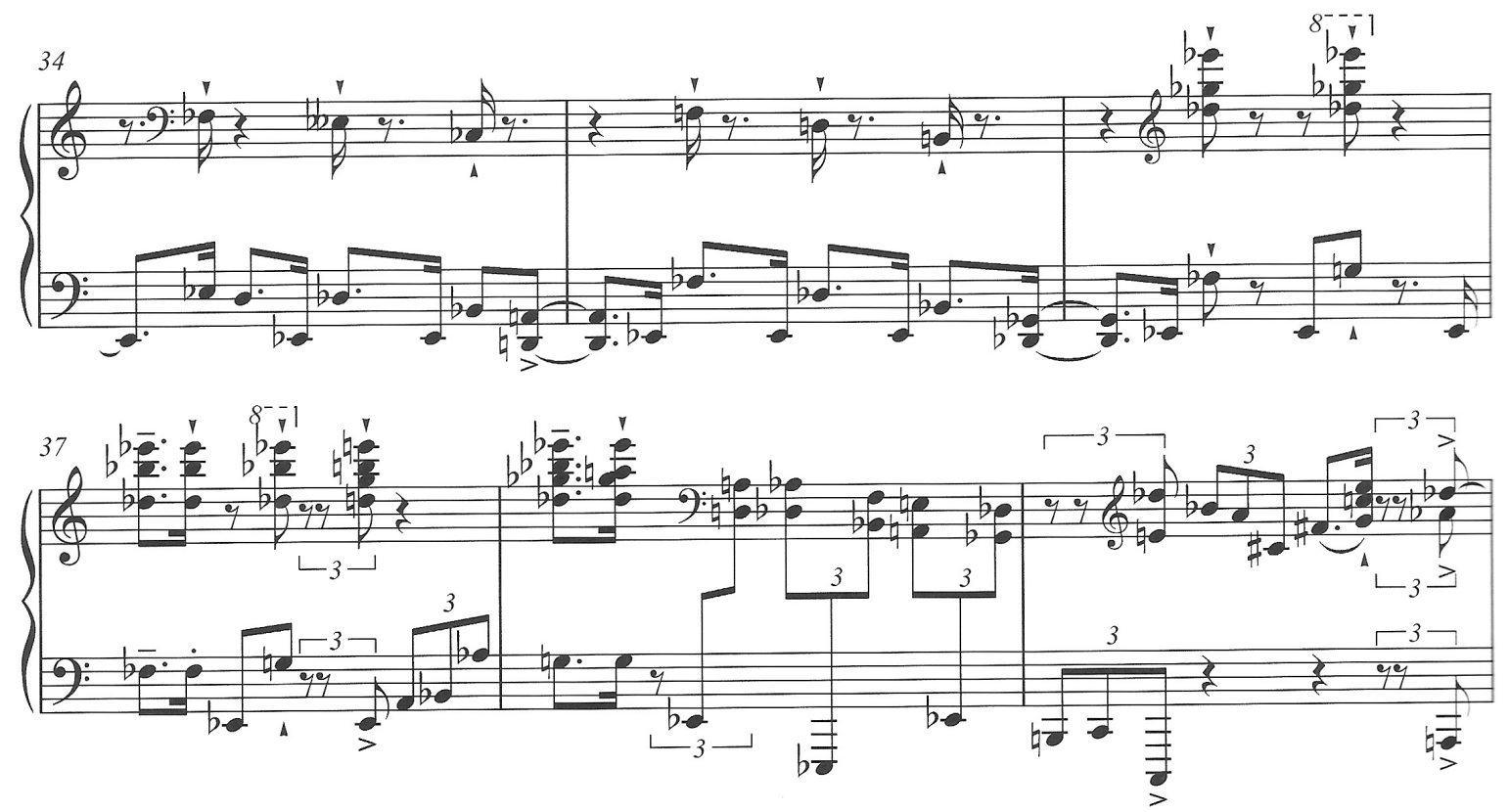

Example 4: Part I Exposition, Theme A3, Eb blues idea, mm. 34-37

In general the swing style, briefly mentioned in Part I, will be the major source for Part

III.

Theme B (mm. 34-70) is lyrical in character and free in motion.

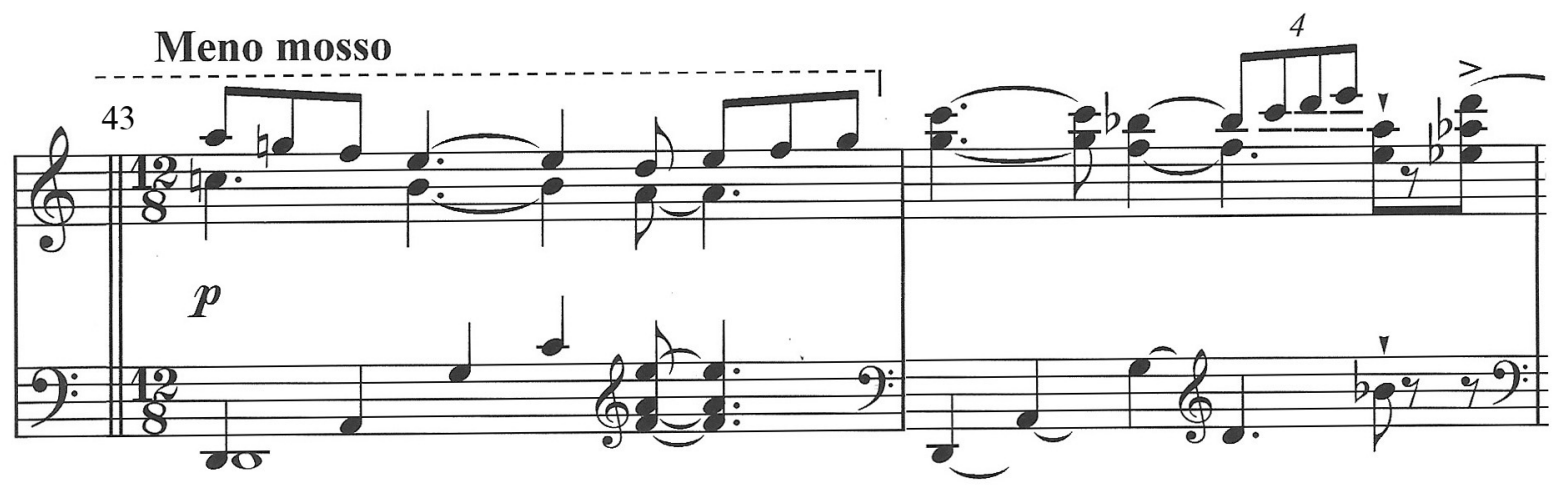

Example 5: Part I Exposition, Theme B, mm. 43-44 
Following the concept of traditional sonata-allegro form, Theme B represents a contrast to the Theme A group of themes. The melody of this theme recalls the theme of the famous jazz standard "Stella by Starlight" by Victor Young. An interesting fact is that the harmonic framework of the song itself is unstable as well as the tonal plan of Theme B which is constantly moving from one key area to another. It begins in the key area of D minor (mm. 43-48), and then moves away through a succession of different key areas. In addition, Theme B (which will be referred to as the "Stella Theme") may be seen as a thematic source for Theme D which appears later in the Part III.

The following material can be considered as one of the major moments of the sonata. Kapustin inserted a quote of the "Dies Irae" theme within Theme B material. The quote is presented in the tonal area of $\mathrm{F} \#$ minor (mm. 60-61).

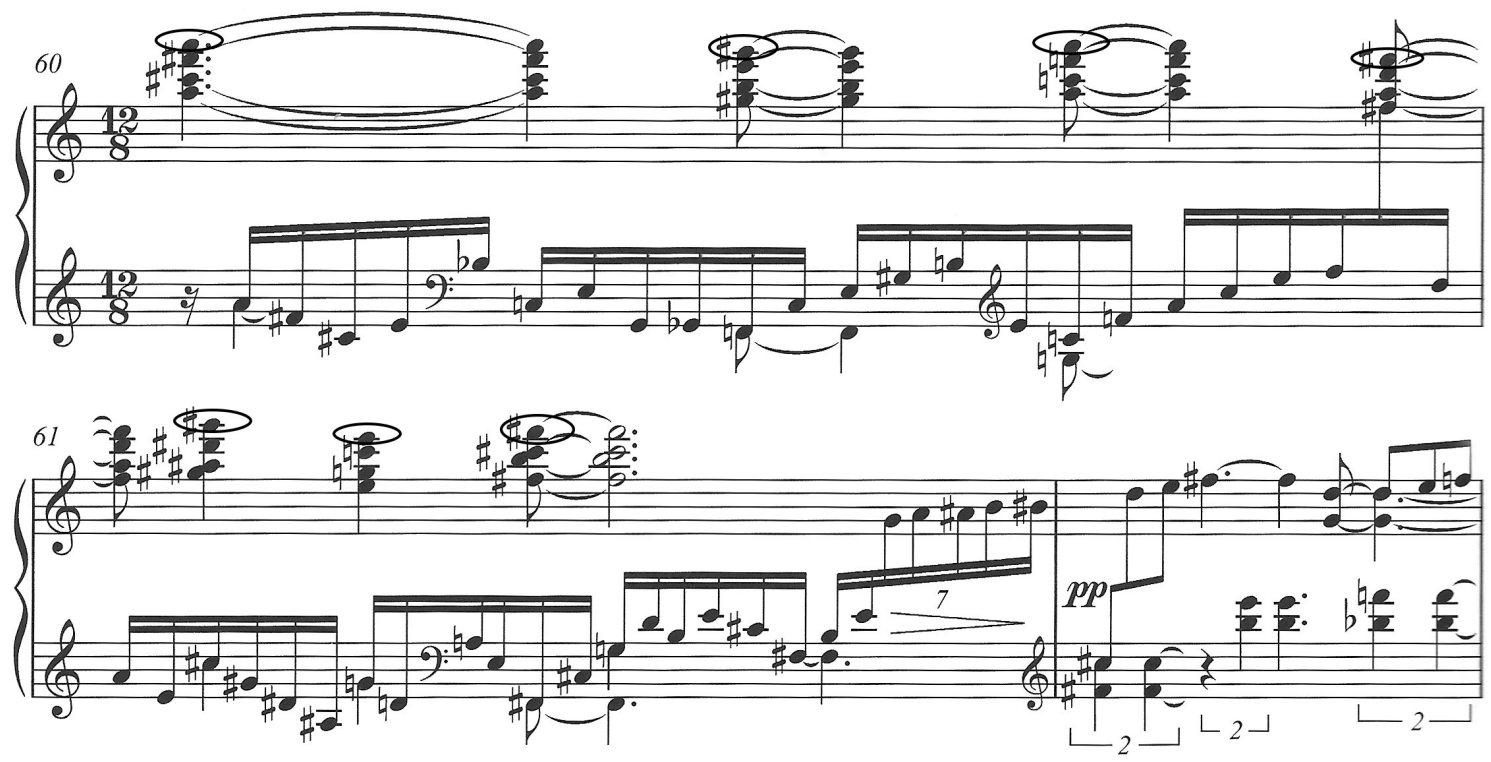

Example 6: Part I Exposition, "Dies Irae" theme, mm. 60-61 
Due to the harmonic and rhythmic complexity of this section it is difficult to identify this theme within this material, even with the fact that it is presented in the top voice. Intervallically, this quote is built upon the succession of intervals of the $2^{\text {nd }} \mathrm{s}$ and $3^{\text {rd }} \mathrm{s}$. This may bring us to the conclusion that the majority of the themes of the sonata are tied to the quote of "Dies Irae" and intervallically originated from this theme.

Part I: Development (mm. 71-116)

The Development section is quite short proportionally, only 1 minute and 19 seconds in length. It begins on the $\mathrm{C} 7$ chord (m. 71-73), and later, using sequential motion, modulates to the Bb7 chord (m. 97-99). This section is also harmonically unstable. The major source of the thematic development is linked to the Theme A1 (see Example 1) in addition to the motoric nature of Theme A2 (see Example 2).

An interesting compositional device is used by Kapustin in mm. 108-117. This is the example of the inverted texture, where the textural material is derived from mm. 89-96.

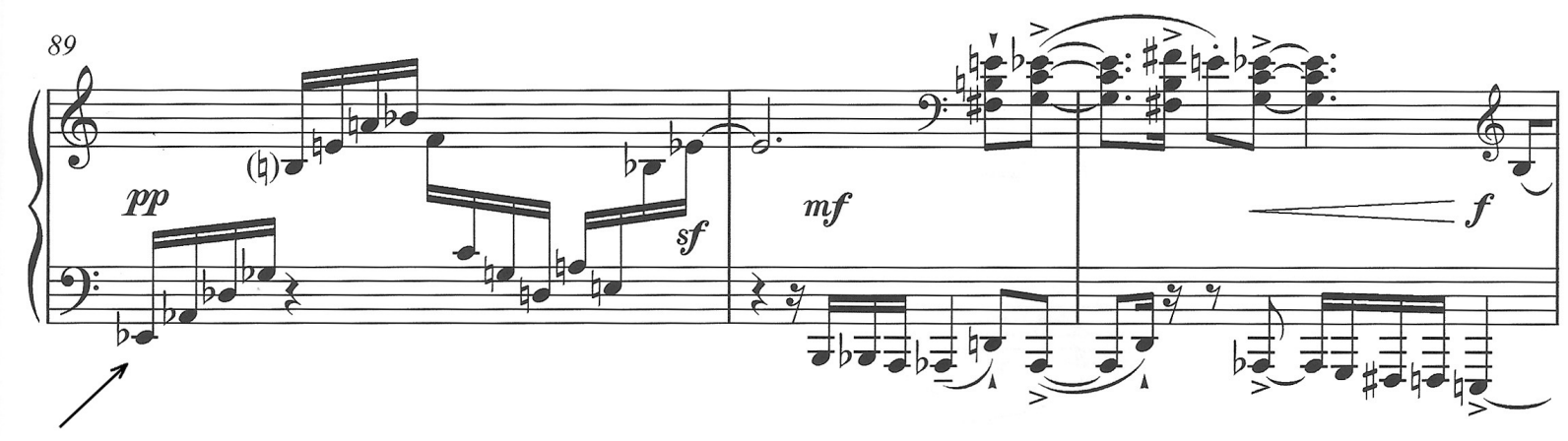

Example 7.1: Part I Development, mm. 89-91

The material in $\mathrm{mm} .108-110$ represents exactly the same texture as $\mathrm{mm}$. 89-91. The only difference is that this is "mirrored" texture. In m. 89 it begins in the low register and 
ascends where the material of $\mathrm{m} .108$ begins in the high register and descends. Thematically this is exactly the same material which gets inverted and transposed.

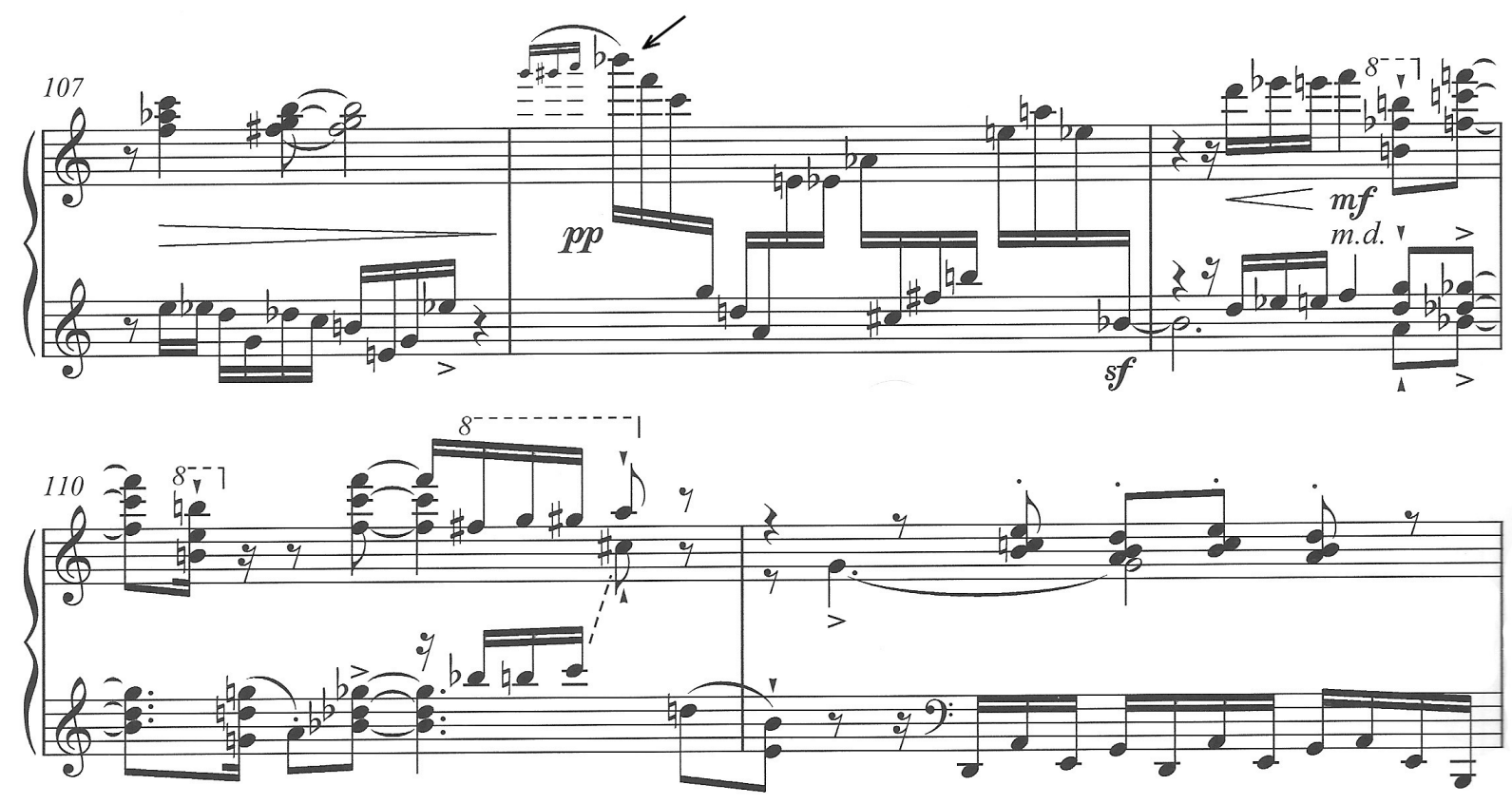

Example 7.2: Part I Development, inverted texture, mm. 108-110

Part I: Recapitulation (mm. 118-150)

The Recapitulation section is also quite short since it is only 33 measures in length. It begins with Theme B (mm. 118-131, see Example 5). This is traditionally called the "mirror" Recapitulation since Theme A and B appear in the reverse order. Theme B is harmonically complex and may be seen as bitonal: the right hand is written in the enharmonically spelled $\mathrm{E}$ major while the left hand is going through different key areas, such as $\mathrm{Bb}, \mathrm{Eb}, \mathrm{A}$, and back to $\mathrm{Bb}$. At the end of Theme B one may hear that Kapustin recalls in the left hand one of the most wellknown blues tunes "My Mama Done Told Me" by Harold Arlen (mm. 127-129). It is important 
to note that some of Kapustin's melodic fragments sound very similar to jazz tunes. According to the composer, these similarities are unintentional. ${ }^{104}$

The material of Theme A1 (mm. 132-134) comes back after Theme B, recalling the texture and the same sequence of chords from the opening of the sonata: D min7, C maj7, A half diminished chord (mm. 132-133 similar to the mm. 10-11). Theme A1 begins in the key area of D minor (m. 132) and moves to the key area of G major (m. 134). The following material represents the technical component of Theme A2 (mm. 135-138). This section is also harmonically unstable.

A new theme, Theme C (mm. 139-144), is introduced closer to the end of the Recapitulation section.
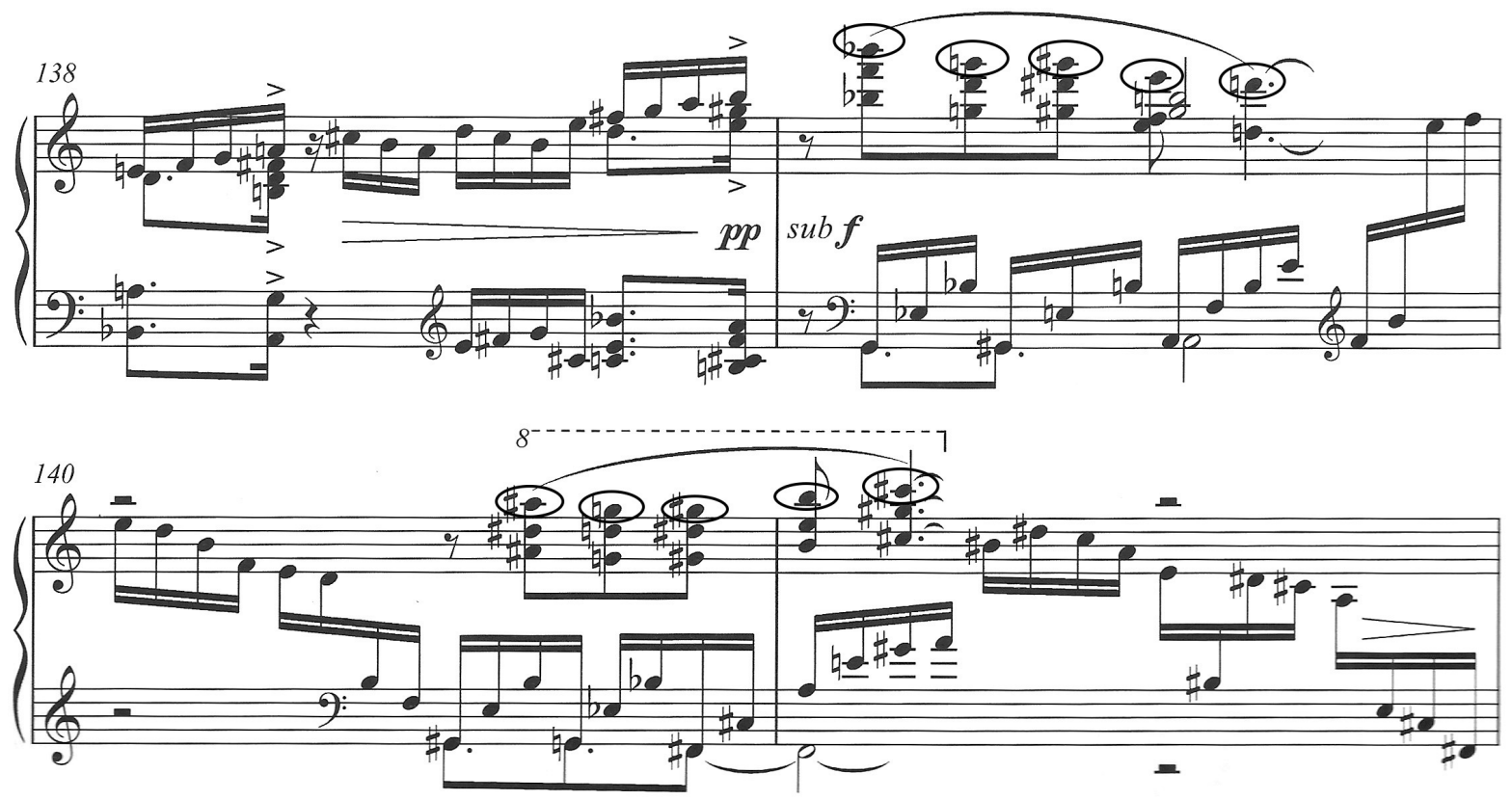

Example 8: Part I Recapitulation, Theme C, mm. 139-141

${ }^{104}$ Nikolai Kapustin, skype conversation with the author, March 22, 2015. 
This theme is motivically based upon Theme A1 (see Example 1) for its extensive use of the intervals of $2^{\text {nd }}$ and $3^{\text {rd }}$. Also, it has the characteristics of Theme A2 (see m. 24) because of its active character and chromatic language. Theme $\mathrm{C}$ was inserted in the Recapitulation in the same way "Dies Irae" was inserted in Theme B in the Exposition in Part I. It sounds very unstable. However, it will be presented as one of the most tonally stable areas in Part III and also will serve as the main thematic material for Part II and Part III.

Part I: Coda (mm. 151-158)

The Coda may also be seen as a transition to Part II. Harmonically, this section begins with the idea of falling thirds which was a common device for composers in the Romantic era. This is the succession of chords built on B major, Ab major, F major and Db minor (mm. 151152). Interesting detail, the roots of these four chords form the outline of enharmonically spelled Dominant $7^{\text {th }}$ chord (Db-F-Ab-B).

The material of mm.155-158 recalls Theme A1 (see m. 3). This gives a symmetrical aspect to Part I. The Coda of Part I ends on an F7 chord. This may be interpreted as a flat II harmony for Part II which begins in the tonal area of E minor.

Part II (mm. 159-196)

Part II represents a dramatic contrast in mood, tempo, and style to Part I and Part III. It is short since it is only 4 minutes and 14 seconds in length. Part II begins in a slow Largo tempo, where the quarter note equals 50 beats per minute (bpm), and it is presented mainly in a contrapuntal texture. Within this part, Kapustin extensively uses contrapuntal techniques such as inversion and stretto. 
Formally, Part II contains all of the major themes from Part I which may direct us to a conclusion that Part II has the characteristics of a Development in the scope of the three Parts of the sonata.

\begin{tabular}{|l|c|c|c|c|}
\hline \multicolumn{1}{|c|}{ Part II: Themes } & Measures & $\begin{array}{c}\text { Number of } \\
\text { measures }\end{array}$ & Timing & Length \\
\hline Introduction & $159-160$ & 2 & $7: 12-7: 24$ & $0: 12$ \\
Theme C & $161-172$ & 12 & $7: 25-8: 38$ & $1: 13$ \\
Theme A1 & $162.4-164.3$ & 1.3 & $7: 34-7: 43$ & $0: 09$ \\
& $170.4-172.2$ & 1.2 & $8: 23-8: 36$ & $0: 13$ \\
Theme A2 & $173-178$ & 6 & $9: 39-9: 00$ & $0: 21$ \\
Theme B & $179-191$ & 13 & $10: 05-10: 26$ & $1: 03$ \\
Theme C & $192-196$ & 5 & & $0: 21$ \\
\hline
\end{tabular}

Chart 5

In spite of the fact that all the major themes are presented in Part II, the importance of the material is shifted from Theme A1 and Theme A2 in Part I to the material of Theme B and Theme C in Part II.

Part II begins with its own two-measure Introduction (mm. 159-160), which sets up the general mood of this section. In a slow Largo tempo, this Part represents the contrasting chorallike middle section to the sonata as a whole. It begins in the key area of E minor (m. 159), chromatically moving to the key area of D minor for the beginning of Theme $\mathrm{C}(\mathrm{m} .161)$.

Theme C (mm. 161-172) is written in four-part contrapuntal texture. Kapustin frequently uses inversion as a contrapuntal device (mm. 161-168). It is important to notice the appearance 
of the Theme A1 in the top voice (mm. 162.4-164.2 and mm. 170.4-172.2) within Theme C. Theme A1 may be seen as a counter-melody to the dominating Theme $\mathrm{C}$ in this section.
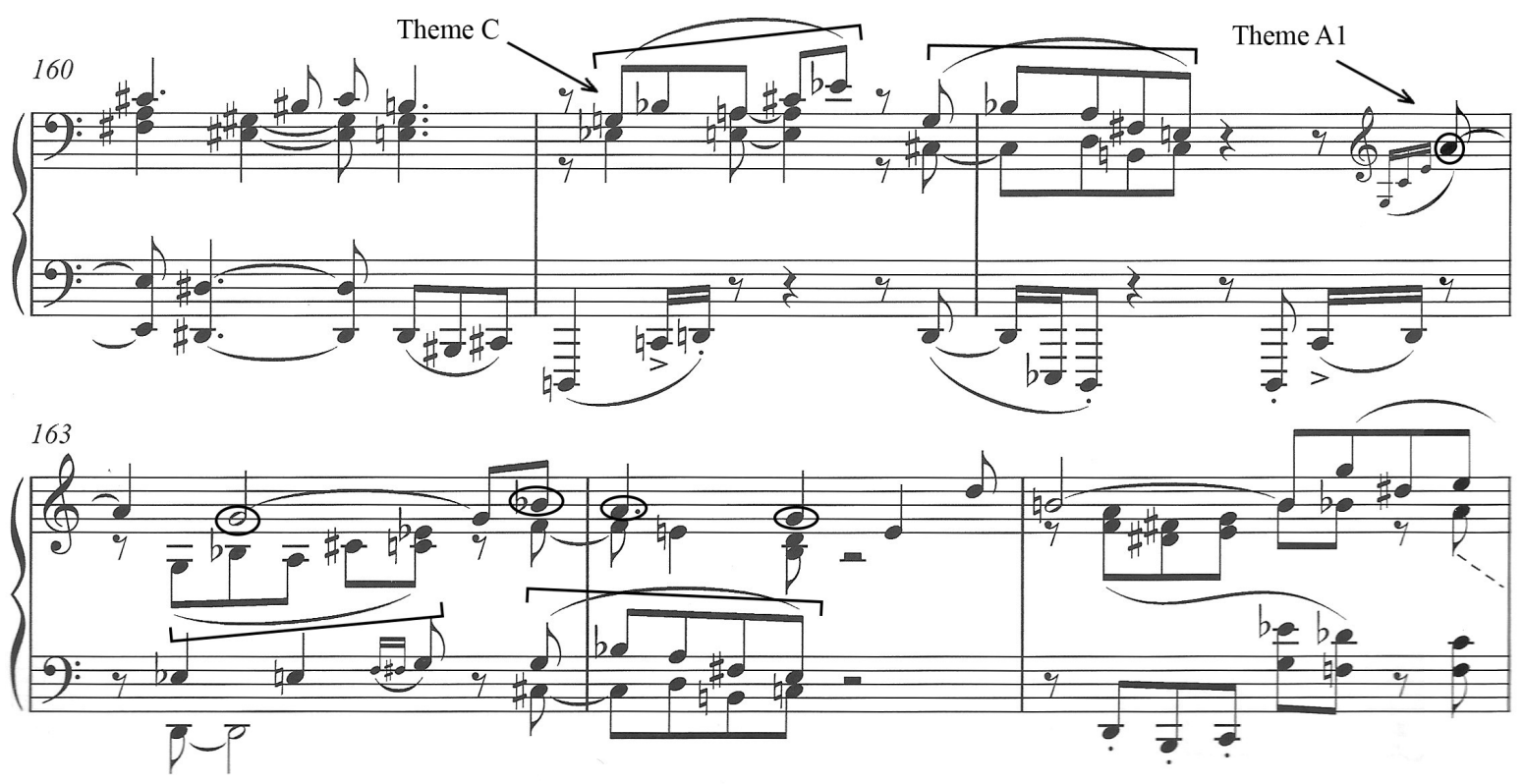

Example 9.1: Part II, Theme C, inversion, mm. 161-164

Within a few measures Kapustin begins to explore dense texture using inversion and stretto at the same time (mm. 165-168). 

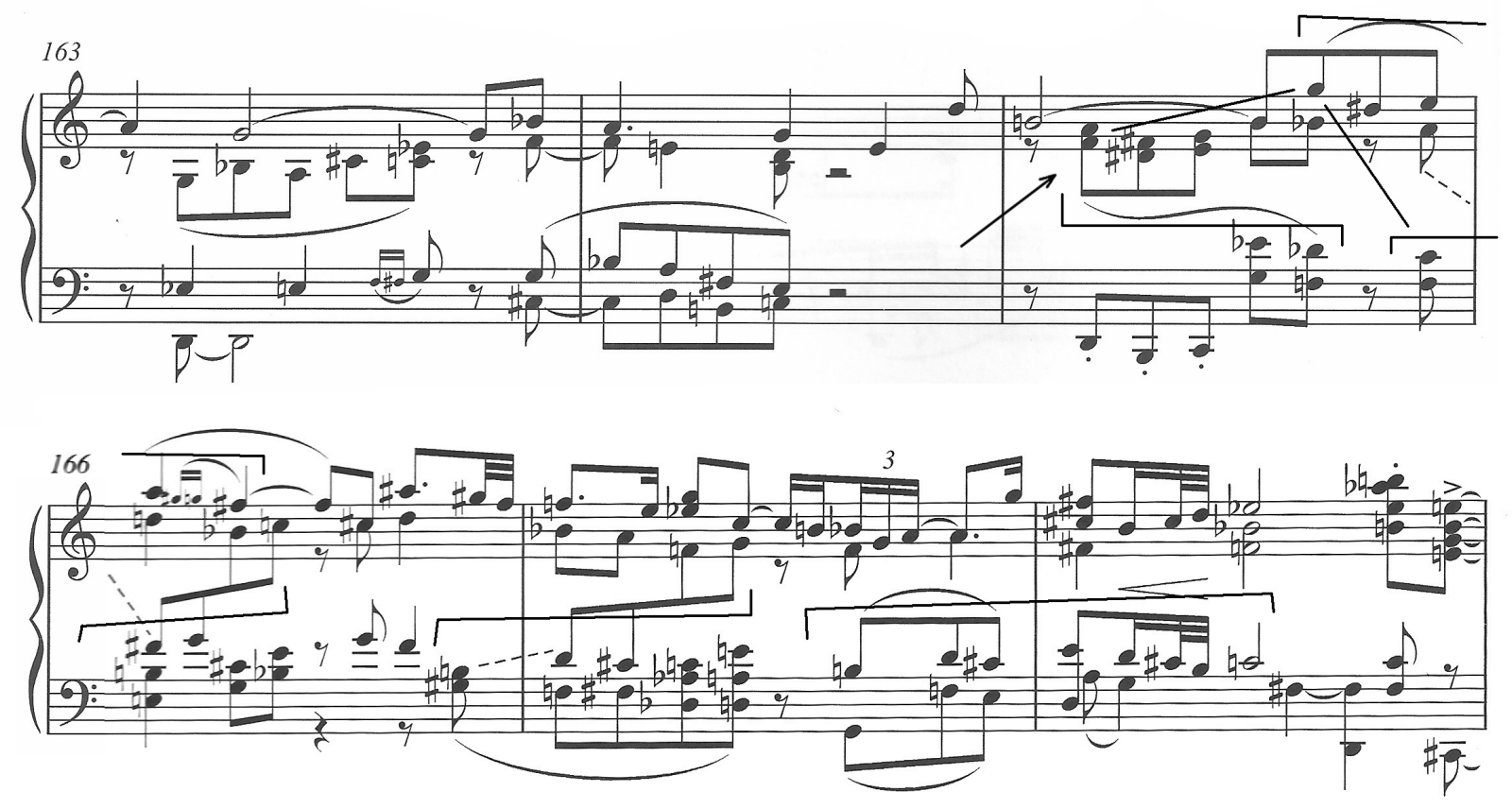

Example 9.2: Part II, Theme C, inversion and stretto, mm. 165-168

Theme A2 (mm. 173-178) appears as a transposition of Theme A2 in the Exposition of Part I (see Example 2). In comparison with Part I, where this theme begins on the B7 chord (m. 21), here it begins on the D7 chord (m. 173).

Theme B (mm. 179-191.3, see Example 5) is presented in a contrapuntal texture ( $\mathrm{mm}$. 179-180) and then transformed into improvisatory style passages (mm. 181-191). The meter switches from $12 / 8$ to $4 / 4$ twice in this section. Theme B is harmonically unstable. It begins in E minor (m. 179) and then moves through a variety of different key areas. Finally it comes back to the original key of E minor (m. 190.3).

Part II concludes with Theme C (mm. 191.4-195, see Example 8), also presented in a contrapuntal texture, giving the impression of a modified ternary design for Part II.

It is interesting to note that the last measure of Part II (m. 196) consists of only the note $\mathrm{Bb}$ in the bass which is followed by the note $\mathrm{E}$ in the bass as the beginning of Part III (m. 197). 
This tritone relationship between $\mathrm{E}$ and $\mathrm{Bb}$ will become one of the major harmonic and tonal aspects of Part III.

Part III (mm. 197-387)

Part III is written in sonata-allegro form.

\begin{tabular}{|c|c|c|c|c|}
\hline Part III: Sections & Measures & $\begin{array}{c}\text { Number of } \\
\text { measures }\end{array}$ & Timing & Length \\
\hline Exposition & $197-236$ & 40 & $10: 27-11: 23$ & $0: 56$ \\
\hline Introduction & $197-200$ & 4 & & \\
\hline Theme C & $201-216.1$ & 15 & & \\
\hline Theme D & $216.2-236$ & 21 & & \\
\hline Development & $237-316$ & 80 & $11: 24-13: 27$ & $2: 03$ \\
\hline Theme $\mathrm{C}$ material & $237-244.3$ & & & \\
\hline Transition 1 & $244.4-251.1$ & & & \\
\hline Theme $\mathrm{C}$ material & $251.2-275.3$ & & & \\
\hline Theme A1 & $255.3-260.1$ & & & \\
\hline Transition 2 & $275.4-279.3$ & & & \\
\hline Theme $\mathrm{C}$ material & 279.4-291 & & & \\
\hline Transition 3 & $292-295$ & & & \\
\hline Theme $\mathrm{C}$ material & $296-316$ & & & \\
\hline Recapitulation & $317-352$ & 36 & $13: 28-14: 21$ & $0: 53$ \\
\hline Introduction & $317-320$ & 4 & & \\
\hline Theme C & $321-332$ & 12 & & \\
\hline Theme D & $333-352$ & 20 & & \\
\hline Coda & & & & \\
\hline Theme $\mathrm{C}$ material & $353-387$ & 35 & $14: 22-15: 12$ & $0: 50$ \\
\hline
\end{tabular}

Chart 6

Part III is written in the tradition of Kapustin's virtuoso finales, utilizing the swing style in extremely fast Vivace tempo where the quarter note is equal to $176 \mathrm{bpm}$. Kapustin's tempo markings sometimes are set so high that it seems almost impossible to achieve. According to the composer, it might be advisable to play in a slightly slower tempo in order to get an appropriate 
swing feel into the music. ${ }^{105}$ It is a very intense section of the sonata, although due to the fast tempo, it is only 4 minutes and 45 seconds in length.

Part III begins with a four-measure Introduction and ends with a Coda which gradually fades away through the last 30 seconds of the work. Theme $\mathrm{C}$ represents the major thematic material for Part III. A new theme, Theme D, is introduced in the Exposition section presenting harmonic and tonal contrast to the predominant Theme C.

Part III: Exposition (mm. 197-236)

The Introduction section (mm. 197-200) sets up the character and the predominant swing style of Part III. Harmonically it is represented in the stable tonal area of E7.

Theme C (mm. 201-215) is written in the swing style and stresses the tritone relationship of $\mathrm{E}$ and $\mathrm{Bb}$ in the bass (mm. 201-204).

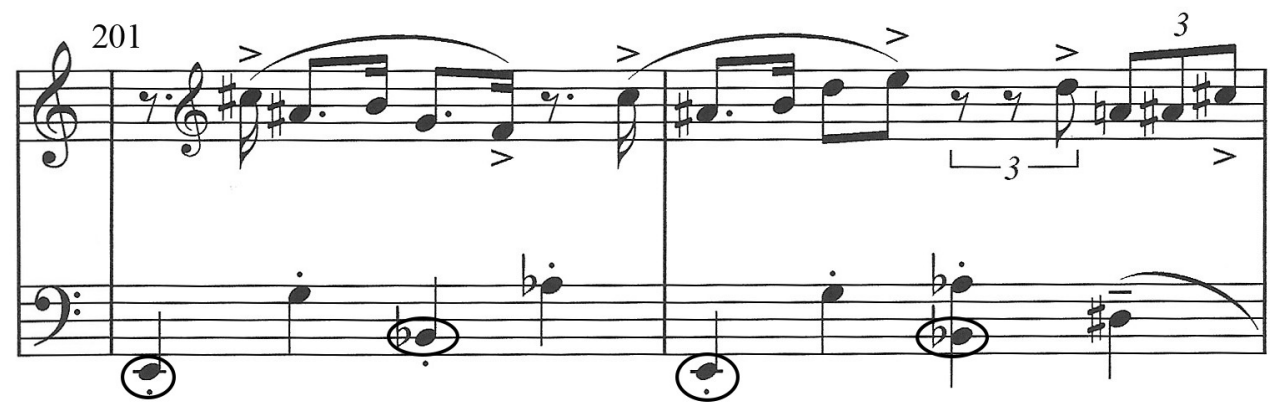

Example 10: Part III Exposition, Theme C, mm. 201-202

This is a tonally stable area, since Theme $\mathrm{C}$ stays within the $\mathrm{E}$ tonal area. Theme $\mathrm{C}$ also has the feature of stride piano technique where the bass and chordal accompaniment are performed in the left hand (mm. 209-215).

\footnotetext{
${ }^{105}$ Nikolai Kapustin, interview by author, Moscow, December 27, 2014.
} 
Theme D (mm. 216.2-236) represents the thematic and tonal contrast to Theme C.
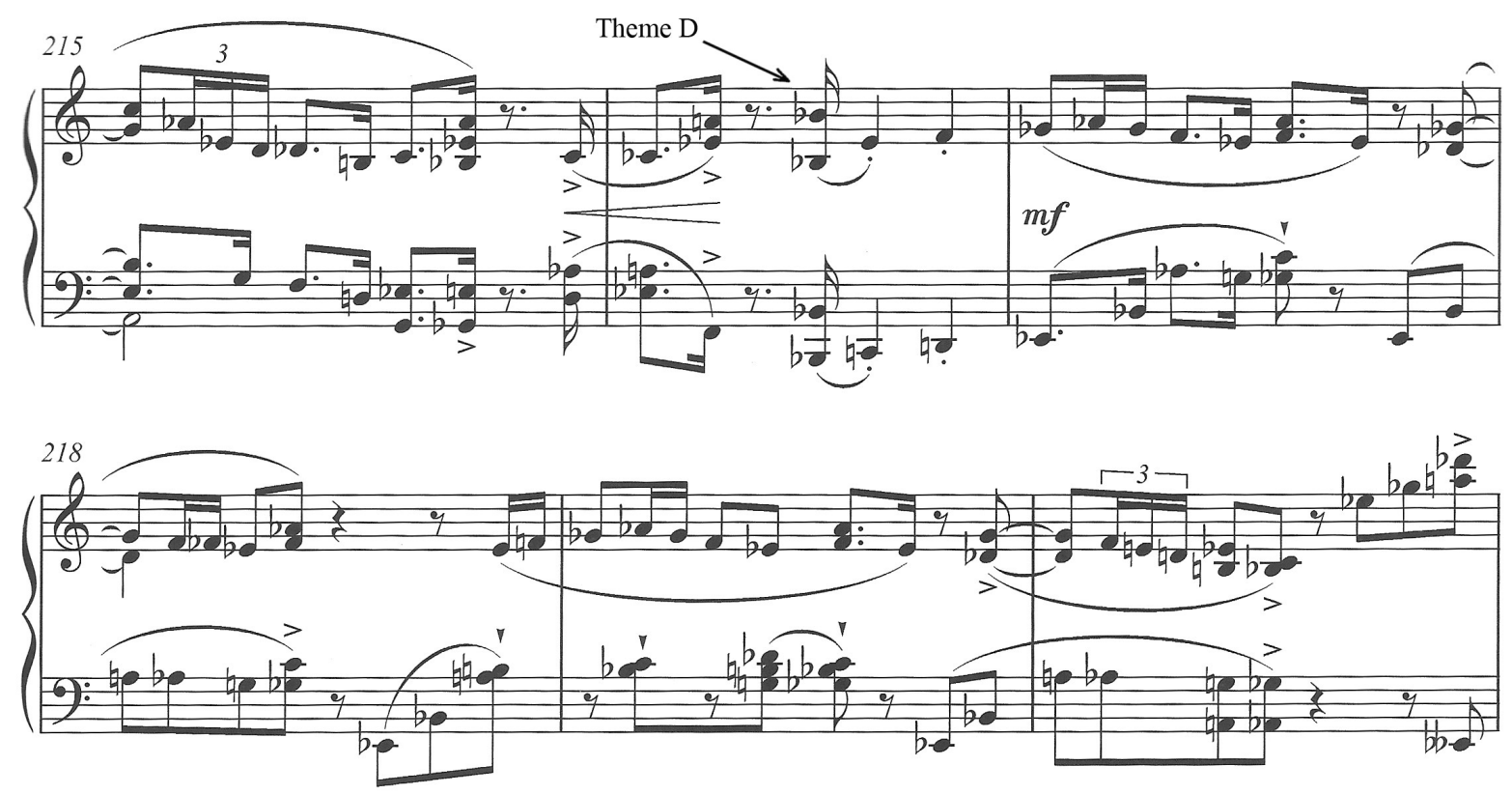

Example 11.1: Part III Exposition, Theme D, mm. 216.2-220

Theme D is motivically connected to the "Stella Theme," stressing the interval of p4 (see Example 5). Stylistically, it is an Eb minor blues. This tonally stable area of Eb minor can be interpreted as the key of the leading tone to the E tonal area, which is spelled enharmonically $(\mathrm{Eb}=\mathrm{D} \#)$.

Theme D is built upon a symmetrical four-measure phrase. It consists of four phrases. Phrase 1 (m. 216.2) and Phrase 3 (m. 224.2) are similar to each other and both written in the key of Eb minor. Phrase 2 (m. 220.3) represents a tonal contrast to Phrase 1, beginning in the key of $\mathrm{Gb}$ major which is the relative key of Eb minor. Phrase 4 (m. 228.3) is written in Eb major, the parallel key of the Eb minor. 
Phrase 4 is presented in the boogie-woogie style and imitates the sound of the Count Basie Band by the use of short syncopated chords in the high register and walking bass figure (m. 228.3-236).

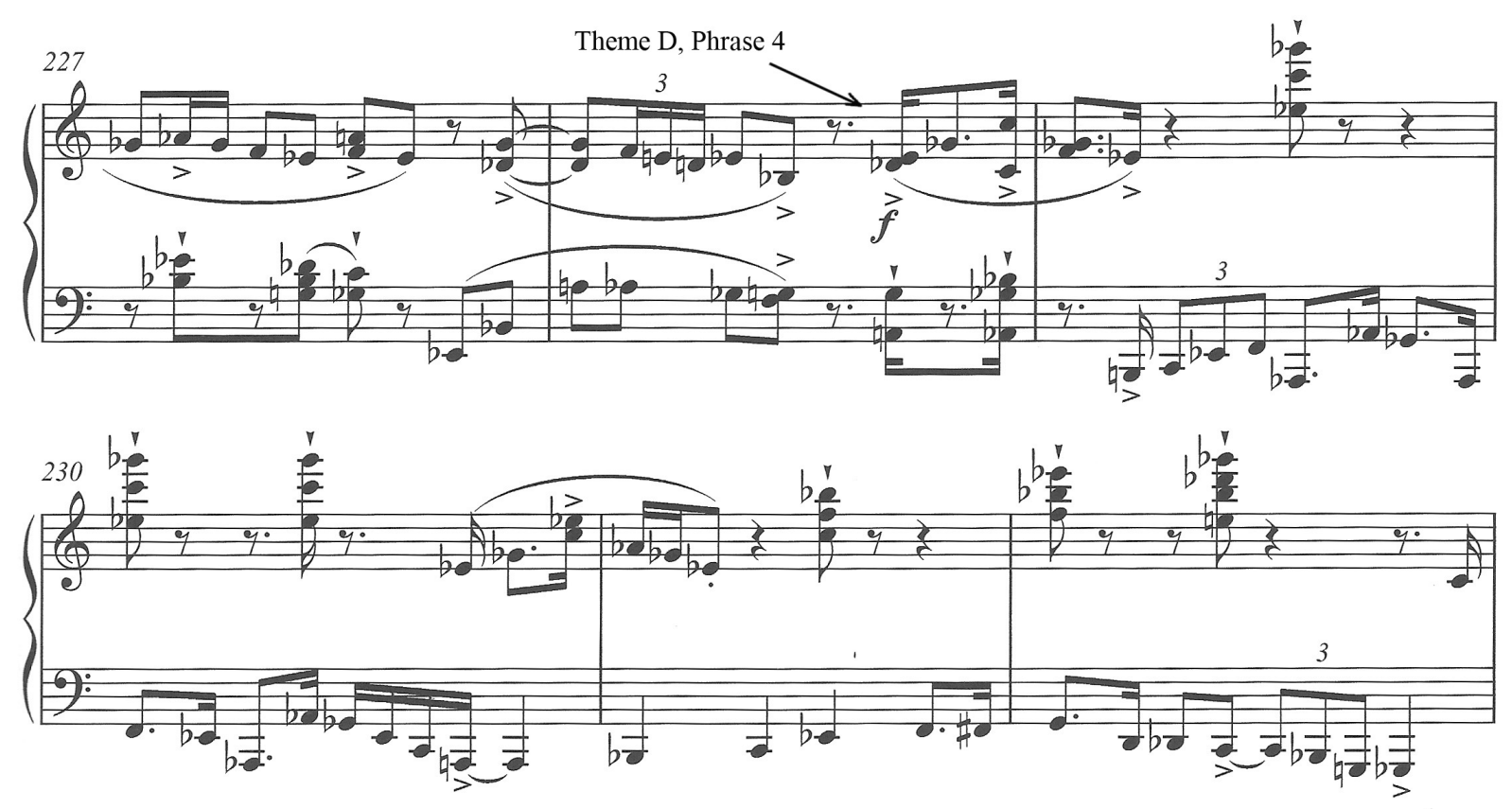

Example 11.2: Part III Exposition, Theme D, Count Basie style, mm. 228.3-232

Part III: Development (mm. 237-316)

The Development section is quite extensive. It is as long as the Exposition and Recapitulation sections together. Also, in comparison to the Development of Part I which is 47 measures in length, the Development of Part III is almost twice as long since it is 80 measures in length. There is a similarity between the Development sections of Part I and Part III. Both Developments are generally based upon one feature. The main material for the Development in Part I is Theme A1, presented in the motoric nature of Theme A2. In the same way, the main material for the Development in Part III is Theme C. However, the Development of Part III is 
constructed upon the numerous entries of Theme $\mathrm{C}$ in different stylistic and textural elaborations separated by three Transition sections (see Chart 6).

The Development section begins with Theme $\mathrm{C}$ which is first presented traditionally in the swing style (mm. 237-244, see Example 8).

After a six-measure Transition 1 (mm. 244.4-251.1), Theme C is presented in contrapuntal texture (mm. 251.2-267.3). It is a canon in octaves placed one beat apart.

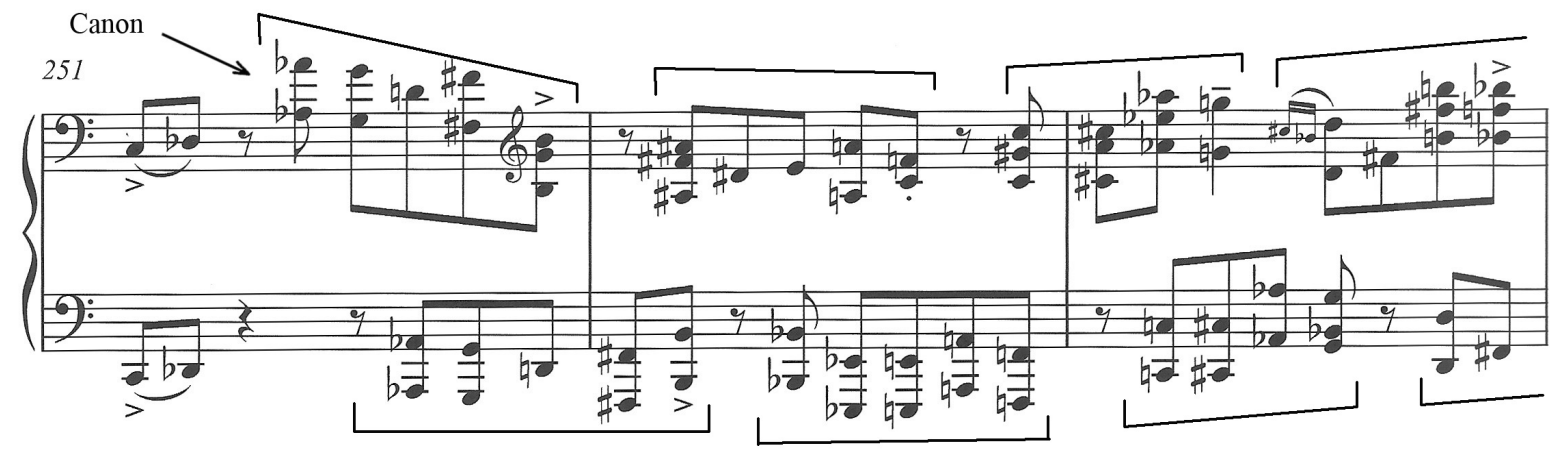

Example 12.1: Part III Development, Theme C, canon, mm. 251.2-253

The original five-note motive of Theme $\mathrm{C}$ gets thematically transformed and partially inverted. The material is presented in octaves in both hands which adds power and the spatial aspect to this section. The straight eighth-note figures in jazz-rock style (as performed by the composer) sound very affective and give dramatic contrast to the sonata where the general motion has been based on the swing style.

This entire section of the sonata ( $\mathrm{mm}$. 251-267) can be seen as a climax. It is supported by dynamic, dense texture, and rhythmic and harmonic complexity. 
Theme A1 in chordal texture is inserted in Theme $\mathrm{C}$. In addition, the $\mathrm{C} \#$ pedal point $(\mathrm{mm}$. 255.2-260.1) brings extreme intensity and excitement to the piece.

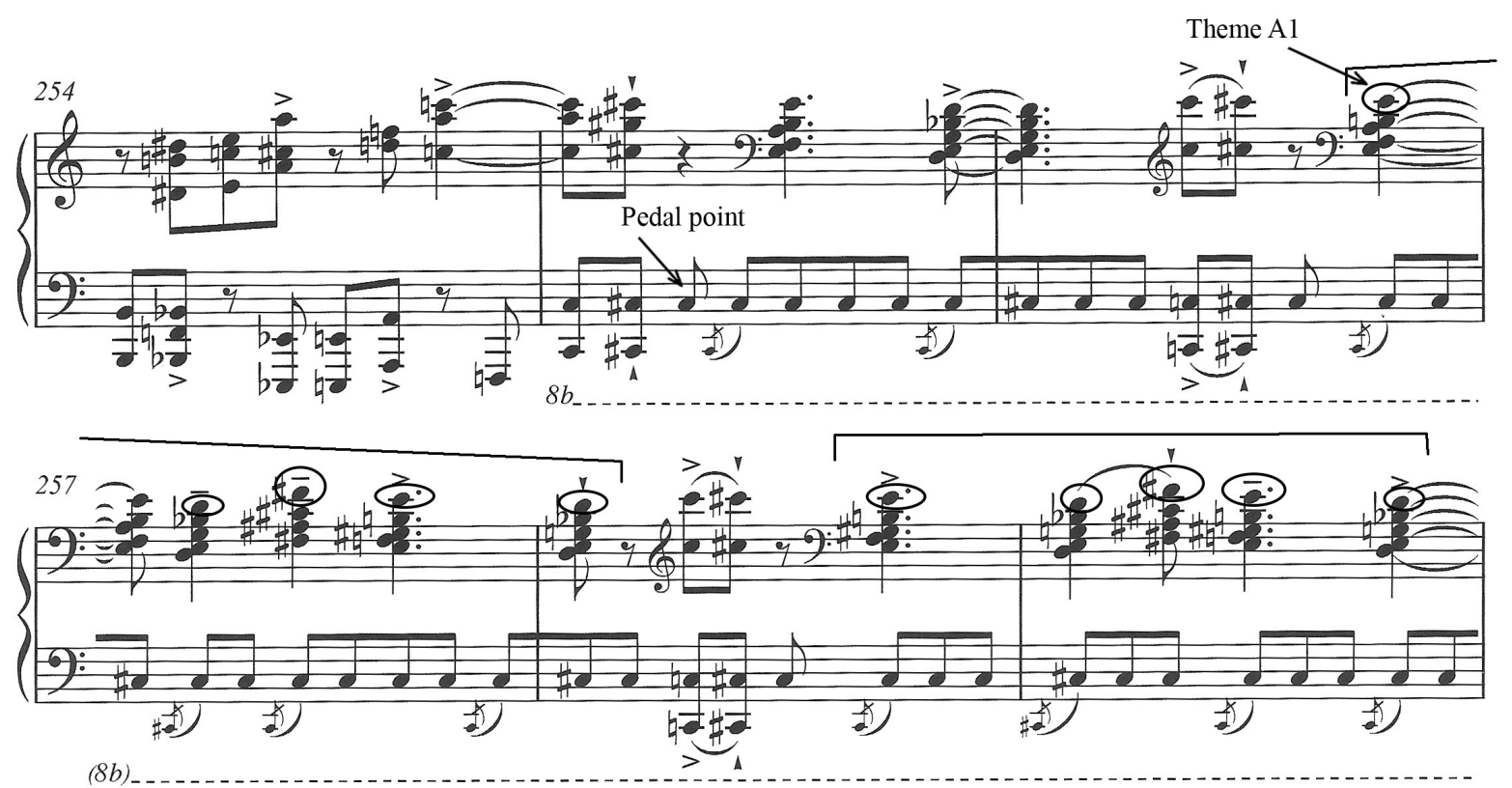

Example 12.2: Part III Development, Theme A1, pedal point, mm. 255.2-259

Going further, this section of the sonata can be seen as a "Golden section."

Proportionally, the "Golden section" may appear at the end of the third quarter of the piece which is in between of mm. 250-290 in this sonata. In our interview, Kapustin mentioned: "The Golden section is very important moment in my works. Usually, I am trying to watch out for it and carefully control it.",106

Gradually the straight eighth-note motion changes to the swinging eighth-notes. Based on the score and the actual performance of the sonata by the composer, this change is indicated in m. 268. Here, the straight eighth-note motion is switched to the swing motion (notated as dotted eighth-note and $\left.16^{\text {th }}\right)$. Although, after listening and trying different versions, it feels right to the author to switch to the swing style earlier, in $\mathrm{m}$. 263. Since this whole section of the sonata can

\footnotetext{
${ }^{106}$ Nikolai Kapustin, interview by author, Moscow, December 27, 2013.
} 
be seen as a climax (mm. 251-267), the dramatic effect would be bigger with the swing style beginning a few measures earlier. In my interview with Nikolai Kapustin, we discussed this question and he agreed that the idea of switching the style earlier sounds very convincing and effective. ${ }^{107}$ This demonstrates another aspect of Kapustin's personality: on one hand, he marks precisely all nuances in his scores and expects them to be followed, but on the other hand, he is open to new interpretations of his music.

Theme $\mathrm{C}$ continues to utilize the swing style in the next section of the Development ( $\mathrm{mm}$. 267.4-275.2). Although this time it moves to a higher register and changes the dynamic level to "p." The four-measure Transition 2 (mm. 275.4-279.3) leads to the continuation of the swing idea in the middle register (mm. 279.4-291). This section is tonally unstable.

The four-measure Transition 3 (mm. 292-295) leads to one of the most fascinating sections of the sonata. The material of Theme $\mathrm{C}$ in the right hand is presented upon a 12-tone row in the left hand walking bass (mm. 296-306).

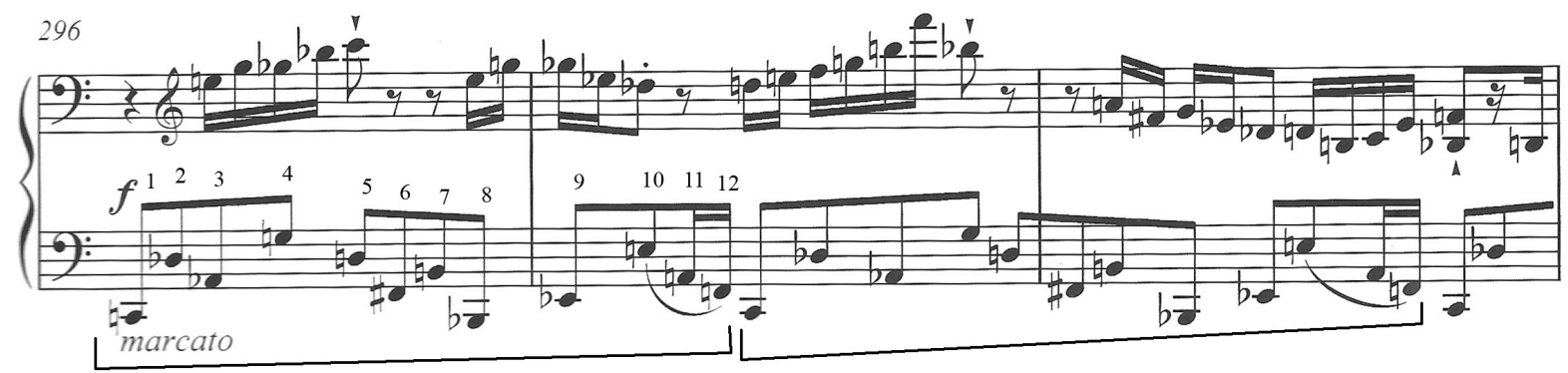

Example 13: Part III Development, Theme C, 12-tone row, mm. 296-298 ${ }^{108}$

This is one of the first examples where Kapustin experimented with serial technique. The row is repeated eight times and it takes five and a half beats to finish the row. It is constructed

\footnotetext{
${ }^{107}$ Nikolai Kapustin, interview by author, Moscow, December 27, 2014.

${ }^{108}$ According to the composer, in the published version the F natural that ends the row was mistakenly changed to $\mathrm{F} \#$.
} 
upon a succession of large intervals, such as $\min 9^{\text {th }}$, maj $7^{\text {th }}$, and $\min 6^{\text {th }}$ against the right hand motion in $2^{\text {nd }} \mathrm{s}, 3^{\text {rd }} \mathrm{s}$, and $4^{\text {th }} \mathrm{s}$.

The following material of the Development section presents Theme C rhythmically transformed and partially inverted $(\mathrm{mm}$. 307.3-314). It is presented in stretto and chordal texture in the right hand upon the octave settings in the left hand.

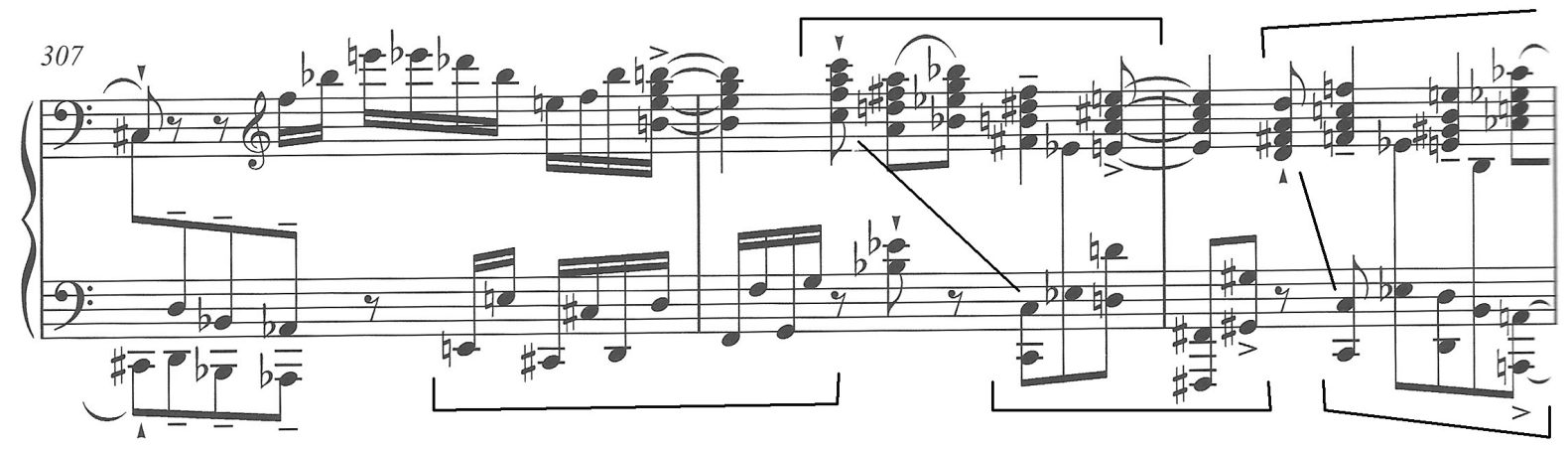

Example 14: Part III Development, Theme C, inversion and stretto, mm. 307.3-309

The last two measures of this intense Development (mm. 314.4-316) Theme C appears in the improvisational character, similar to Theme A1 in Part 1 . Stylistically it serves as a link to the swing style of the Recapitulation section. 


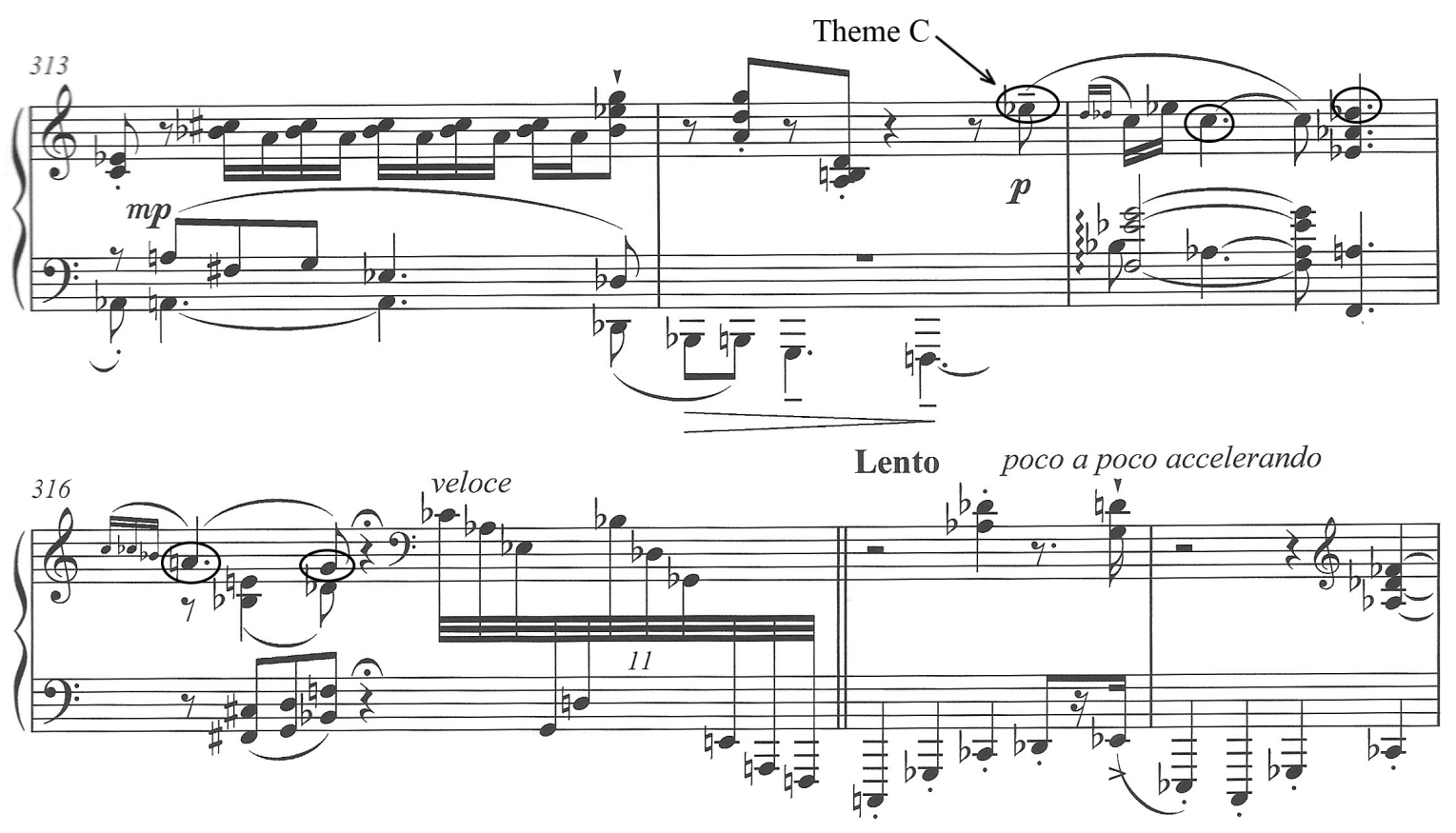

Example 15.1: Part III Development, Theme C, mm. 314.4-316.2

Harmonically mm.315-316 is V7/V-v-I progression in Eb maj/min without actual resolution to the tonic $(\mathrm{F} 7, \mathrm{Bb} \min 7)$. The resolution to the $\mathrm{Eb}$ tonal area will appear at the beginning of the Recapitulation section.

Thematically these two final measures of Theme C in Part III (mm. 314.4-316.2) mirror one of the final measures of Theme C in Part II (m. 194.4-195.3). The notes in the melody are identical, although the harmonic progression is different.

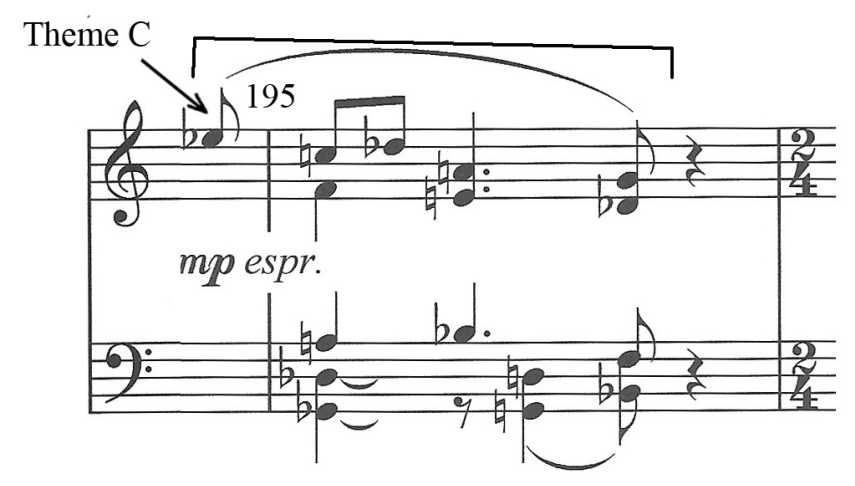

Example 15.2: Part II, Theme C, mm. 194.4-195.3 
Part III: Recapitulation (mm. 317-352)

The Recapitulation begins with a four-measure Introduction (mm. 317-320) in a very unusual way. It starts in the low register Lento poco a poco accelerando, creating the speeding up effect until the tempo reaches the $176 \mathrm{bpm}$ for the quarter note. Harmonically, it modulates from the $\mathrm{Eb}$ tonal area to the $\mathrm{C} 7$ tonal area $(\mathrm{m} .321)$ where Theme $\mathrm{C}$ is going to begin. Also, it is possible to trace the symmetry between two introductions in Part III: four-measure Introduction in the Exposition (mm. 197-200) and four-measure Introduction in the Recapitulation (mm. 317320).

Theme C (mm. 321-332, see Example 8) is written in a swing style and begins with the exact same melody notes in the right hand as in the Exposition of Part III. The only difference with the Exposition is that here Theme $\mathrm{C}$ begins with the $\mathrm{C} 7$ tonal area (m. 321) instead of E7 (m. 201). The tritone $\mathrm{C}-\mathrm{Gb}$ in the bass at the beginning of Theme $\mathrm{C}(\mathrm{mm} .321-322)$ is stressed in the same way as the tritone $\mathrm{E}-\mathrm{Bb}$ in the bass was stressed at the beginning of Theme $\mathrm{C}$ in the Exposition section (mm. 201-202).

Following the concept of traditional sonata-allegro form, where all the themes in the Recapitulation section are presented in tonic, Theme $\mathrm{C}$ moves back to the $\mathrm{E} 7$ tonal area (m. 326) and the E major tonal area, enharmonically spelled as $\mathrm{Fb}$ (m. 328.4).

Theme D (mm. 333-335, see Example 11.1) consists of four phrases, the same as in the Exposition. Phrase 1 begins with the tonal area of $\mathrm{C}$ minor (m. 333) and quickly switches to the Eb minor tonal area (m. 334.4), recalling the Eb minor tonal area of Theme $\mathrm{D}$ in the Exposition section (m. 216.2). Phrases 2, 3 and 4 are also repeating the tonal plan of the Exposition. This tonal aspect where both themes $(\mathrm{C}$ and $\mathrm{D})$ return to the tonic key in the Recapitulation strongly connects Part III to the traditional sonata-allegro form. 
Part III: Coda (mm. 353-387)

The Coda is built upon the material of Theme C (see Example 8). Harmonically it is centered on the E tonal area. Although, starting from m. 369, this tonal area is blended with the $\mathrm{Bb}$ tonal area. It sounds like the composer is not sure in which key he would like to finish the sonata. This section is rhythmically complex. The dynamic starts from " $p$ " and moves to "ppp" at the end of the sonata. The last gesture of the sonata is the exact motive of Theme $\mathrm{C}$ in a subcontra octave in the left hand while the right hand is reaching to the limits of the piano in the fourth octave (mm. 385.4-386.2).

This Coda sounds unusual from the traditional standpoint because it creates a fading out effect together with expanding the spatial distance between the hands, giving the visual effect of disappearance. However, from the jazz perspective, this effect is a common device for performers. This ending can be also expressed as a "tongue-in-cheek" Coda because it shows the element of humor in music. Indeed, the composer himself has a great sense of humor! In our interview Kapustin acknowledged the fact that the ending of the sonata was not so serious. ${ }^{109}$

Both the Introduction to the Recapitulation of Part III (mm. 317-320) and the last section of the Coda of Part III (mm. 369-387) create a visual effect. In the case of the Introduction it is the accelerando (coming towards you), and in the case of Coda it is the effect of diminuendo (going away).

The Coda of Part III has a melodic "mirror" effect of disappearance. The last two pitches, $\mathrm{E}$ and $\mathrm{Bb}$, at the end of the Coda (mm. 386-387) "mirrors" the notes $\mathrm{Bb}$ and $\mathrm{E}$ at the beginning of the Introduction of Part III (mm. 196-197). This gives the symmetrical aspect to the Part III as a whole.

\footnotetext{
${ }^{109}$ Nikolai Kapustin, interview by author, Moscow, December 27, 2014.
} 


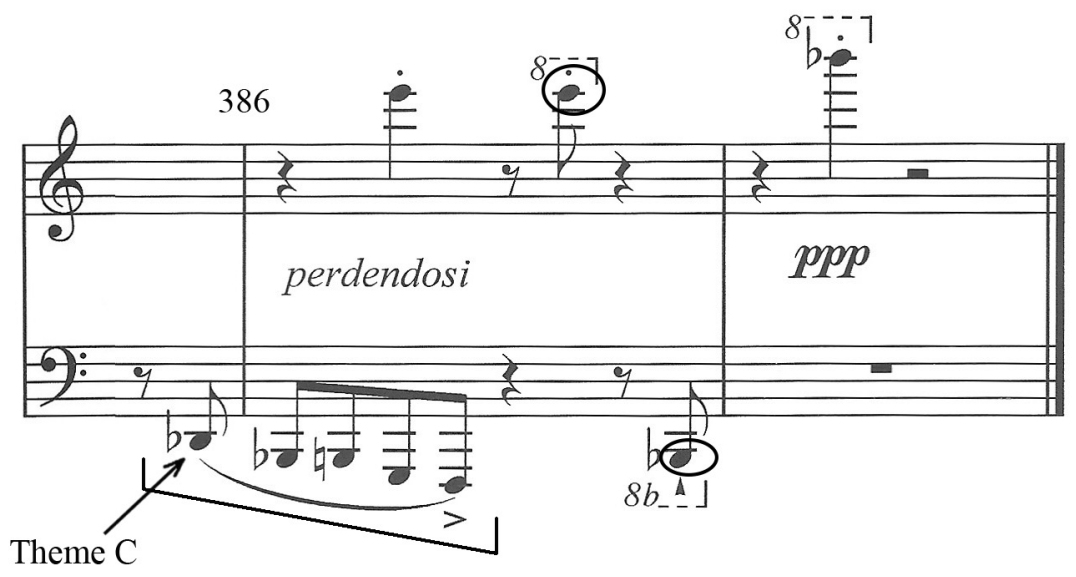

Example 16.1: Part III, Coda, mm. 385.4-387

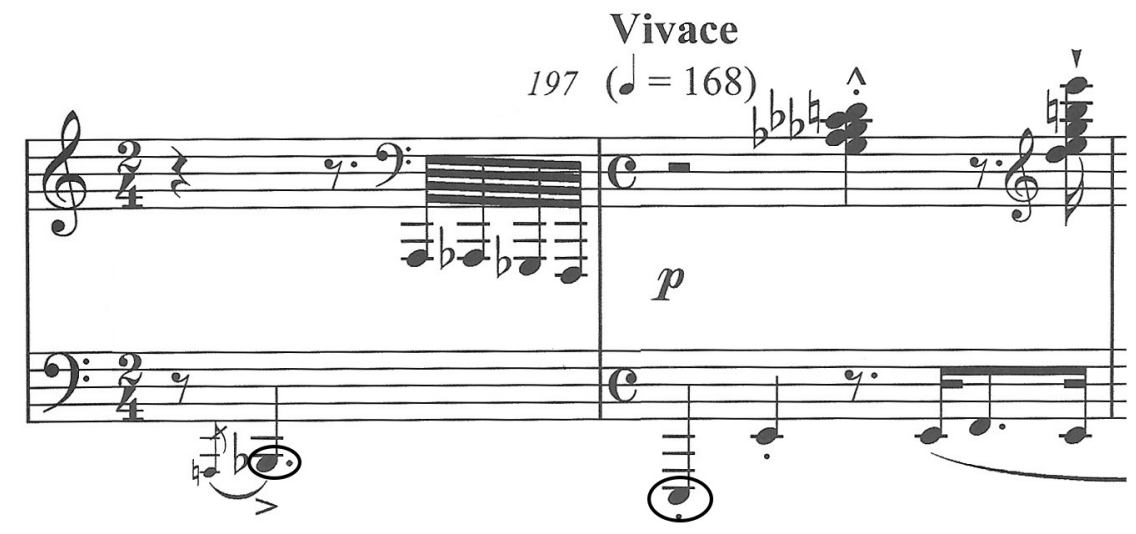

Example 16.2: Part III, Introduction, mm. 196-197

The sonata ends on the note $\mathrm{Bb}$ in both hands. The composer is reaching the limits of the piano distancing both hands seven octaves apart. 
To summarize:

First, Sonata No. 3 is written in three-part form where Part I and Part III are written in a modified sonata-allegro form and the Part II has a modified ternary design.

Second, the sonata consists of four major ideas (Theme A group of themes, B, C, and D), which are motivically close to each other and may potentially be derived from the quote of "Dies Irae." The most active of all four is Theme $\mathrm{C}$ and it functions as the main material for Part III.

Third, three major characters are introduced right from the beginning of the sonata: improvisatory (Theme A1), motoric (Theme A2), and swing style (Theme A3). The lyrical Theme B belongs to the improvisatory side, and Themes $\mathrm{C}$ and $\mathrm{D}$ are both written in the swing style.

Fourth, the sections of strong tonality occur mostly in Part III. Both Themes C and D are tonally stable, especially the Eb blues section of Theme D. In other words, the general harmonic motion of the sonata is going from unstable tonal areas to more stable tonal areas.

Fifth, the most unique characteristic of the sonata is the use of the 12-tone row in the Development section of Part III within the swing stylistic concept of the sonata.

Sixth, connection to the traditional sonata-allegro form may be seen in the three major sections which are Exposition, Development, and the Recapitulation. The "mirror" Recapitulation as well as tonal concept of coming back of the home key in the Recapitulation also directs us to the concept of the traditional sonata-allegro form. Both themes come back eventually to the tonic in the Recapitulation section which is the tonal area of E7 for Theme C and the tonal area of the $\mathrm{Eb}$ minor for Theme $\mathrm{D}$. This connection may be seen also in the contrast between Themes A and B in Part I and Themes C and D in the Part III. 
Performance suggestions:

First, Sonata No. 3 is one of the pieces which pianistically fits well into your fingers. In the interview with Harriet Smith, Nikolai Kapustin said: "All piano music has to be composed at the keyboard otherwise you can write very strange things. If I didn't play I wouldn't be able to compose - when you're a performer you know how to make things easier for the player." ${ }^{\prime 10}$ The correct fingering is one of the major questions that may appear during the work in this sonata. Kapustin's music has a lot of similar turns that may go into different sections of the sonata, for example, m. 195 and 316, m. 210 and 214, m. 245 and 276. The consistent use of proper fingering is potentially going to help in developing muscle memory and therefore aid in the process of memorization. Additionally, proper fingering will help to avoid "jumping" though the different sections of the sonata since the material itself contains a large amount of similar places.

These two examples (Examples 17.1 and 17.2) show the difference in fingering in two similar episodes. In Example 17.1 it is suggested to use finger four in the right hand on the strong beat (m. 211.1) where in the Example 17.2, in a similar setting, it is suggested to use finger five in the right hand on the strong beat (m. 215.1).

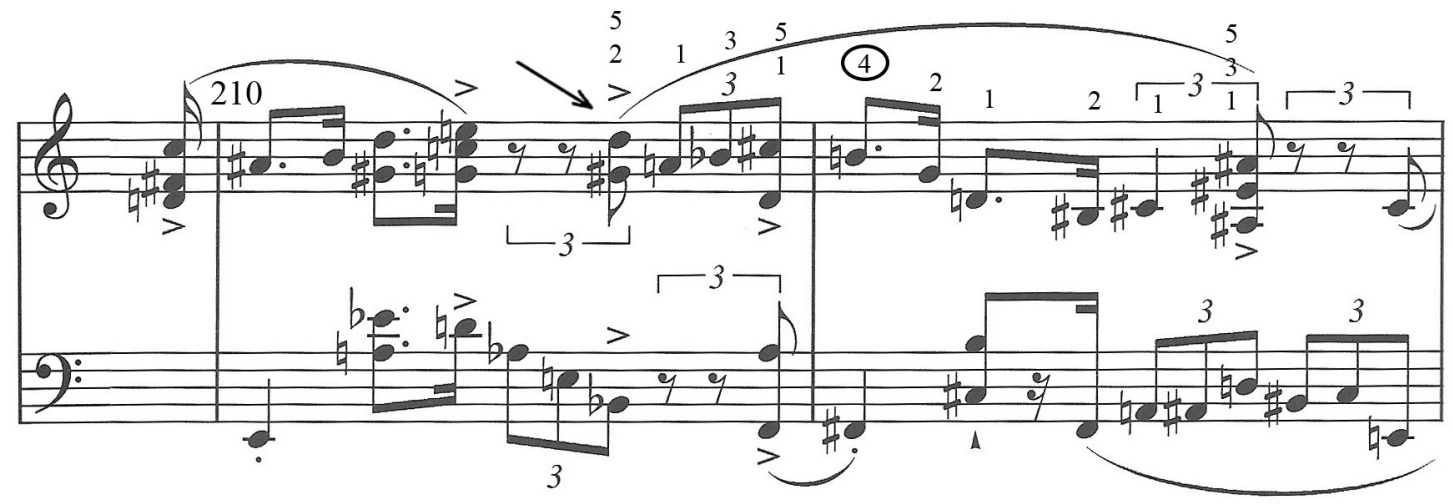

Example 17.1: Part III Exposition, Theme C, fingering, mm. 210-211

\footnotetext{
${ }^{110}$ Smith, 50.
} 


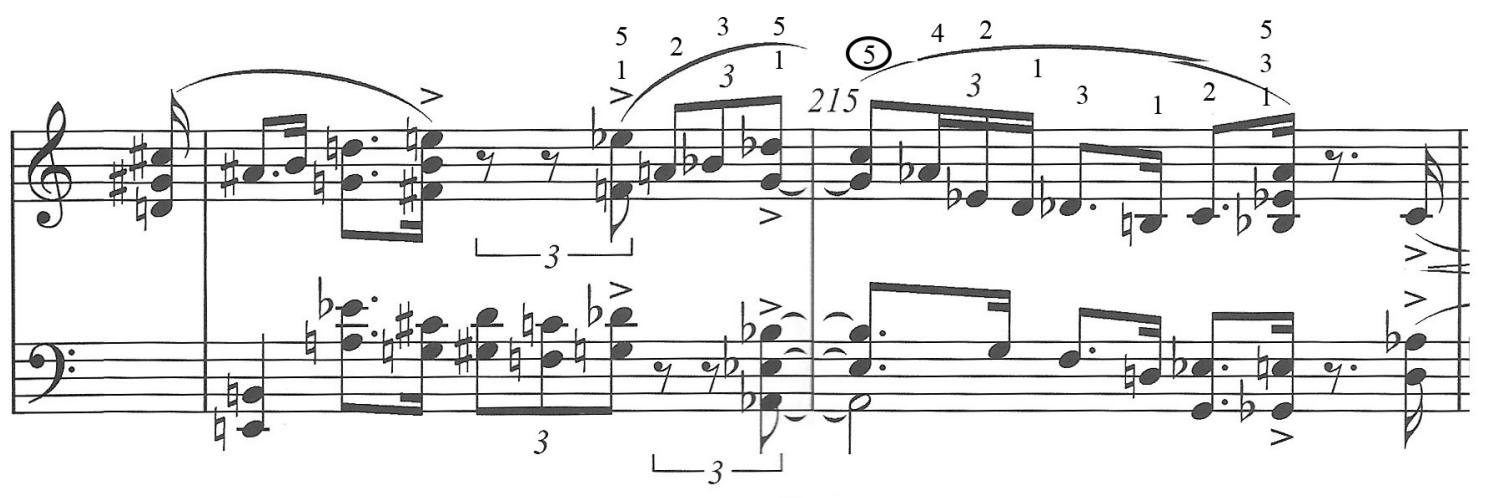

Example 17.2: Part III Exposition, Theme C, fingering, mm. 214-215

Second, the understanding of the swing style plays a crucial role in the performance of this work. In my opinion, the performer should be able to understand the basic ideas of jazz harmonic language, jazz rhythms, and preferably be able to improvise. The improvisational skills give the performer the ability to understand the jazz music from the inside.

In conclusion, Kapustin allows the performer some freedom; it is a freedom of interpretation. The performer is able to choose whether he prefers to play straight eighth-notes or swing in some sections (mm. 264-267) and to choose the proper tempo (m. 197). The ability to make these decisions serves as the "entrance exam" for the performer in order to have a successful and interesting interpretation. In addition, the recordings of "Kapustin plays Kapustin" may give some important directions and guide the performer through the music especially at the early stage of learning the material. 


\section{Chapter Seven}

\section{Summary and Conclusion}

Nikolai Grigorievich Kapustin was born on November 22, 1937 in the Ukraine. He moved to Moscow in 1952 to study in the Musical College as a classical pianist. Luckily, he was accepted to the class of Avrelian Rubakh. In the summer of 1956 Nikolai Kapustin graduated from Music College and entered the Moscow Conservatory. Kapustin was accepted to the class of legendary pianist, teacher, composer and author Alexander Goldenweiser. During the years of study in the Conservatory in late 1950's Kapustin started to work as a jazz pianist, arranger, and composer. One of the important landmarks in his career as a composer was his performance in July 1957 of his own piece, Concertino for Piano and Orchestra, Op. 1, in the $6^{\text {th }}$ World Festival of Youth and Students in Moscow.

A new period of Kapustin's life started in 1961 when he started to collaborate with the Oleg Lundstrem Big Band. During the years of 1961 to 1972 Kapustin was writing music for this big band and performing as a pianist. At the end of the 1960's, touring with the Oleg Lundstrem Big Band, Kapustin met his future wife Alla Baranovskaya. In January 1969 Nikolai Kapustin and Alla were married. Having a family, Kapustin could not continue to tour extensively with the Lundstrem Big Band. Therefore, beginning from 1972, Kapustin started to work with Boris Karamishev "Blue Screen" Orchestra in Moscow. The function of this orchestra was to broadcast live over television and radio. This orchestra also toured the USSR and did recording sessions. Later in 1977 Kapustin joined the State Symphonic Orchestra of Cinematography. The function of this orchestra was the recording of music for the cinema.

Starting from 1984 Kapustin rejected the official work and decided to dedicate himself exclusively to composition. One of his trips abroad happened in 2000 when Kapustin travelled to England. There were two reasons for this trip: first, to attend the formation of "Kapustin's 
Society" and, second, to attend the Western premiere of his Piano Sonata No. 2, Op. 54, by Marc-Andre Hamelin, one of most respected modern-day pianists.

Russian audiences also appreciate the music of Nikolai Kapustin. There have been three concerts in Russia dedicated to the works of Nikolai Kapustin. The first concert was dedicated to Kapustin's $70^{\text {th }}$ birthday and took place in Gnesina College (Moscow) in December 2007. In March 2009, the second concert took place in the Chamber Hall of the Moscow Philharmonic Society, and in December 2011 the third took place in the Arkhipov's Musical Salon in Moscow.

It is interesting to note that Kapustin has had no official training in composition or in jazz piano. He is a self-taught composer and a self-taught jazz pianist. While Kapustin did not study jazz piano he developed as a jazz pianist listening to and transcribing the compositions that he heard on the radio station "Voice of America."

Kapustin's musical style represents the idiomatic fusion of the classical and jazz traditions. Kapustin's music is unique and different from other composers because he is not only trying to fuse these two styles together, but also create something new on the foundation of these concepts.

There are three major factors which indicate the influence of Classical music on the music of Kapustin. They are the use of the genres and forms of classical music, the compositional process, and compositional techniques. Kapustin uses classical genres such as sonata, concerto, symphony, string quartet, piano trio, suite, prelude and fugue, and classical forms such as variations, sonata-allegro, rondo, and more.

The compositional techniques include thematic transformation, motivic development, and contrapuntal devices such as stretto, canon, and inversion. Classical compositional techniques are 
utilized in his approach to composition which is not to write something spontaneous, but to work with the musical material to improve it, to make it perfect.

Jazz influences in the music of Kapustin may be traced from many different sources. First, his music is much influenced by performances of some of the greatest, most innovative jazz pianists in history such as Oscar Peterson, Art Tatum, Herbie Hancock, and Bill Evans. Second, Kapustin utilizes the styles of swing, rag-time, blues, be-bop, stride, and boogie-woogie in his compositions. Third, the harmonic, rhythmic, and textural complexity of Kapustin's music reflects his influence from jazz music.

Russian music influences on the music of Nikolai Kapustin may be traced from the music of Rachmaninov, Scriabin, and Medtner. The motivic derivation of Kapustin's music connects it to the music of Scriabin. Also, in our interview Kapustin noted: "There is something from the Russian nature in my music." 111 Indeed, the images of Russian nature can be heard in his piano works, for example in the slow movements of piano sonatas.

Kapustin's music appears to be improvisation in a jazz style. However, his music is always written out. The composer wants control over the performance and does not allow the performer to improvise. There are two reasons for this statement. First, Kapustin believes that "structural considerations are more important than the suggesting spontaneity of jazz."112 Second, Kapustin considers improvisation as being not perfect, but as raw material that needs to be improved. ${ }^{113}$

Looking at the entire output of the composer, the genres emphasized vary from one decade to another. For example, in the 1960's he was writing music for big band. At this time

\footnotetext{
${ }^{111}$ Nikolai Kapustin, interview by author, December 27, 2014.

112 Anderson, 96.

${ }^{113}$ Nikolai Kapustin, interview by author, December 27, 2013.
} 
Kapustin was working as a jazz pianist and composer in the Oleg Lundstrem Big Band. The music of the 1970's was inspired by the Hollywood movies of the 1940's. During that time Kapustin was working with the Boris Karamishev "Blue Screen" Television and Radio Orchestra and State Symphonic Orchestra of Cinematography. Starting from the 1980's, Kapustin began writing primarily piano music. Kapustin himself considers the beginning of the 1990's as his short modern period. This style is signified by the diversity of different musical influences, experimentation, and, as a result, innovation of musical style. In the 2000's Kapustin continued to write solo piano music as well as chamber works.

From the whole output of Kapustin's works, the twenty piano sonatas hold their special position in defining his career as a composer. The twenty piano sonatas were composed during the years 1984 to 2012. It was the time when Nikolai Kapustin began writing virtuoso compositions for solo piano. Kapustin composed ten sonatas before 2000 and the other ten sonatas after 2000 .

The majority of the sonatas are 14-17 minutes in length with the exception of three sonatas (Sonata No. 2, Op. 54, Sonata No. 7, Op. 64, and Sonata No. 15, Op. 127), which are longer. The number of movements varies from one to four with the predominance of three to four movement works.

Most of Kapustin's sonatas are based on a dramatic contrast between movements. The first movement may represent the sketch of different musical ideas. It could be sectional or written in the sonata-allegro form. The middle movements are always slow, choral-like, and dreamy in mood. Kapustin's finales are always virtuosic and perpetual motion in character, full of energy and drive. 
According to the composer, there are only two quotes from earlier music to be found in the set of twenty piano sonatas. One is a quote of the "Dies Irae" theme in the Piano Sonata No. 3, Op. 55 and the second is a quote of Beethoven's Piano Sonata "Pathetique," Op. 13 in the Piano Sonata No. 9, Op. 78.

The Piano Sonata No. 3, Op. 55 was composed in 1990. It represents the beginning of Kapustin's short modern period. Starting from this work Kapustin stopped indicating the key signature, started to use more complex harmonic and rhythmic language, and experimented with serial techniques. Sonata No. 3 is a large one-movement work and it is fifteen minutes in length. ${ }^{114}$ It is possible to subdivide it into three separate parts.

Part I is written in the modified sonata-allegro form with "mirror" Recapitulation. It presents a kaleidoscope of different moods: improvisatory Theme A1, technical and very chromatic Theme A2, swing style Theme A3, lyrical and retrospective Theme B, and later on, the motoric nature of Theme C. One of the most unusual characteristics of the sonata is that Part I contains a quote of the "Dies Irae" theme. All the major themes of the sonata are motivically connected to the "Dies Irae," which may bring us to a conclusion that the majority of the themes are derived from the quote of "Dies Irae."

Part II is an equivalent of the slow movement in the traditional three-movement sonataallegro form. It is written in a modified ternary form. Part II is characterized by the use of contrapuntal texture and compositional devices such as stretto, canon, and inversion. Formally, it contains all of the major themes from Part I, which may direct us to a conclusion that Part II has the characteristics of a Development in the scope of the whole sonata.

Part III is written in a modified sonata-allegro form and it sounds like one of Kapustin's virtuoso finales. It is totally dedicated to the swing style, although it has a section in jazz-rock

\footnotetext{
114 Timing of the Piano Sonata No. 3 based on the recording by Nikolai Kapustin.
} 
style as well as a section where Kapustin experiments with serial techniques. The major thematic material of Part III is Theme C. Although a new theme, Theme D is introduced in the Exposition of Part III, presenting the blues idea. Themes C and D function as contrasting material in a similar manner to Themes A and B in the traditional sonata-allegro form.

The most unique characteristic of the sonata is the use of the 12-tone row in the Development section of Part III within the swing stylistic concept of the sonata.

The tonality is not clearly established in the sonata in a traditional sense. We may talk about the tonal centers that present some tonal connections by using the motives, ii-V-I progression, and the independently standing Dominant $7^{\text {th }}$ chords. The general harmonic motion of the sonata is going from unstable tonal areas to more stable tonal areas. Therefore, the sections of strong tonality occur mostly in Part III.

The connection to the traditional sonata-allegro form may be seen in three major sections, which are Exposition, Development, and Recapitulation, contrast between two major themes (Themes A and B in Part I and Themes C and D in Part III), and the tonal concept of coming back to the home key in the Recapitulation section.

Nikolai Kapustin is one of the best living composers of our time. He is also one of the few composers playing and recording his own music. His famous recordings "Kapustin plays Kapustin" make a significant contribution to the process of learning his music. His performances can give valuable directions for our own interpretation. On one hand, Kapustin indicates in the score very precisely all nuances about his music: tempo markings, rhythm, style, dynamic, articulation, and sometimes even fingering. On the other hand, Kapustin is also open to a new interpretation of his music, he is not against changing the tempo, agogical nuances, and even style if it seems appropriate to him. This means that the composer is not afraid to hear his music 
in different interpretations. Undoubtedly, this liberal approach towards the performer gives a lot of respect to the composer.

What kind of performer is Kapustin's demanding music written for? This is a very interesting question because his music needs many different aspects and skills from the performer. First, the performer has to have very good technical skills, since most of Kapustin's music is oriented toward a virtuoso type of pianist. Second, the performer has to not only understand the jazz harmonic and rhythmic language but also be able to follow it through the music during the actual performance. This is one of the most difficult tasks since Kapustin's music is very intense harmonically with tonal centers that may change in each measure. Third, it would be helpful if the performer was acquainted with the Russian side of Kapustin's music.

The question that will conclude our topic may be introduced as - will the music of Nikolai Kapustin survive within the next fifty years? I believe that great music will survive. Kapustin's music has no chance to be forgotten. There are a few reasons for this statement. First, Kapustin is a Russian composer who united an American style, classical genres, and Russian musical tradition. He then raised his music to an international level of acceptance. Second, he completely dedicated himself to composition and is confident about his musical abilities. Third, in one of the few interviews Kapustin admitted: "I think the popularity came because of the pianists who performed my music - Nikolai Petrov, Nikolai Lugansky, Stiven Osborn, MarcAndre Hamelin, John Salmon, Vadim Rudenko."115 This means if musicians of this stature will continue playing the extraordinary music of Nikolai Kapustin it will never be lost or forgotten.

The author is a Russian born classical pianist and also trained as a jazz vocalist and jazz pianist. I can observe research into the music of Kapustin both as a jazz performer and a classical

${ }^{115}$ Antonina, 40. 
performer. It is interesting to note that American researchers concentrate their attention more on the jazz side, which belongs to the American culture. Russian researchers, in contrast, pay more attention to the Classical side and to Kapustin's deep connection to the Russian culture. This is understandable. Although, standing right in the middle of these two opposite schools of thought, it is necessary to point out that we cannot ignore either of these two perspectives. Both approaches are necessary to develop a better understanding of the music of Nikolai Kapustin. I may compare the music of Nikolai Kapustin with the nature of diamonds - looking at it from the different angles the different colors may appear to the performer's imagination. That is the beauty of his music - being always different and always new! 
Bibliography

Encyclopedias

Grigor'yeva, Alla Vladimirovna. "Kapustin, Nikolay Girshevich.” In Grove Music Online. Oxford Music Online.

“Kapustin, Nikolay Girshevich.” In Dzhaz XX vek: Entsiklopedicheskii spravochnik [Jazz of 20th century: An encyclopedic guide], edited by Vladimir Feiertag, 192. Saint Petersburg: Skifia, 2001.

"Kapustin, Nikolay Girshevich.” In Dzhaz XX vek: Entsiklopedicheskii spravochnik [Jazz of 20th century: An encyclopedic guide], 2nd ed., edited by Vladimir Feiertag, 238-239. Saint Petersburg: Skifia, 2008.

Dissertations and Theses

Creighton, Randall J. "A Man of Two Worlds: Classical and Jazz Influences in Nikolai Kapustin's Twenty-Four Preludes, Op. 53." D.M.A. diss., The University of Arizona, 2009. http://search.proquest.com/docview/304846309? accountid=2837.

Kim, Eun-Joung. "A Style and Performance Guide to Selected Piano Toccatas, 1957-2000." D.M.A. diss., University of Cincinnati, 2013. http://search.proquest.com/docview/1458303509?accountid=2837.

Mann, Jonathan Edward. "Red, White, and Blue Notes: The Symbiotic Music of Nikolai Kapustin." D.M.A. diss., University of Cincinnati, 2007. http://search.proquest.com/docview/304883419?accountid=2837.

Roberts, Jonathan Eugene. "Classical Jazz: The Life and Musical Innovations of Nikolai Kapustin." D.M.A. diss., The University of Alabama, 2013. http://search.proquest.com/docview/1448872255?accountid=2837.

Steele, Susannah. "Nikolai Kapustin's ‘Ten Bagatelles,' Op. 59." D.M.A. diss., The University of North Carolina at Greensboro, 2013. http://search.proquest.com/docview/1426396425?accountid=2837.

Ursova, Tetyana. "Interpreting Cycles of Preludes and Fugues by Soviet Composers: Problems of Performance and Perception." Ph.D. diss., University of London, Goldsmiths College, 2009.

Available through EThOS British Library Electronic Theses Online Service http://ethos.bl.uk 
Wang, Ruby. "Fusion of Classical Virtuosity and Jazz Techniques in the Etudes of Nikolai Kapustin: 'Eight Concert Etudes,' Op. 40, and 'Five Etudes in Different Intervals,' Op. 68." D.M.A. diss., University of South Carolina, 2014.

http://search.proquest.com/docview/1540791946?accountid=2837.

Whitehead, Annalee Schultz. "A Global Sampling of Piano Music from 1978 to 2005: A Recording Project.” D.M.A. diss., University of Maryland, College Park, 2011. http://search.proquest.com/docview/1223343026?accountid=2837.

Book

Samson, Jim. Music in Transition: A Study of Tonal Expansion and Atonality, 1900-1920. New York: W.W. Norton, 1977.

Periodicals

Anderson, Martin. “Nikolai Kapustin, Russian Composer of Classical Jazz.” Fanfare 24, no. 11 (September/October 2000): 93-98.

De'Ath, Leslie. 'Nikolai Kapustin - A Performer's Perspective." MusicWeb International (June 2002). Accessed June 20, 2014. http://www.musicweb-international.com/classRev/2002/Jun02/Kapustin.htm.

Gafarov, Iskander. "Nikolai Kapustin. Shtrihi k portretu" [Nikolai Kapustin. Touches to the portrait]. Molodoi uchionii, no.2 (2013): 444-447. Accessed June 15, 2014. http://www.moluch.ru/archive/49/6252.

Isacoff, Stuart. "Marc-André Hamelin Plays the Wild and Jazzy Music of Nikolai Kapustin." Piano Today 24, no. 4 (2004): 4-6.

Maga, Antonina. "Vse moi proizvedenia - s dzazovym akcentom: Beseda" [All of my work is marked with a jazz emphasis': A conversation]. Muzikalnaya jizn, no.10 (October 2008): $39-40$.

Smith, Harriet. "Bridging the Divide: The Russian Composer Nikolai Kapustin." International Piano Quarterly 4, no.13 (Autumn 2000): 54-55.

Websites

Breemer, Chris. "Nikolai Kapustin.” Accessed September 13, 2014. http://www.pianosociety.com/cms/index.php?section=1454. 
Fedorov, Ivan. "ClassicalForum.ru." Accessed September 23, 2014. http://www.classicalforum.ru/index.php?topic=395.0.

Fedorov, Ivan. "Belcanto.ru." Accessed September 23, 2014. http://www.belcanto.ru/goldenveiser.html.

Haan, Wim de. "Nikolai Kapustin: Pianist and Composer." Accessed June 30, 2014. http://www.nikolai-kapustin.info.

Ivanov, Osip. “Oleg Lundstrem Jazz Orchestra.” Accessed September 21, 2014. http://www.lundstrem-jazz.ru/eng/history.php.

Rijen, Onno van. "Nikolai Kapustin.” Accessed September 13, 2014. http://home.wanadoo.nl/ovar/kapustin.htm.

“Russkii Portal.” Accessed January 15, 2015. http://www.opoccuu.com/280711.htm.

\section{Additional Sources}

Nikolai Kapustin, interview by Yana Tyulkova, December 27, 2013.

Nikolai Kapustin, interview by Yana Tyulkova, July 9, 2014.

Nikolai Kapustin, interview by Yana Tyulkova, December 27, 2014.

\section{Musical Score}

Kapustin, Nikolai. Piano Sonata No. 3, Op. 55. Mainz, Germany: Schott Edition, 2014. 


\section{Appendix A}

Chart 1: Twenty Piano Sonatas - General Information

\begin{tabular}{|c|c|c|}
\hline Decades & Numbers of Sonatas & Total Sonatas \\
\hline 1980's & No. 1, No. 2 & 2 \\
1990's & No. 3- No. 10 & 8 \\
2000's & No. $11-$ No. 18 & 8 \\
2010's & No. 19, No. 20 & 2 \\
\hline
\end{tabular}


Chart 2: Twenty Piano Sonatas - Detailed Information

\begin{tabular}{|c|c|c|c|c|c|c|}
\hline Sonata & Opus & Year & Movements & Length & Nickname & Dedication \\
\hline Sonata No. 1 & Op. 39 & 1984 & 4 & $18: 17$ & $\begin{array}{l}\text { Sonata - } \\
\text { Fantasia }\end{array}$ & \\
\hline Sonata No. 2 & Op. 54 & 1989 & 4 & $22: 23$ & & \\
\hline Sonata No. 3 & Op. 55 & 1990 & 1 & $15: 19$ & & \\
\hline Sonata No. 4 & Op. 60 & 1991 & 3 & $12: 27$ & & \\
\hline Sonata No. 5 & Op. 61 & 1991 & 3 & $11: 57$ & & \\
\hline Sonata No. 6 & Op. 62 & 1991 & 3 & $13: 15$ & & \\
\hline Sonata No. 7 & Op. 64 & 1991 & 4 & $20: 46$ & & \\
\hline Sonata No. 8 & Op. 77 & 1995 & 1 & $13: 26$ & & \\
\hline Sonata No. 9 & Op. 78 & 1995 & 3 & $16: 34$ & & \\
\hline Sonata No. 10 & Op. 81 & 1996 & 3 & $12: 33$ & & \\
\hline Sonata No. 11 & Op. 101 & 2000 & 3 & $17: 26$ & Twickenham & \\
\hline Sonata No. 12 & Op. 102 & 2001 & 2 & $12: 22$ & & \\
\hline Sonata No. 13 & Op. 110 & 2003 & 4 & $16: 22$ & & \\
\hline Sonata No. 14 & Op. 120 & 2004 & 3 & $14: 50$ & & \\
\hline Sonata No. 15 & Op. 127 & 2005 & 1 & $23: 15$ & Fantasia quasi & \\
\hline Sonata No. 16 & Op. 131 & 2006 & 3 & $14: 23$ & & \\
\hline Sonata No. 17 & Op. 134 & 2008 & 3 & $16: 00$ & & Vito \\
\hline Sonata No. 18 & Op. 135 & 2008 & 3 & $15: 08$ & & \\
\hline Sonata No. 19 & Op. 143 & 2011 & 4 & $17: 44$ & & $\begin{array}{l}\text { Alexei } \\
\text { Volodin }\end{array}$ \\
\hline Sonata No. 20 & Op. 144 & 2011 & 3 & $14: 48$ & & \\
\hline
\end{tabular}


Chart 3: Three Parts of Piano Sonata No. 3, Op. 55

\begin{tabular}{|c|c|c|c|c|}
\hline Part & Measures & $\begin{array}{c}\text { Number of } \\
\text { measures }\end{array}$ & Timing & Length \\
\hline Part I & $1-158$ & 158 & $0: 00-7: 11$ & $7: 11$ \\
Part II & $159-196$ & 38 & $7: 12-10: 26$ & $3: 14$ \\
Part III & $197-387$ & 191 & $10: 27-15: 12$ & $4: 45$ \\
\hline
\end{tabular}

Chart 4: Sonata No. 3 Part I - Form

\begin{tabular}{|l|l|c|c|c|}
\hline \multicolumn{1}{|c|}{ Part I: Sections } & Measures & $\begin{array}{c}\text { Number of } \\
\text { measures }\end{array}$ & Timing & Length \\
\hline Exposition & $1-70$ & 70 & $0: 00-4: 28$ & $4: 28$ \\
Theme A1 & $1-20$ & 20 & & \\
Theme A2 & $21-30$ & 10 & & \\
Theme A3 & $31-42$ & 12 & \\
Theme B & $43-70$ & 28 & $3: 50-3: 55$ & $0: 05$ \\
Quote "Dies Irae" & $60-61$ & 2 & $4: 29-5: 48$ & $1: 19$ \\
Development & $71-117$ & 47 & & \\
Theme A1, Theme A2 & & & $5: 49-6: 44$ & $0: 55$ \\
material & $118-150$ & 33 & & \\
& $118-131$ & 14 & $6: 25-6: 35$ & $0: 10$ \\
"Mirror" Recapitulation & $132-134$ & 3 & & \\
Theme B & $135-150$ & 16 & $6: 45-7: 11$ & $0: 26$ \\
Theme A1 & $139-144$ & 6 & & \\
Theme A2 & & 8 & & \\
Theme C & $151-158$ & & & \\
Coda & & & & \\
Theme A1 material & & & & \\
\hline
\end{tabular}


Chart 5: Sonata No. 3 Part II - Form

\begin{tabular}{|l|c|c|c|c|}
\hline \multicolumn{1}{|c|}{ Part II: Themes } & Measures & $\begin{array}{c}\text { Number of } \\
\text { measures }\end{array}$ & Timing & Length \\
\hline Introduction & $159-160$ & 2 & $7: 12-7: 24$ & $0: 12$ \\
Theme C & $161-172$ & 12 & $7: 25-8: 38$ & $1: 13$ \\
Theme A1 & $162.4-164.3$ & 1.3 & $7: 34-7: 43$ & $0: 09$ \\
& $170.4-172.2$ & 1.2 & $8: 23-8: 36$ & $0: 13$ \\
Theme A2 & $173-178$ & 6 & $8: 39-9: 00$ & $0: 21$ \\
Theme B & $179-191$ & 13 & $9: 01-10: 04$ & $1: 03$ \\
Theme C & $192-196$ & 5 & $10: 05-10: 26$ & $0: 21$ \\
\hline
\end{tabular}


Chart 6: Sonata No. 3 Part III - Form

\begin{tabular}{|c|c|c|c|c|}
\hline Part III: Sections & Measures & $\begin{array}{c}\text { Number of } \\
\text { measures }\end{array}$ & Timing & Length \\
\hline Exposition & $197-236$ & 40 & $10: 27-11: 23$ & $0: 56$ \\
\hline Introduction & $197-200$ & 4 & & \\
\hline Theme C & $201-216.1$ & 15 & & \\
\hline Theme D & $216.2-236$ & 21 & & \\
\hline Development & $237-316$ & 80 & $11: 24-13: 27$ & $2: 03$ \\
\hline Theme $\mathrm{C}$ material & $237-244.3$ & & & \\
\hline Transition 1 & 244.4-251.1 & & & \\
\hline Theme $\mathrm{C}$ material & $251.2-275.3$ & & & \\
\hline Theme A1 & $255.3-260.1$ & & & \\
\hline Transition 2 & $275.4-279.3$ & & & \\
\hline Theme $\mathrm{C}$ material & 279.4-291 & & & \\
\hline Transition 3 & $292-295$ & & & \\
\hline Theme $\mathrm{C}$ material & $296-316$ & & & \\
\hline Recapitulation & $317-352$ & 36 & $13: 28-14: 21$ & $0: 53$ \\
\hline Introduction & $317-320$ & 4 & & \\
\hline Theme C & $321-332$ & 12 & & \\
\hline Theme D & $333-352$ & 20 & & \\
\hline Coda & & & & \\
\hline Theme $\mathrm{C}$ material & $353-387$ & 35 & $14: 22-15: 12$ & $0: 50$ \\
\hline
\end{tabular}


Chart 7: Sonata No. 3 Part I - Texture, Rhythm, Tonality, and Tempo Changes

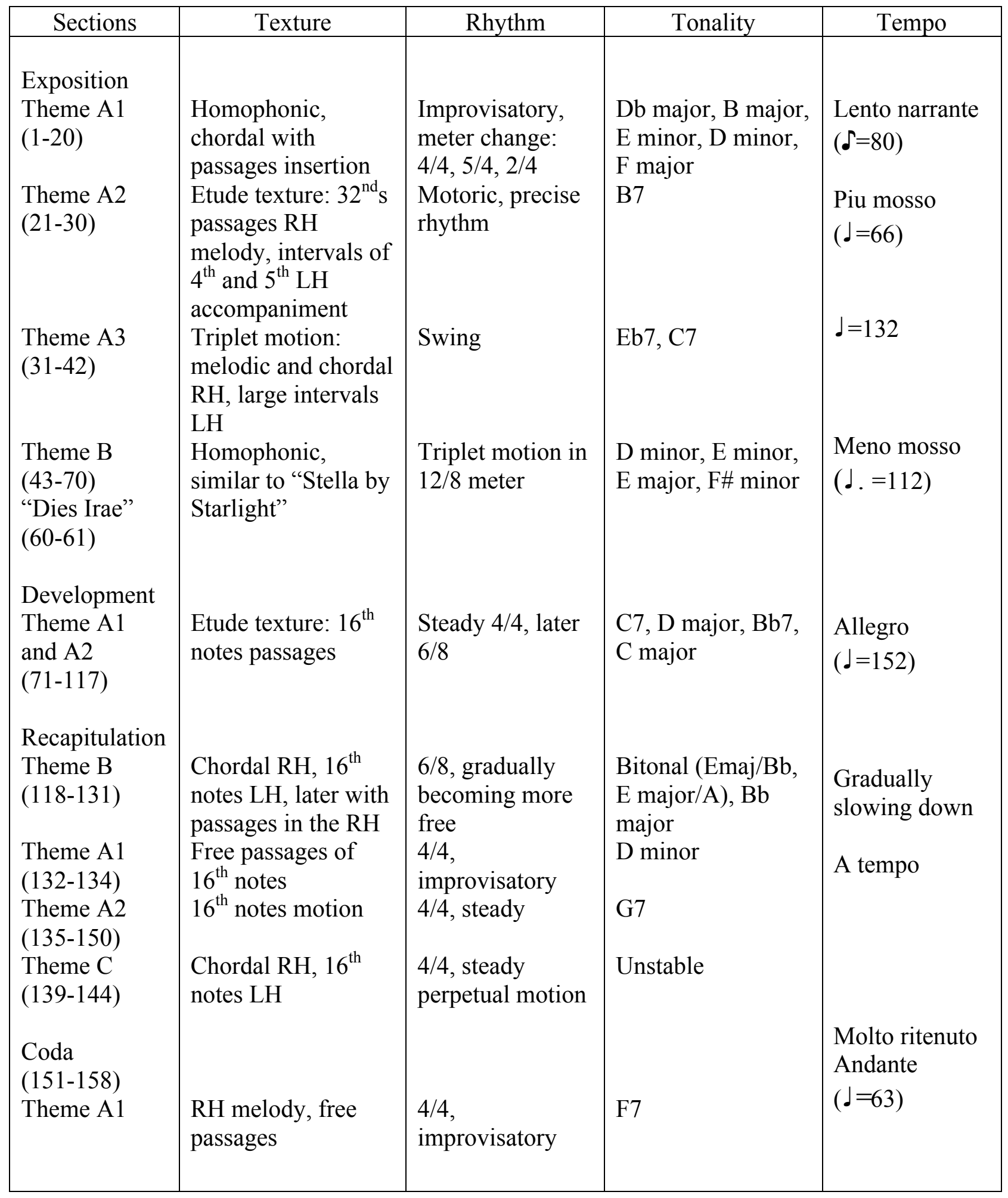


Chart 8: Sonata No. 3 Part II - Texture, Rhythm, Tonality, and Tempo Changes

\begin{tabular}{|c|c|c|c|c|}
\hline Sections & Texture & Rhythm & Tonality & Tempo \\
\hline $\begin{array}{l}\text { Introduction } \\
(159-160)\end{array}$ & Chordal & $4 / 4$, steady & E minor & $\operatorname{Largo}(d=50)$ \\
\hline $\begin{array}{l}\text { Theme C } \\
(161-172)\end{array}$ & $\begin{array}{l}\text { Contrapuntal } \\
\text { four-voice } \\
\text { texture with } \\
\text { insertion of } \\
\text { chordal texture, } \\
8^{\text {th }} \text { notes motion }\end{array}$ & & D minor & \\
\hline $\begin{array}{l}\text { Theme A1 } \\
\text { (162.4-164.3) }\end{array}$ & $\begin{array}{l}\text { Inserted into the } \\
\text { texture of Theme } \\
\text { C (top voice) }\end{array}$ & & & \\
\hline $\begin{array}{l}\text { Theme A2 } \\
(173-178)\end{array}$ & $\begin{array}{l}\text { Motoric, similar } \\
\text { to Theme A2 in } \\
\text { Part } 1\end{array}$ & 4/4, steady & D7 & \\
\hline $\begin{array}{l}\text { Theme B } \\
(179-191.3)\end{array}$ & $\begin{array}{l}\text { Contrapuntal, } \\
\text { homophonic, } \\
\text { improvisatory } \\
\text { passages, chordal }\end{array}$ & $4 / 4,12 / 8$ & $\begin{array}{l}\text { E minor, D } \\
\text { major, Eb major, } \\
\text { E major, Gb } \\
\text { major, E minor }\end{array}$ & $\begin{array}{l}\text { Cantabile } \\
(\downarrow .=\rfloor)\end{array}$ \\
\hline $\begin{array}{l}\text { Theme C } \\
(191.4-196)\end{array}$ & Contrapuntal & $4 / 4$ & $\begin{array}{l}\text { Unstable, ends } \\
\text { on } \mathrm{Bb} \text { (triton to } \\
\mathrm{E})\end{array}$ & \\
\hline
\end{tabular}


Chart 9: Sonata No. 3 Part III - Texture, Rhythm, Tonality, and Tempo Changes

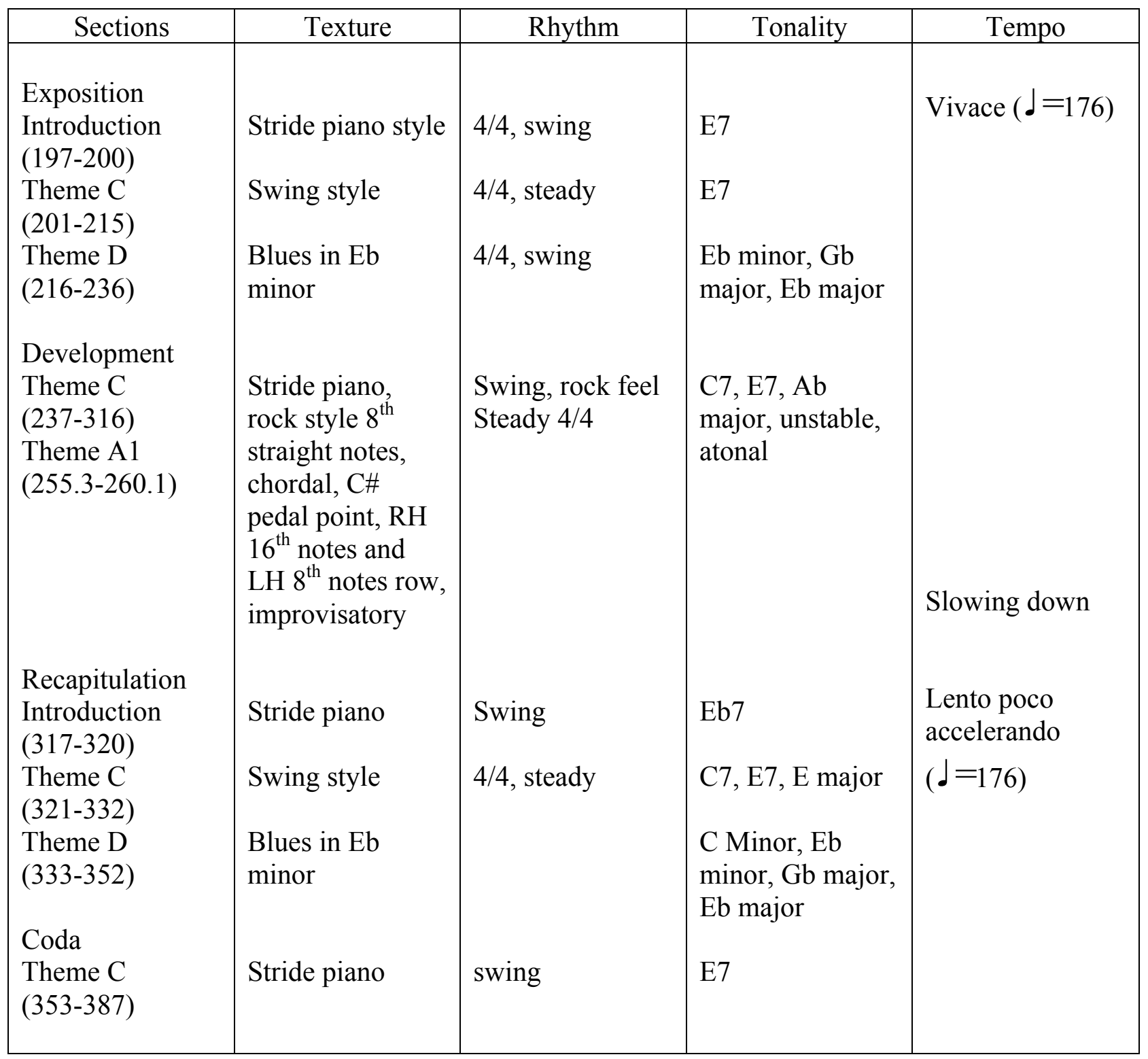


Appendix B

List of Works

Op. 1: Concertino for Piano and Orchestra (1957)

Op. 2: Concerto for Piano and Orchestra No. 1 (1961)

Op. 3: Variation for Piano and Big Band (1962)

Op. 4: Chorale and Fugue for Orchestra (1962)

Op. 5: Piece for Trumpet and Orchestra (1962)

Op. 6: "Rose-Marie" Fantasia for Orchestra (1963)

Op. 7: Fantasia on Three Children's Songs for Orchestra (1963)

Op. 8: Toccata for Piano and Orchestra (1964)

Op. 9: "The Trial" for Orchestra (1966)

Op. 10: "Big Band Sounds" for Orchestra (1966)

Op. 11: "Estacade" for Big Band (1966)

Op. 12: "Aquarium Blues" for Big Band (1967)

Op. 13: Intermezzo for Piano and Orchestra (1968)

Op. 14: Concerto for Piano and Orchestra No. 2 (1974)

Op. 15: "The Forest Story" for Orchestra (1972)

Op. 16: Nocturne for Piano and Orchestra (1972)

Op. 17: Three Pieces for Orchestra (1972)

Op. 18: Four Pieces for Instrumental Ensemble (1973)

Op. 19: Etude for Piano and Orchestra (1974)

Op. 20: Nocturne for Piano and Orchestra (1974)

Op. 21: Minuet for Big Band (1974)

Op. 22: Piece for Five Saxophones and Orchestra (1975)

Op. 23: "Enigma" for Big Band (1975)

Op. 24: March for Orchestra (1975)

Op. 25: Concert Rhapsody for Piano and Orchestra (1976)

Op. 26: "Sunrise" for Piano (1976)

Op. 26a: "Sunrise" for Orchestra (1976)

Op. 27: Fantasia for Jazz Quartet (1976)

Op. 28: Suite in the Old Style for Piano (1977)

Op. 29: Scherzo for Piano and Orchestra (1978)

Op. 30: Two-movement Concerto for Orchestra (1980)

Op. 31: Elegy for Orchestra (1980)

Op. 32: "The Wind from the North" for Orchestra (1981)

Op. 33: Piece for Two Pianos and Orchestra (1982)

Op. 34: "Meridian" for Orchestra (1982)

Op. 35: "Closed Curve" for Orchestra (1982)

Op. 36: Toccatina for Piano (1983)

Op. 37: "The Pleasant Meeting” for Orchestra (1983)

Op. 38: "Presentiment" for Orchestra (1983)

Op. 39: Piano Sonata No.1 "Quasi una Fantasia" for Piano (1984)

Op. 40: Eight Concert Studies for Piano (1984)

Op. 41: Variations for Piano (1984) 
Op. 42: "Rush Hour" for Ensemble (1985)

Op. 43: "An April Day" for Ensemble (1985)

Op. 44: "The Morning” for Ensemble (1985)

Op. 45: "Motive Force" for Piano (1985)

Op. 46: "Big Band Sounds" for Piano (1986)

Op. 47: "Contemplation" for Piano (1987)

Op. 48: Concerto for Piano and Orchestra No. 3 (1985)

Op. 49: Sinfonietta for Orchestra (1987)

Op. 50: Concerto for Alto Saxophone and Orchestra (1987)

Op. 51: Overture for Big Band (1987)

Op. 52: "Intrada" for Big Band (1988)

Op. 53: Twenty-Four Preludes for Piano (1988)

Op. 54: Piano Sonata No. 2 (1989)

Op. 55: Piano Sonata No. 3 (1990)

Op. 56: Concerto for Piano and Orchestra No. 4 (1989)

Op. 57: Chamber Symphony for Chamber Orchestra (1990)

Op. 58: Andante for Piano (1990)

Op. 59: Ten Bagatelles for Piano (1991)

Op. 60: Piano Sonata No. 4 (1991)

Op. 61: Piano Sonata No. 5 (1991)

Op. 62: Piano Sonata No. 6 (1991)

Op. 63: Sonata for Cello and Piano No. 1 (1991)

Op. 64: Piano Sonata No.7 (1991)

Op. 65: Berceuse for Piano (1991)

Op. 66: Three Impromptus for Piano (1991)

Op. 67: Three Etudes for Piano (1992)

Op. 68: Five Etudes in Different Intervals for Piano (1992)

Op. 69: Sonata for Viola and Piano (1992)

Op. 70: Sonata for Violin and Piano (1992)

Op. 71: Capriccio for Piano (1992)

Op. 72: Concerto for Piano and Orchestra No. 5 (1993)

Op. 73: Ten Inventions for Piano (1993)

Op. 74: Concerto for Piano and Orchestra No. 6 (1993)

Op. 75: Humoresque for Piano (1994)

Op. 76: Concerto for Double Bass and Symphony Orchestra (1994)

Op. 77: Piano Sonata No. 8 (1995)

Op. 78: Piano Sonata No. 9 (1995)

Op. 79: Piece for Sextet (1995)

Op. 80: Theme and Variations for Piano (1996)

Op. 81: Piano Sonata No. 10 (1996)

Op. 82: Twenty-four Preludes and Fugues for Piano (1997)

Op. 83: Impromptu for piano (1997)

Op. 84: Sonata for Cello and Piano No. 2 (1997)

Op. 85: Concerto for Cello and Orchestra (1997)

Op. 86: Trio for Flute, Cello and Piano (1998)

Op. 87: Seven Polyphonic Pieces for Piano Left Hand (1998) 
Op. 88: String Quartet (1998)

Op. 89: Piano Quintet (1998)

Op. 90: Concerto for Eleven Instruments (1998)

Op. 91: Divertissement for Two Flutes, Cello and Piano (1998)

Op. 92: Suite for Piano (1999)

Op. 93: Introduction and Scherzino for Cello Solo (1999)

Op. 94: Ballad for Piano (1999)

Op. 95: Scherzo for Piano (1999)

Op. 96: Elegy for Cello and Piano (1999)

Op. 97: Burlesque for Cello and Piano (1999)

Op. 98: "Nearly Waltz" for Cello and Piano (1999)

Op. 99: Duet for Alto Saxophone and Cello (1999)

Op. 100: Sonatina for Piano (2000)

Op. 101: Piano Sonata No. 11 "Twickenham" (2000)

Op. 102: Piano Sonata No. 12 (2001)

Op. 103: Concerto No. 2 for Cello and String Orchestra (2002)

Op. 104: Concert for Two Pianos and Percussion (2002)

Op. 105: Concert for Violin, Piano and String Orchestra (2002)

Op. 106: Suite for Viola, Alto Saxophone, Piano and Bass (2002)

Op. 107: Variations on "Sweet Georgia Brown" for Viola, Alto Saxophone, Piano and Bass (2002)

Op. 108: Paraphrase on a Theme of Paul Dvoyrin for Piano (2003)

Op. 109: "There is Something Behind That" for Piano (2003)

Op. 110: Piano Sonata No. 13 (2003)

Op. 111: "Gingerbread Man" for Piano (2003)

Op. 112: "End of the Rainbow" for Piano (2003)

Op. 113: "Wheel of Fortune" for Piano (2003)

Op. 114: "No Stop Signs" for Piano (2003)

Op. 115: Fantasia for Piano (2003)

Op. 116: Rondoletto for Piano (2003)

Op. 117: "Spice Island" for Piano (2003)

Op. 118: Paraphrase on "Aquarela do Brasil" by Ary Barroso for Piano (2003)

Op. 119: "Nothing to Lose" for Piano (2004)

Op. 120: Piano Sonata No. 14 (2004)

Op. 121: "Vanity of Vanities" for Piano (2004)

Op. 122: Two Etude-like Trinkets for Piano (2004)

Op. 123: Paraphrase on "Blue Bossa" by Kenny Dorham for Piano (2004)

Op. 124: Suite for Cello Solo (2004)

Op. 125: Sonata for Flute and Piano (2004)

Op. 126: Divertissement in Four Movements for Violin, Cello and Piano (2005)

Op. 127: Piano Sonata No. 15 (Fantasia quasi Sonata) (2005)

Op. 128: Introduction and Rondo for Piano Solo (2006)

Op. 129: Paraphrase on Dizzy Gillespie's "Manteca" for Two Pianos, Four Hands (2006)

Op. 130: Countermove for Piano Solo (2006)

Op. 131: Piano Sonata No. 16 (2006)

Op. 132: String Quartet No. 2 (2007) 
Op. 133: Six Little Preludes for Piano Solo (2007)

Op. 134: Piano Sonata No. 17 (2008)

Op. 135: Piano Sonata No. 18 (2008)

Op. 136: Piano Trio No. 1 for Violin, Cello and Piano (2009)

Op. 137: Good Intention for Piano Solo (2009)

Op. 138: Sleight of Hand for Piano Solo (2009)

Op. 139: Holy Cow for Piano Solo (2009)

Op. 140: Freeway for Piano Solo (2009)

Op. 141: Violin Concerto (2009)

Op. 142: Piano Trio No. 2 for Violin, Cello and Piano (2010)

Op. 143: Piano Sonata No. 19 (2011)

Op. 144: Piano Sonata No. 20 (2011)

Op. 145: Triptych for Two Pianos, Four Hands (2012)

Op. 146: Capriccio for Piano, Four Hands (2012)

Op. 147: Concerto for Piano and orchestra No. 1 (2nd edition) (2012)

Op. 148: Dialogue for Solo Piano (2013)

Op. 149: Etude Courte mais Transcendante pour Piano (2013)

Op. 150: String Quartet "Rondo Frivole" pour quatuor à cordes (2013)

Op. 151: Nobody is Perfect for Piano Solo (2013)

Op. 152: A Pianist in Jeopardy for Piano Solo (2013)

Op. 153: Wandering for Piano Solo (2013)

Op. 154: Piece for String Quartet “The Last Attempt" (2014)

Op. 155: Allegro for Piano Trio (2014)

Op. 156: A Little Duo for Flute \& Cello (2014)

Op. 157: Curiosity for Piano Solo (2015) 